\title{
（25） 混鉄車熱間補修装置の開発改善について
}

住友金属工業㑣 鹿島製鉄所 橋尾守規 広木伸好 相馬正幸 ○高橋 明 総合技術研究所 池宮洋行

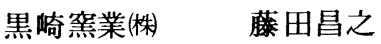

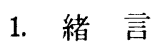

混鉄車の师内観察および吹付補修を機械化し、耐火物のコストダウンを図るため、コンピューター制 御による熱間補修装置の開発を進めてきた。今回、テスト装置 ${ }^{1)}(1$ 号機)に種々の改良を加えた本格装 置の 2 号機を導入し、操業を開始したのでその設備概要および熱間吹付材 ${ }^{2}$ の改善状況につけて報告する。

\section{2. 熱間補修装置の開発}

Fig.1に 2 号機の概要を示すが、1 号機と比較して、 C P U のレベルアップ等を図り、性能を向上させている。

(1) 観察可能 M A X温度： $9000 \mathrm{C} \rightarrow 100000$

(2) 吹付 M A X速度： $20 \mathrm{~kg} /$ 分 $\rightarrow 50 \mathrm{~kg} /$ 分

（3）吹付場所の設定方法：番地指定 $\rightarrow$ 任意選択

(4) 熱間補修時間 :

約 5.5 時間 $/$ 車

3. 熱間吹付材の改善

2 号機稼働当初は、高 $\mathrm{Al}_{2} \mathrm{O}_{3}$ 質の吹付材を適用したが、

耐用が低く剥離・損耗が著しかった。実炉の使用後サン プル (Fig. 2 参照) を解析調查した結果、れんが付着ス ラグの影響を受け、吹付材の稼働面および背面の双方か ら損耗が進行すること等が判明した。この対策として、吹付材 の耐食性向上およびスラグ浸入防止のため $\mathrm{SiC}$ の添加、また、 接着性の強化を図るため、適正な硬化時間を有するバインダーの 開発等を実施した。改善後の吹付材品質例をTable 1に示す。

\section{4. 実炉適用結果}

Fig. 3 およびFig. 4 に示すように熱間吹付による部分補修と 冷間吹付の組合せにより、混鉄車寿命は $20 \%$ 向上し、このと きの耐火物コストはトータル19\%の低減になった。
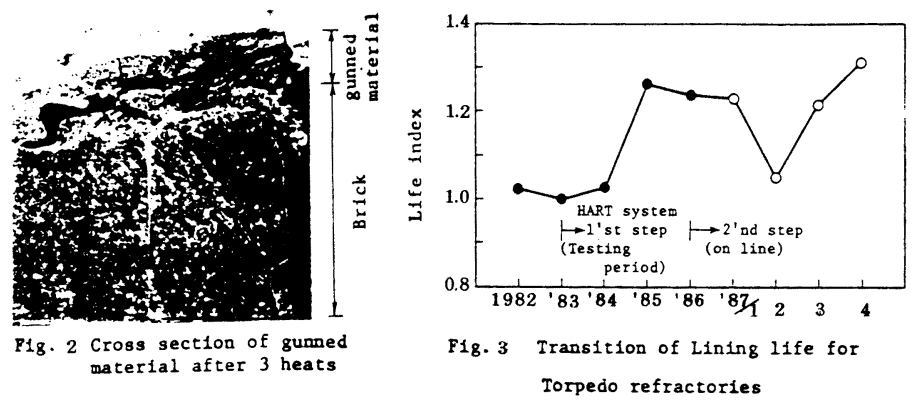

〈参考文献〉
1) 小島ら：耐火物 $36[10] 564 \sim 566(1984)$
2) 戸畸ら：耐火物 $37[12] 723 \sim 726(1985)$

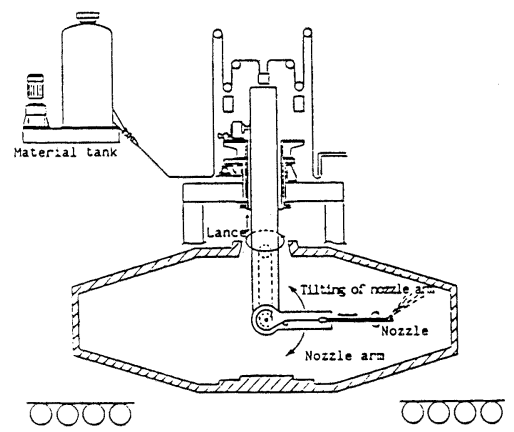

F1g.1 Outline of Gunning equipment

Table 1 Typical property of gunning material

\begin{tabular}{|c|c|}
\hline Binder type & A \\
\hline $\begin{array}{l}\text { Chemical composition (z) } \\
\qquad \begin{array}{c}\mathrm{Al}_{2} \mathrm{O}_{3} \\
\mathrm{SiO}_{2} \\
\mathrm{SiC}+\mathrm{C}\end{array}\end{array}$ & $\begin{array}{r}72.2 \\
8.0 \\
13.5\end{array}$ \\
\hline $\begin{array}{l}\text { Apparent porosity }(\%) \\
\text { after } 1500^{\circ} \mathrm{C} \times 3 \mathrm{hr} . \\
\text { Bulk density } \\
\quad \text { after } 1500^{\circ} \mathrm{C} \times 3 \mathrm{hr} . \\
\left.\text { M.O.R (kgf } / \mathrm{cm}^{2}\right) \\
\quad \text { after } 1500^{\circ} \mathrm{C} \times 3 \mathrm{hr} . \\
\text { Linear expansion } \\
\text { after } 1500^{\circ} \mathrm{C} \times 3 \mathrm{hr} .\end{array}$ & $\begin{array}{l}35.8 \\
2.19 \\
36 \\
+0.36\end{array}$ \\
\hline $\begin{array}{l}\text { Max. grain size (mm) } \\
\text { Grain size } \\
\text { distribution (z) }<74 \mu\end{array}$ & $\begin{array}{l}2.8 \\
38\end{array}$ \\
\hline
\end{tabular}

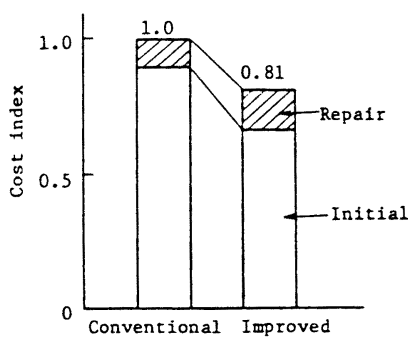

Fig. 4 Comparison of Cost index for Torpedo refractories 
' $87-\mathrm{S} 988$

$(252)$

\section{窒化物含有 $\mathrm{Al}_{2} \mathrm{O}_{3}-\mathrm{SiC}-\mathrm{C}$ 算れんかの開発 \\ (溶鉄予備処理用耐火物の開発一 3 )}

（株）神戸製鋼所 加古川製鉄所 副島利行 小林潤吉 大島隆三 0 大手 彰 品川白練瓦（株）

田畑勝弘 市川健治 藤原禎一

\section{1. 緒 言}

加古川製鉄所では、従来の混銑車脱硫処理に加え'8 5 年 1 月より溶銧予備処理プロセス（TOP：

Torpedo Oxidization Process）を稼動させた。本プロセスは、混銑車での脱珪処理、脱燐処理より なる。現在混銑車内張り而火物は、天井部に焼成 $\mathrm{Al}_{2} \mathrm{O}_{3}$ 質、スラグライン部および溶銑部に $\mathrm{Al}_{2} \mathrm{O}_{3}-\mathrm{SiC}$ 一 C 質れんがをライニングしている。今回窒化物を含有した $\mathrm{Al}_{2} \mathrm{O}_{3}-\mathrm{SiC}-\mathrm{C}$ 質れんがを開発し、実炣テ ストを行ったのでその結果を報告する。

Table 1 Properties of Test Bricks

\section{2. ラボテスト結果}

䇪化物としては、 $\mathrm{Si}_{3} \mathrm{~N}_{4}, \mathrm{AlN}$ を検討したが、 AlN は水溶性であるためAION で添加した。Table ー 1 亿試作れんがの品質を示す。れんが $\mathrm{A}$ はベー スの $\mathrm{Al}_{2} \mathrm{O}_{3}-\mathrm{SiC}-\mathrm{C}$ 質れんがであり現在スラグラ インに使用している。Aれんがをべースとし $\mathrm{SiC}$ を $\mathrm{Si}_{3} \mathrm{~N}_{4}$ 亿置換した B，C，D れんがおよび $\mathrm{Al}_{2} \mathrm{O}_{3}$

\begin{tabular}{|c|c|c|c|c|c|c|c|}
\hline & $\mathrm{A}$ & $\mathrm{B}$ & $\mathrm{C}$ & D & $E$ & $F$ & G \\
\hline \multicolumn{8}{|l|}{ Chemical Composition ( $2 / 3)$} \\
\hline $\mathrm{Al}_{2} \mathrm{O}_{\mathrm{B}}$ & 66 & 66 & 66 & 66 & 59 & 39 & 19 \\
\hline AlON & - & - & - & - & 7 & 27 & 47 \\
\hline $\mathrm{Si}_{3} \mathrm{~N}_{4}$ & - & 5 & 10 & 15 & - & - & - \\
\hline $\mathrm{Sic}+\mathrm{C}$ & 28 & 23 & 18 & 13 & 28 & 28 & 28 \\
\hline Apparent Porosity $\quad(2 / 3)$ & 7.5 & 6.7 & 11.4 & 9.3 & 7.4 & 8.6 & 8.0 \\
\hline Bulk Density $\quad\left(\mathrm{g} / \mathrm{cm}^{\theta}\right)$ & 3.01 & 3.04 & 2.88 & 2.93 & 2.97 & 2.92 & 2.90 \\
\hline $\begin{array}{l}\text { Crushing Strength } \\
\qquad\left(\mathrm{kgf} / \mathrm{cm}^{2}\right)\end{array}$ & 470 & 485 & 390 & 650 & 480 & 380 & 380 \\
\hline Remarks & $\begin{array}{l}\text { Ordi- } \\
\text { nary }\end{array}$ & Add it & on 0 & $\mathrm{Si}_{3} \mathrm{~N}$ & Add & on & Alar \\
\hline
\end{tabular}
をAIONに置換した E , F，Gれんがを試作した。。

Fig.1亿耐スラグ性、Fig.2亿耐熱スポーリング性テス トの結果を示す。 $\mathrm{Si}_{3} \mathrm{~N}_{4}$ 添加により耐スラグ性は低下する が添加量増加により低下量は減少する。而熱スポーリング 性は $\mathrm{Si}_{3} \mathrm{~N}_{4}$ 添加量に比例して向上する。AlON 添加の場合 耐スラグ性は向上するが添加量には最適值があり、7\%添

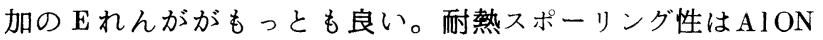
添加でやゃ低下するが添加量によらず一定である。てれら の結果より $\mathrm{Si}_{3} \mathrm{~N}_{4} 5 \%$ 添加のれんが B および $\mathrm{AlON} 7 \%$ 添 加のれんが $\mathrm{E}$ を実炬テストに供した。

\section{3. 実炉テスト状況}

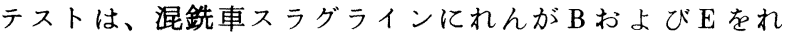
んが $\mathrm{A}$ と張り分けた。通銑量 $500^{\mathrm{KT}}$ 時の中間点検では、れ んが $\mathrm{A}$ に比較しれんが $\mathrm{B}$ は同等、れんが $\mathrm{E}$ はやや良好な結 果であり、スポーリングによるクラック発生もなく健全な 状態であった。

\section{4. まटめ}

溶銑予備処理用耐火物として $\mathrm{Si}_{3} \mathrm{~N}_{4}$ および $\mathrm{AlON}$ を添加

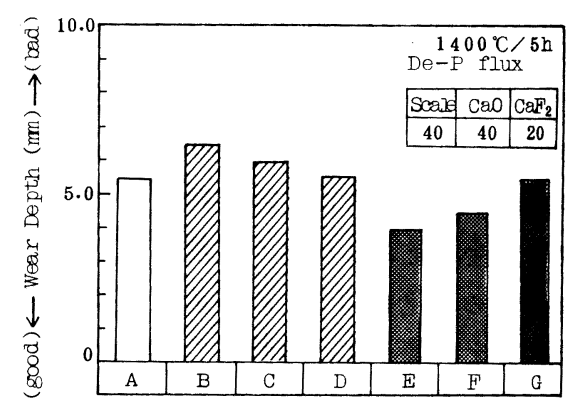

Fig.l Results of Slag Corrosion Test

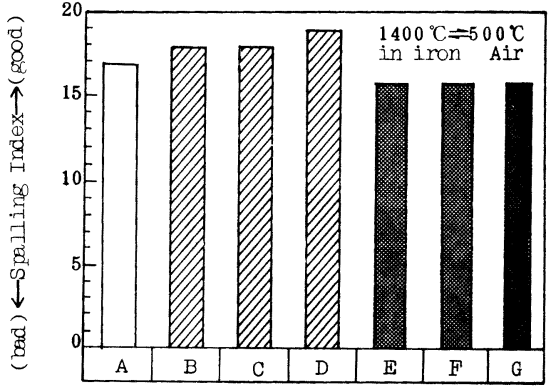

Fig. 2 Results of Thermal Spalling Test した $\mathrm{Al}_{2} \mathrm{O}_{3}-\mathrm{SiC}-\mathrm{C}$ 質れんがを試作し、混銧車スラグラインでの張り分けテストを行った。中間点検 では、現状れんがに比べ $\mathrm{Si}_{3} \mathrm{~N}_{4}$ 添加品は同等、AlON 添加品は良好との結果を得た。

（文献） 1）副島ら：鉄と鋼，69(1983)S906

2) 副島ら：鉄と鋼，72(1986)\$150

3）副島ら：第22回精鍊用耐火物委員会分科会 (1987) 


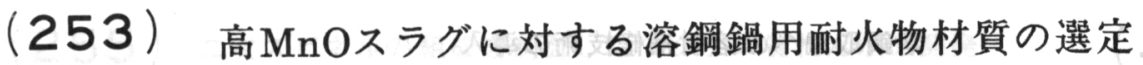

\author{
神戸製鋼所 鉄鋼技術センター ○佐藤哲郎 植村健一郎 \\ 神戸製鉄所杉本博司片桐行雄
}

1. 緒 言

神戸製鉄所においては鉛快削鋼の製造を従来の普通造塊法から,ブルーム連鉡プロセスに変更し，被 削性等の品質の維持と歩留向上による製造コストの低減に大きな効果をあげているが, AISI-12L14系快 削鋼に代表されるA， Si 無添加一高Mn鋼を溶製する場合には，高MnO スラグによる一般壁 $\mathrm{Al}_{2} \mathrm{O}_{3}-\mathrm{C} れ$ んがの溶損が增大し，工程の安定化と耐火物コストの低減をはかるうえで大きな問題となった。そこで， 実鍋耐火物の損傷形熊の調查と若干の基礎実験にもとつてい高 $\mathrm{nn} 0$ スラグによる耐火物の損傷機構を推 定するとともに，耐火物材質の改善を進め，実機に適用して良好な結果が得られたので報告する。 な招，12L14 系快削鋼のスラグ組成を炭素鋼と比較して表 1 に示した。

\section{2. 実鍋使用後れんがの調查}

使用後の $\mathrm{Al}_{2} \mathrm{O}_{3}-\mathrm{C}$ れんがの顕微鏡組織を写真 1 に示した。アルミナ骨材においては表面からの溶損と スラグの浸透による粒の分離が同時に進行しており,一方, マトリックス部においては稼動面から数 mm

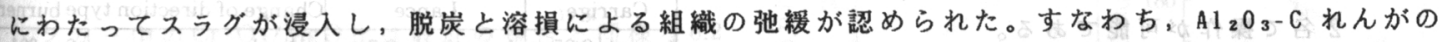
損傷は，高Mn0 スラグによるアルミナ粒の溶損と脱炭速度の增大，およびスラグ浸透部からの剥離が原 因と考えられる。

\section{3. 基礎実験}

使用後れんがの調查 結果にもとつきスうグ と耐火物の反応性を調 查した。まず,スラグ Phot 1. Micro stracture of Used brick 中のMn0の影響については図1に示したとおりであ ク，れんがの溶損は（MnO）にほほ比例して增大して いる。次に，低 $\left(M_{\mathrm{n} 0} 0\right)$ スラクで效果の認められた $\mathrm{MgO}$ 添加の影響"については20\%添加してもさほど 効果の期待できないことが分った。

そこで, 表 2 に示した 5 種類のれんが材質につい てスラグ侵食テストをおこなったところ，不純物の $\mathrm{Si}_{2} \mathrm{O}_{2}$ を低減した材質で著しく耐スラグ侵食性の改善 が珰められた。

4.まとめ : 材質 $\mathrm{E}$ を実鍋でテストしたところ, 溶損量が $10 \mathrm{~mm} / \mathrm{ch}$ より $1 \sim 2 \mathrm{~mm} / \mathrm{ch}$ に減少した。

Table 1. Slag composition (\%)

\begin{tabular}{|l|c|c|c|c|c|}
\hline & $\mathrm{C} / \mathrm{S}$ & $\mathrm{Al}_{2} \mathrm{O}_{\mathbf{3}}$ & $\mathrm{Mg} 0$ & $\mathrm{Mn} 0$ & $\mathrm{~T} \cdot \mathrm{Fe}$ \\
\hline $12 \mathrm{~L} 14$ & 2.5 & 15 & 8 & 20 & 5 \\
Carbon steel & 3 & 15 & 10 & 0.2 & 0.1 \\
\hline
\end{tabular}

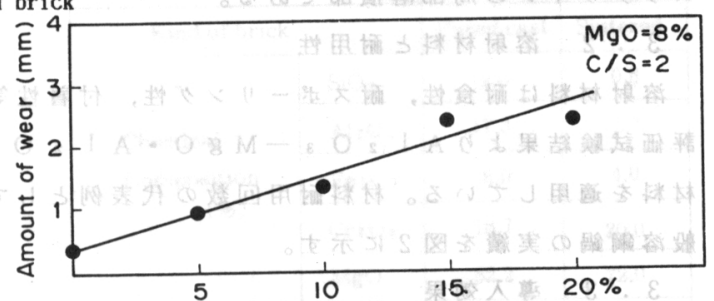

Fig. 1. (Mn0) VS. Amount of wear

Table 2. Properties of brick

\begin{tabular}{|c|c|c|c|c|c|c|c|}
\hline & \multirow{2}{*}{$\begin{array}{l}\text { Conven } \\
\text { tional }\end{array}$} & \multicolumn{5}{|c|}{ 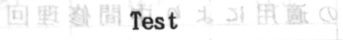 } \\
\hline & & & A & B. & C & D & E \\
\hline \multirow{3}{*}{ 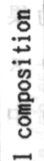 } & $\mathrm{Mg0} \%$ & 20 & 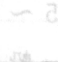 & 13 & 98 & 53.8 & 73.0 \\
\hline & $\mathrm{SiO}_{2}$ & 10.5 & 11 & & 0.5 & 2.0 & 2.5 \\
\hline & $\mathrm{SiC}$ & & 6 & & & & \\
\hline \multirow{2}{*}{ 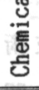 } & $\mathrm{Al}_{2} \mathrm{O}_{3}$ & 78.6 & 72 & 99.2 & & & \\
\hline & C & 4.8 & 6 & & & 36.0 & 17.5 \\
\hline \multicolumn{2}{|c|}{$\begin{array}{l}\text { Amount } \\
\text { of wear }\end{array}$} & 7.2 & 4.1 & 1.6 & 1.0 & 0.8 & 0.8 \\
\hline
\end{tabular}

参考文献 1）佐藤ら鉄と鋼，72（1986） \$153 


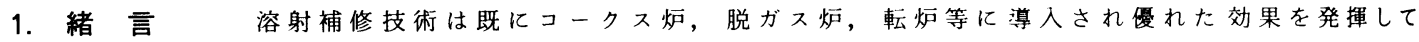
いる。今回，先に報告したオンライン試験結果をあとにして，当所第一製鋼工場の取鍋へ中間修理を減 少させ炉材コストの削減を図るため，昭和 60 年 11 月より実機を導入したので概要を報告する。

\section{2. 装置の概要と特徴}

図 1, 表 1 亿取鍋溶射装置の概要と主仕様を示す。 本装置の主な特徵は, 次の 3 点である。

1) 燃焼ガスはプロパン，酸素を使用し，溶射能 力は $5000 \mathrm{~kg} / \mathrm{h}$ である。

2) バーナーは角度可変式であり, 一種類で敷部 と側壁部の補修が可能である。

3) 装置の徹底したコンパクト化と自動化により 2 名で操作が可能である。

\section{3. 稼働状況}

\section{3 . 1 補修作業}

補修作業は工場内の取鍋メンテナンスピット内に水 平状態に傾動し，熱間で実施している。補修対象鍋は 一般溶鋼鍋，V A C 鍋，L F 鍋の全取鍋である。主な 補修箇所は羽口, 敷湯当り部であり, この他に側壁, スラグラインの局部溶損部である。

3 . 2 溶射材料之耐用性

溶射材料は耐食性，耐スポーリング性，付着性等の 評価試験結果より $\mathrm{Al}_{2} \mathrm{O}_{3}-\mathrm{M} \mathrm{g} \mathrm{O} \mathrm{O}_{3} \mathrm{Al}_{2} \mathrm{O}_{3}$ 系 材料を適用している。材料耐用回数の代表例として一 般溶鋼鍋の実績を図 2 亿示す。

\section{3 . 3 導入効果}

一般溶鋼鍋の中間修理実績を図 3 亿示す。溶射補修 の適用により中間修理回数は, 5 回から 3 回に減少し ている。乙れにより炬材有効使用率が向上し, 炬材コ スト指数において $15 \sim 20 \%$ の削減効果を得ている。 図4 は代表例として一般溶鋼鍋の炬材コスト指数を示 したあのである。溶射補修の適用により中間修理が減 少し，15\%のコスト削減を得ている。

4. 結言溶鋼取鍋へ溶射補修技術を適用した 結果, 羽口, 敷湯当り寿命が向上し, 中間修理回数の 減少による大幅な炬材削減効果を得ることができた。 <参考文献 $>$ 平櫛他：耐火物 37

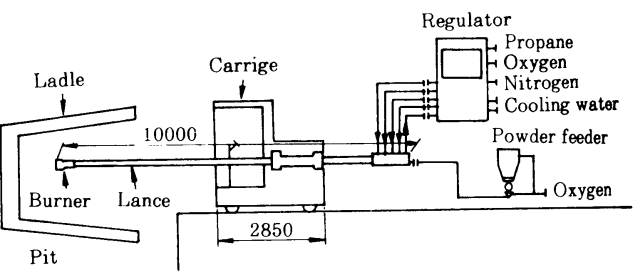

Fig. 1 Schematic view of equipment

Table 1 Specification of flame gunning equipment \begin{tabular}{|c|c|c|c|l|c|}
\hline \multicolumn{2}{|c|}{ Carrige } & \multicolumn{2}{c|}{ Lance } & Change of direction type burner \\
\hline Length & $2.85 \mathrm{~m}$ & Length & $8.7 \mathrm{~m}$ & Angle & $0 \sim 90^{\circ}$ \\
\hline Width & $1.90 \mathrm{~m}$ & Diameter & $\phi 170 \mathrm{~mm}$ & Powder feed rate & $500 \mathrm{k} / \mathrm{h}$ \\
\hline Weigth & $7.0 \mathrm{t}$ & Weight & $0.5 \mathrm{t}$ & Flow rate of propane & $150 \mathrm{H} / \mathrm{h}$ \\
\hline
\end{tabular}

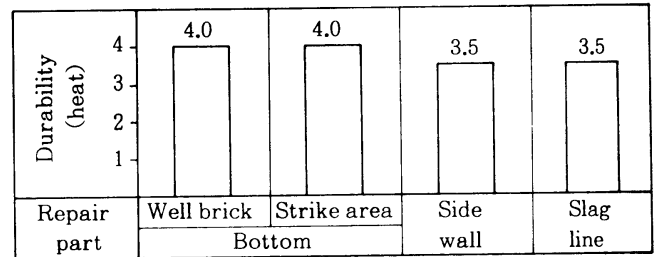

Fig. 2 Durability of flame gunning material

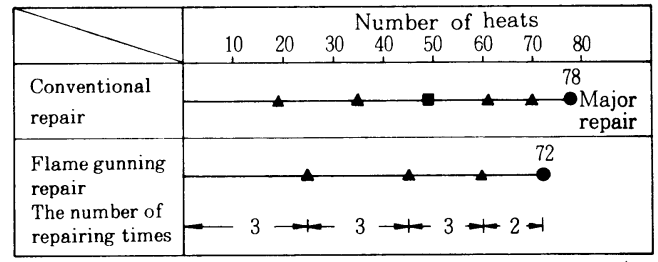

- Minor repair (well or strike area) Medium repair(well , bottm)

Fig. 3 Results of repair pattern

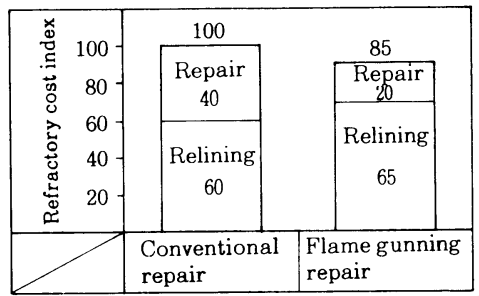

Fig. 4 Results of refractory cost index

$\left(\begin{array}{llll}1 & 9 & 8 & 5\end{array}\right)$ 


\section{（255） 二次スピネルの組成を制御したマグクロ質れんがの開発}

\begin{tabular}{|c|c|c|c|}
\hline 新 日鐵 (株) & 八幡製鐵所 & 島田康平 & 磯村福義 \\
\hline & & ○井上裕文 & 松尾三郎 \\
\hline
\end{tabular}

黒崎害業(株技術研究所多喜多一郎

\section{1. 緒 言}

八幡製鐵所の D H 槽底用内張りれんがは、従来マグ ク口質電鋳れんがを使用して来たがコスト削減の目的 でマグクロ質焼成れんがの使用を試みた。焼成れんが は、種々の改善を行なった結果実炉使用において良好 な成績を示したので報告する。

\section{2. マグクロ質焼成れんがの特徵}

$2-1$ 電融クリンカーの組成

電融マグクロクリンカ一はクリンカ一の耐食性 および生成する粒間複合二次スピネルの組成を高 融点にするための㭘討を行なった。使用したクリ ンカー中の $\mathrm{Cr}_{2} \mathrm{O}_{3} / \mathrm{MgO}$ 比は最近の報告と同様な 0.2 〜0.3を最適範囲として用いた。高周波誘導炉によ る耐食性調查から $\mathrm{Cr}_{2} \mathrm{O}_{3} / \mathrm{Al}_{2} \mathrm{O}_{3}+\mathrm{Fe}_{2} \mathrm{O}_{3}$ 成分の比が 2.3の電融マグクロクリンカーを用いた試作れんが が良好な耐食性を示した。（Fig. 1 亿示す)

$2-2$ 焼成れんがの熱間強度

D H 槽底用れんがとしての熱間強度向上対策は れんが形状の小型化と高温焼成によった。乙の結 果試作れんがは充填度が向上し熱間強度は従来の 電鋳れんがと同レベルまで向上した。（Fig. 2 に 示す）その品質は table 1 に示す。

\section{3. 実炉使用結果}

本開発の焼成れんがを八幡製鐵所第一、第三製 鋼工場の D H 槽底に適用した。Fig. 3 に示すよう に両工場とも従来品之比較し約 $20 \%$ の寿命延長が 達成でき、約 $15 \%$ のコスト削減が可能となった。

\section{4. 結 言}

本開発品であるマグク口質焼成れんがは、従来 の電鋳れんがと代替でき D H 槽底寿命の安定した 向上と大幅なコスト削減を可能にした。

参考文献 1)浅野他；耐火物、Na 2. vol. 39, 1987, P 3 2)平櫛； 耐火物、 NNa 2 , vol. 39,1987, P 37

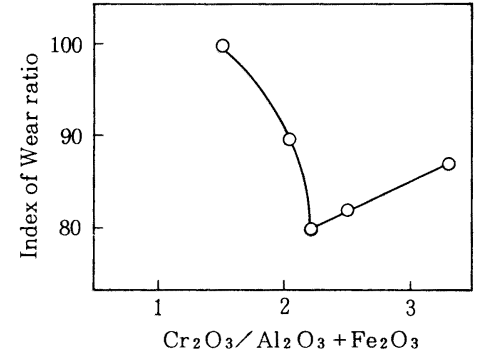

Fig. 1 Wear ratio on $\mathrm{Cr}_{2} \mathrm{O}_{3} / \mathrm{Al}_{2} \mathrm{O}_{3}+\mathrm{Fe}_{2} \mathrm{O}_{3}$ in clinker
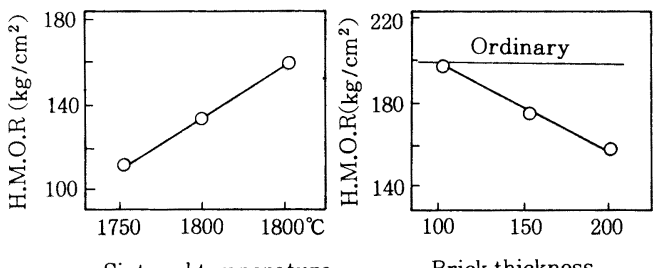

Sintered temperature

Brick thickness

Fig. 2 Relation between H.M.O.R of Sintered temperature and thickness by tesing furnace

\# Hot Modulus of Rupture

Table 1 Properties of test brick

\begin{tabular}{|c|c|c|c|}
\hline \multicolumn{2}{|c|}{} & Ordinary & $\begin{array}{l}\text { Improve- } \\
\text { ment }\end{array}$ \\
\hline \multicolumn{2}{|c|}{ Kind of brick } & Fused cast & Sintered \\
\hline \multirow{4}{*}{$\begin{array}{c}\text { Chemical } \\
\text { Composition } \\
(\%)\end{array}$} & $\mathrm{SiO}_{2}$ & 2.0 & 0.8 \\
\cline { 2 - 4 } & $\mathrm{Al}_{2} \mathrm{O}_{3}$ & 17.3 & 2.7 \\
\cline { 2 - 4 } & $\mathrm{Fe}_{2} \mathrm{O}_{3}$ & 8.9 & 4.0 \\
\cline { 2 - 4 } & $\mathrm{Cr}_{2} \mathrm{O}_{3}$ & 18.7 & 20.0 \\
\cline { 2 - 4 } & $\mathrm{MgO}$ & 52.2 & 72.0 \\
\hline \multicolumn{2}{|c|}{ Bulk density } & 3.33 & 3.30 \\
\hline \multicolumn{2}{|c|}{ Apparent porosity $(\not 6)$} & 12.7 & 11.5 \\
\hline \multicolumn{2}{|c|}{ H.M.O.R (at.1480 $\left.\left.{ }^{\circ} \mathrm{C}\right) \mathrm{kg} / \mathrm{cm}^{2}\right)$} & 260 & 195 \\
\hline
\end{tabular}

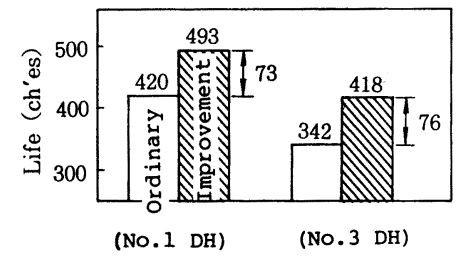

Fig. 3 Test result of $\mathrm{MgO} \cdot \mathrm{Cr}_{2} \mathrm{O}_{3}$ Sintered brick 
1. 緒言

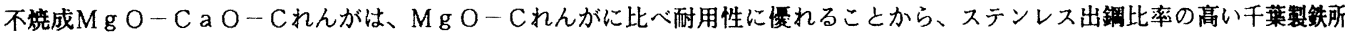
$85 \mathrm{t}$ 転炉 (K-BOP) において、内張り耐火物として使用されている。

$\mathrm{Mg} \mathrm{O}-\mathrm{C}$ a O - Cれんがの高温下における挙動を調查したところ、酸化物成分の炭素による遝元、並びに $\mathrm{Mg}$ 成分及び $\mathrm{C}$ a成 分のれんが内での移動が認められたので報告する。

2. 実㫫

Table 1 に、実矣に供したれんがの品澌を示す。C a O源にはC a Oを約 $30 \%$ 含有する綐結 $\mathrm{g}$ O O C a Oクリンカーを、 $\mathrm{Mg} O$ 源には海水 $\mathrm{Mg} O$ Oクリンカーを、炭素源には鳞状黒鉛を使用した。ただし、れんが Dは M g O-C a Oクリンカーと黒鉛の みの組み合わせである。供試れんがより切り出した円筒形の試片をFig. 1 の如く炭素管状発熱体内に設置し、 $1 \mathrm{~N} \ell / \mathrm{min} の$ A rガス流中て $1500^{\circ} \mathrm{C} \sim 1750^{\circ} \mathrm{C}$ の範囲内で 1 時間加熱し、重量減少率の測定及びれんが組織の観察を行った。

3. 実験結果及び考察

Fig. 2 にれんがA及びDの加熱による重量減少率を示す。れんがA 及びDの重量減少率は、加熱温度の上昇に伴って增大し、特に $1700^{\circ} \mathrm{C}$ 以 上で急增している。C a O含有量の多いれんがDは、C a Oを含まない れんがAに比へ、重量減少の傾向はほとんど同様であるが、その重量減 少率は $1700^{\circ} \mathrm{C}$ 以上において幾分小さい。

Photo. 1 に $1750^{\circ} \mathrm{C} て ゙$ 加熱したれんがBの加熱面近傍のE P MAによ る特性 X線像を示す。上段は加熱面より $2 \mathrm{~m}$ 内部の $\mathrm{Mg} O$ O粒子周辺、下 段は加熱面より 6 内部の $\mathrm{Mg} \mathrm{O}-\mathrm{C}$ a O精子である。 $\mathrm{Mg} \mathrm{O}-\mathrm{C}$ a O 粒子は外周部から $\mathrm{Mg}$ Oが消失していた。一方、加熱面側の $\mathrm{Mg} O$ 粒子 の表面には C a Oの存在が認められた。また、 $\mathrm{C}$ a O量の多いれんが $\mathrm{D} の 1750^{\circ} \mathrm{C}$ 加熱後試片では、X線回析結果から $\mathrm{C} \mathrm{a} \mathrm{C} 2$ が検出された。 これらの結果は、れんが中の酸化物成分が炭素によって摆元され"、 かつ、 $\mathrm{Mg}$ 成分及び $\mathrm{a}$ 成分はれんが内を移動したことを示し、さらに、 れんがを構成する各醉化物成分や炭素の間で相互に酸化逼元反応が起き ていることを示唆するものと考えられる。
Table 1 Properties of bricks

\begin{tabular}{ccccc}
\hline & A & B & C & D \\
\hline $\begin{array}{c}\text { Chomical Composition }(X) \\
\text { MoO }\end{array}$ & 60 & 50 & 40 & 20 \\
CoO & & 10 & 20 & 40 \\
C & 40 & 40 & 40 & 40 \\
Cold Crushing Strength & & & \\
(kgt/cm") & 220 & 212 & 209 & 201 \\
\hline
\end{tabular}

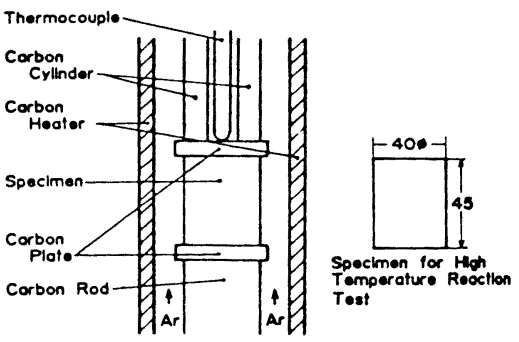

Fig. 1 Apparatus for high temperature reaction test

<文献> 1) 海老沢ら ; 䇺業協会昭和62年年会講演予稿集, Vol.3 3C03 755-756 (1987)

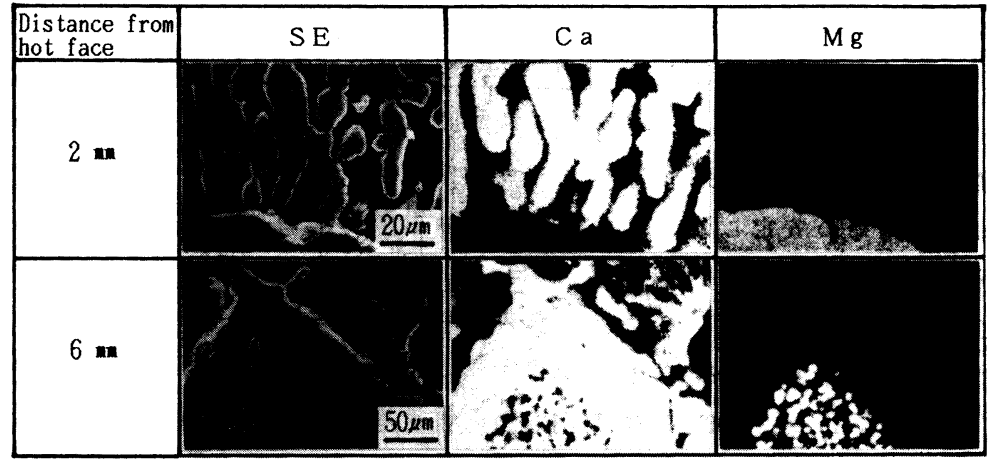

Photo. 1 Characteristic X-ray Images of brick B after heated at $1750^{\circ} \mathrm{C}$

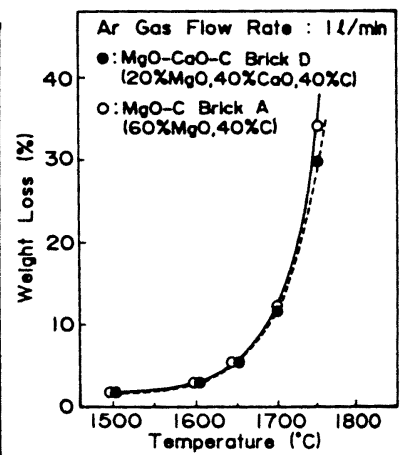

Fig. 2 Relation between weight loss and heating temperature 


\section{1. 緒 言}

タンディッシュ（以下T D と略す）内での溶鋼中介在物浮 Table 1 Properties of weir refractories 上分離を図る目的で T D 内に堰を設けている。堰材質として は通常アルミナシリカ系プレキャストブロックが使用されて いる。今回堰材質の再検討を行った結果、堰寿命が向上し炬 材コスト削隇が可能となったのでその概要にっいて報告する

\section{2. 暒用耐火物改善の考え方}

$\mathrm{T} \mathrm{D}$ 用堰炉材コスト削減の考え方として溶鋼、T D スラグ に対し高耐食性であり、耐スポーリング性に優れているあの が望まれる。そこでてれらの具備特性をもとにアルミナ含有 量、材料の結合形態、スチールファイバー添加の有無等を見 直し、4種の供試材料について評価試験を行い材料の選択を 実施した。従来及び改善品の基礎物性の一例を表 1 に示す。

\section{3. 評価試験}

\section{1）耐食性試験}

回転スラグ侵食炬により、スラグ回転侵食試験を行った。 試験条件として、試験時間 1220 分、温度 $16000{ }^{\circ} \mathrm{C}$ 、ス グ $\mathrm{C} / \mathrm{S} \doteqdot 1$ のあので行った。その結果を図 1 亿示す。てれよ り改善品は從来品に比べ約 13 倍の耐食性向上が確認できた。

\begin{tabular}{|c|c|c|c|}
\hline & Conventiona & Improved \\
\hline \multirow{2}{*}{$\underset{\text { Composition }}{\text { Cheal }}$} & $\mathrm{SiO}_{2}$ & 38 & 32 \\
\hline & $\mathrm{Al}_{2} \mathrm{O}_{3}$ & 56 & 67 \\
\hline \multicolumn{2}{|l|}{ Bulk density } & 2.35 & 2.79 \\
\hline \multicolumn{2}{|c|}{ Crushing strength $\left(\mathrm{kg} / \mathrm{cm}^{2}\right)$} & 980 & 1120 \\
\hline \multicolumn{2}{|c|}{$\begin{array}{l}\text { Thermal linear change expansion (क) } \\
\left.\text { (at } 1500^{\circ} \mathrm{C} \text { ( } 3 \mathrm{Hr}\right)\end{array}$} & -0.08 & +0.97 \\
\hline \multicolumn{2}{|c|}{ Fiber content (wt $\%$ ) } & 3 & 0 \\
\hline
\end{tabular}

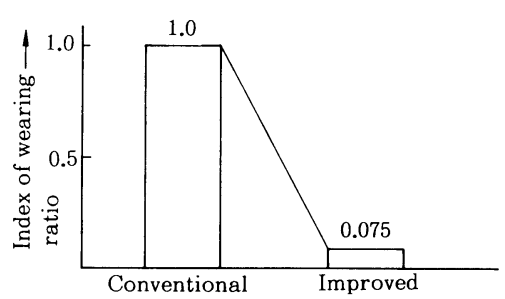

Fig. 1 Result of corrosion test

Table 2 Result of spalling test

\begin{tabular}{|c|c|c|}
\hline & $\mathrm{n}$ & $\begin{array}{l}\text { The number of heat } \\
\text { cycle specimen } \\
\text { fracture }\end{array}$ \\
\hline Conventional & 3 & 8 \\
\hline Improved & 3 & $>20$ \\
\hline
\end{tabular}

2 ) 耐スポーリング試験

耐スポーリング試験として電気炬によるサイコロスポーリ ング試験を実施した。試験方法としては4 0 mn 角のサイコロ 状に成型した試料を電気炬にて $15500{ }^{\circ} \mathrm{C}$ まで急熱し 20 分 保定後水冷のくり返しで試料の破壊する回数を調查した。乙 れょり改善品は従来品に比べ耐スポーリング性に優れている ことが確認できた。

以上の評価試験の結果より改善品の有意性が確認できたの で実機での評価試験を行った。

\section{4. 実機評価試験}

実機試験は当所三製鋼工場 1 C C にて行い従来品との寿命 の比較を行った。その結果を表 2 亿示す。とれより改善品は 従来品に比べ 4.5 倍の寿命に向上出来た。

\section{5. 結 言}

今回の高耐食性堰を適用するととにより約 4.5 倍の寿命向 上が可能となり、図 3 亿示すように堰原単価指数で約 $56 \%$

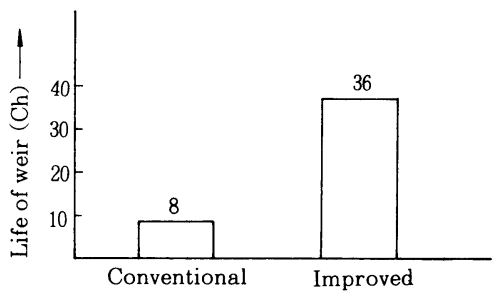

Fig. 2 Comparison between conventional and improved weir life

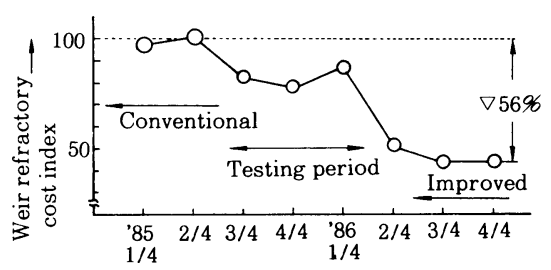

Fig. 3 Transition of weir refractory cost index の削减が達成できた。 
（258） タンディッシュ内溶鍋加熱用耐火物とその施工法の開発

\section{1. 緒言}

千葉製鉄所では、タンディッシュ内溶銅加熱設備（以下 $\mathrm{T} / \mathrm{D}$ ヒーターと称す) を昭和 60 年 11 月から工程化し、ステンレス

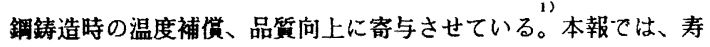

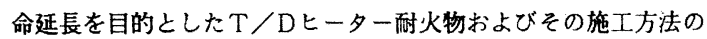
開発について述へる。

\section{2.インダクターの耐火物組成}

インダクターは通常の保持炬と比へてて加熱冷却サイクルが短い のて、インダクターの溶鋼加熱湿（チャンネル）を構成する耐火 物には対策を講じなければならない。一方チャンネル内は、溶龬 流動が激しいためチャンネル壁は繳密な焼結居て構成する必要が ある。従来は冷却時に発生するチャンネル壁の裂を最小限に抑 え、かつ発生した裂が加熱時にはふさがることを狙い残存膨張 性を有し焼結層の移動を拘束しないように $\mathrm{MgO}-\mathrm{Al}_{2} \mathrm{2}_{2} \mathrm{O}_{3}$ 系の ラミング材（ラミング材A）を採用していた。このラミング材 $\mathrm{A}$ はスピネル生成量が多くすなわち烧結居が厚くなりすぎるため加 熱時の裂閉塞が不十分で溶鋼差込みトラブルがしばしば発生し た。そこて Table.1に示す $\mathrm{Mg} \mathrm{O}-\mathrm{A} \ell_{2} \mathrm{O}_{3}$ スピネル系材料Bを 適用しラミング材の過赎結性を抑制した。Fig.1 には枌状耐火物 の残存競張率をスピネル生成反応の指標として繰り返し加熱条件

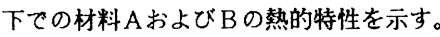

\section{3. オフラインチャンネル成形技術}

インダクター施工時、チャンネル部には中子（テンプレート） を装入する。従来、チャンネル壁は、T/Dヒーター初回操業時 にジュール熱と溶鋼熱によりラミング材を娧結させて形成してい た。しかしながらこの方式では、加熱時の溶鋼流動に応じた烧結 強度か得られない場合が発生し、インダクター低寿命の主要因となっていた。それゅえラミング材施工後、あらかじめオフライン て所定厚みの楼結層を形成させてからタンディッシュに取り付けるチャンネル成形技術を開発した。

\section{4. 改善の効果}

インダクター耐火物寿命をFig.2 に示す。上記改善後は、低寿命のヒーターかなくなり、平均寿命は従来の 4 倍に延びた。
川崎製鉄（株）千葉製鉄所 ○大杉 仁 山中啓充 海老沢律 技術研究本部針田柣

Table. 1 Composition of inductor retractory.

\begin{tabular}{|c|c|c|c|}
\hline & $\mathrm{MgO}(\%)$ & $\mathrm{Al} 2 \mathrm{O} 3(\%)$ \\
\hline \multirow{2}{*}{ Ramming material } & $\mathrm{A}$ & 69 & 30 \\
\cline { 2 - 4 } & $\mathrm{B}$ & 52 & 46 \\
\hline
\end{tabular}

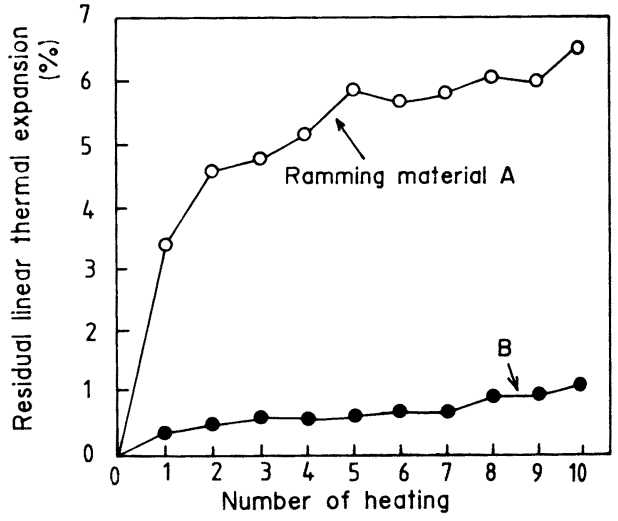

Fig. 1 Relation of number of heating and residual linear thermal expansion.

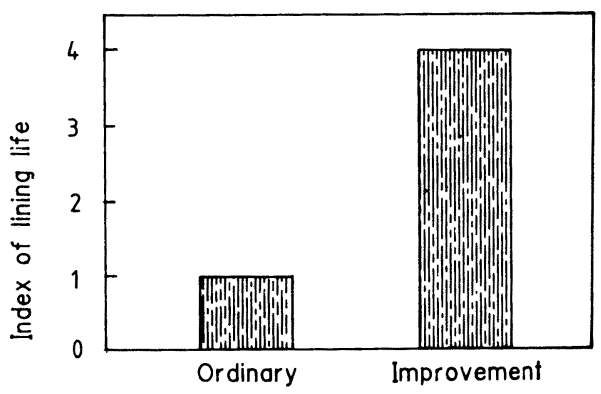

Fig. 2 Improvement of lining life of inductor.

（参考文献）1）大杉ら：第114回講演大会討論会発表予定 


\section{$(259)$ 連鋳用スライディングプレートの改善

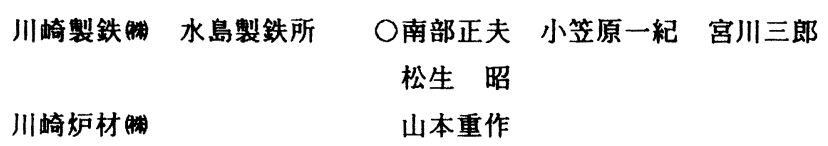

' $87-\mathrm{S} 995$

1. 緒言

連鋳用スライディングブレートのコストを削減するため, タンディッシュ連々数を增加させることおよびブレート 形状の小型化を実施してきた。しかしながら，オーダー構成上連々数を增加させることには限界がある。それ仲え， プレートコストをさらに削減する手段として，使用後のプレートを回収後再セットして使用する方法がある。しかし この方法は，回収したプレートの割れのため実行が困難であった。今回，プレートの割れのメカニズムを検討し，材 質の改善および使用方法の改善を行い，プレートの再使用技術を確立したので，その結果について報告する。

2. 実警方法 プレートの熱応力解析を実施した。その結 果,プレートは鋳込み初期の熱応力により割れ，鋳込み終 了後の彾却時にその割れが伸展すると推察される。熱スポ 一ルによる割れの発生特性を示すパラメーターとして一般 に用いられている熱破壊抵抗係数 $\mathrm{R}^{\prime}$ および発生した割れ の伸展の程度を表わすパラメーターとして一般に用いられ

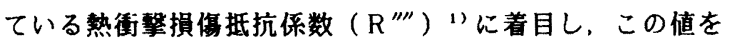
変えた各種プレートを試作し，実機テストを実施した。

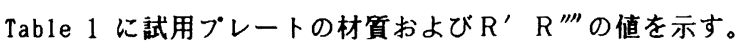
3. 実鵌結果と考察 Fig.1 $\mathrm{KAl}_{2} \mathrm{O}_{3}-\mathrm{SiO}_{2}-(\mathrm{C}+\mathrm{SiC})$ 系プレ 一トにおける成分とプレート再使用比率の関係を示す。ま たFig.2にR北とプレート再使用比率の関係を示す。C含

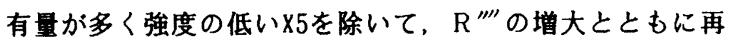
使用率は增加する。 $\mathrm{R}^{\prime}$ とプレートの再使用率には相関が 認められない。Fig.3 にプレート取外し時のプレート温度 と発生した割れの長さとの関係を示す。ブレート温度の低 下とともに発生した割れの長さが減少する。それゆえ、プ レートの再使用率をあげるため，割れの伸展を防止するこ

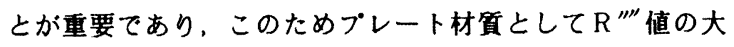
きい材資を選定すること，およびブレートの徐冷をするこ とが必要である。

4. 結言 プレートの再使用比率をあげるため $\mathrm{R}^{\prime} \mathrm{R}^{\prime \prime r}$ 值 に着目し、この値を変えた材筫を試作し、実機テストした。 この結果, 以下のことがわかった。

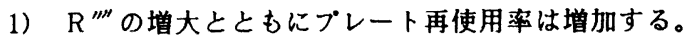

2） $R^{\prime}$ と再使用率とは相関が認められない。

3）プレート取外し時の温度の低下とともに，発生した 割れの長さが娍少する。

4）プレートの再使用率をあげるには，発生した割れの 伸展を抑制することが必要である。

<参考文献> 1) 中山ら;材料第32巻, 第357号 (1983)
Table 1 Typical properties of sliding plate

\begin{tabular}{|c|r|r|r|r|r|r|r|}
\hline \multicolumn{2}{|l|}{} & $\times 1$ & $\times 2$ & $\times 3$ & $\times 4$ & $\times 5$ & $\times 6$ \\
\hline Chenical & $\mathrm{Al}_{2} \mathrm{O}_{3}$ & 78.5 & 75.7 & 84.0 & 82.3 & 71.4 & 93.0 \\
Composition & $\mathrm{SiO}_{2}$ & 6.4 & 9.2 & 2.0 & 6.1 & 8.0 & 2.0 \\
$(\%)$ & $\mathrm{C}$ & 9.8 & 9.8 & 9.5 & 6.3 & 15.5 & 4.0 \\
& $\mathrm{SiC}$ & 3.8 & 3.5 & 3.4 & 3.8 & 3.6 & - \\
\hline $\mathrm{R}^{\prime}$ & 26 & 24 & 29 & 24 & 28 & 31 \\
\hline $\mathrm{R}^{m m}$ & 215 & 203 & 213 & 171 & 244 & 138 \\
\hline
\end{tabular}

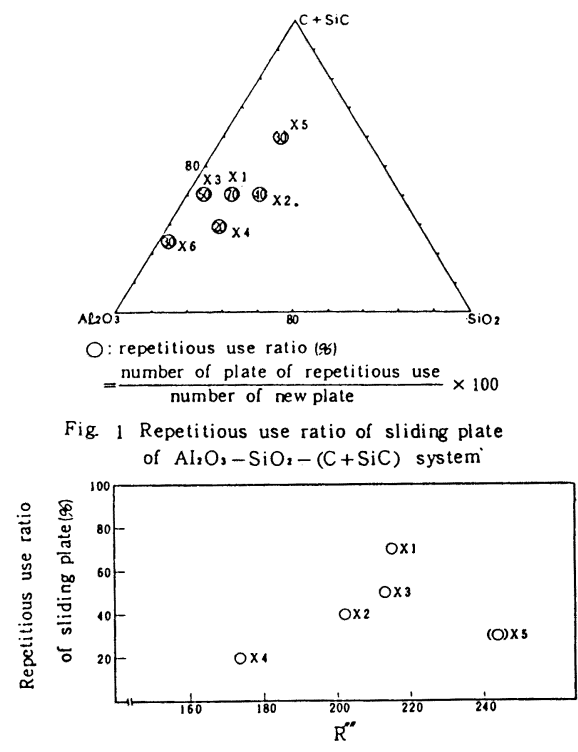

Fig. 2 Relation between $R^{\sim}$ and repetitious use ratio

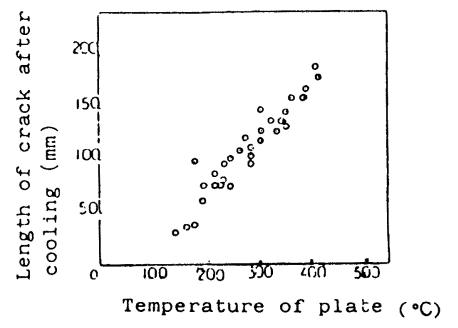

Fig. 3 Relation between length of crack and Temperature of plate 


\section{1. 緒 言}

連䤻用漫漬ノズルの損耗は、パウダーライン部の $\mathrm{Z} \mathrm{r} \mathrm{O}_{2}-\mathrm{C}$ 材質の溶損と、内孔部吐出口先端で生じる $\mathrm{Al}_{2} \mathrm{O}_{3}$ - C 材質の損傷に分類され、いずれも浸漬ノズルの安定使用に大きな意味をるつ。今回、当所第 3 連鉡設備にお レて低炭アルミキルド鋼で使用した浸漬ノズルの調査から、その損耗機構を検討した。

\section{2. 実機使用結果}

Table 1 亿実機に使用した浸漬ノズルの品質を示す。 ノズル Bはノズル $\mathrm{A}$ と比較して、 $\mathrm{Z} \mathrm{r} \mathrm{O}_{2}-\mathrm{C}$ 部で未安定化 $\mathrm{Zr} \mathrm{O}_{2}\left(\mathrm{~m}-\mathrm{Zr} \mathrm{O}_{2}\right)$ の配合比率を高め、をた、 $\mathrm{Al}_{2} \mathrm{O}_{3}-\mathrm{C}$ 部で $\mathrm{SiC}+\mathrm{SiO}_{2}$ 量を减少させた。

Fig. 1 イパウダーライン部での損耗結果を示す。Bは鉡 込時間の増加にるかかわらず安定した損耗を示した。

Fig. 2亿吐出口部での損耗結果を示す。浸漬梁さが浅い ほど、損耗は增大する傾向が認められた。この部位です、 Bの耐用が良好であった。

\section{3. 考察}

パウダーライン部 $\left(\mathrm{Zr} \mathrm{O}_{2}-\mathrm{C}\right.$ 材質) では、パウダー中の $\mathrm{Si} \mathrm{O}_{2}, \mathrm{Na}_{2} \mathrm{O}$ 等の成分が液相として $\mathrm{Zr} \mathrm{O}_{2}$ 粒子内へ浸閏 し、安定化剤の $\mathrm{CaO}$ 成分を離溶するととから、 $\mathrm{ZrO}_{2}$ 粒子 は粒外周部より細粒化し、溶出してゅくことが知られてい る。 ${ }^{12)}$ とのととから、 $\mathrm{m}-\mathrm{Zr} \mathrm{O}$ 粒子の配合比率の高い $\mathrm{B} の$ 耐用が良好であったと考えられる。

吐出口部 $\left(\mathrm{Al}_{2} \mathrm{O}_{3}-\mathrm{C}\right.$ 材質)では、水モデル実験から、浸 漬梁さの浅い場合に当該部位が堿圧状態となる事実、およ び、使用後の検鏡結果では、 $\mathrm{SiO}_{2}$ の消失が認められること から、 $\mathrm{SiO}_{2}$ 成分の減圧下での還元消失が進行し、溶鋼流の アタックを受け、摩耗損傷すると考えられる。したがって $\mathrm{SiC}+\mathrm{SiO}_{2}$ 量の少ない $\mathrm{B}$ の損耗が軽微であったと推定さ れる。

\section{4. 結 曹}

漫漬ノズルのパウダーライン部では、 $\mathrm{m}-\mathrm{ZrO}_{2}$ 粒子の配 合量を增すととにより、また吐出口部では、 $\mathrm{SiC}+\mathrm{SiO}_{2}$ 量を減らすととにより、損耗は軽减される。

<参考文献 $>$

1) 池田ら；耐火物 39 (3) 130 135(1987)

2) H.Kyoden et al. ; 1 st. Intnl. Confer. Ref., Tokyo ( 1983 )

3) Y. Imai ida et al.; 29 th. Intnl. Col loq. Ref., Aachen (1986)
Table 1 Properties of submerged nozzles

\begin{tabular}{|c|c|c|c|c|}
\hline \multirow{2}{*}{ Nozzles } & \multicolumn{2}{|c|}{$\mathrm{ZrO}_{2}-\mathrm{C}$} & \multicolumn{2}{|c|}{$\mathrm{Al}_{2} \mathrm{O}_{3}-\mathrm{C}$} \\
\hline & A & B & A & B \\
\hline $\begin{array}{c}\text { Chemical composition } \\
(\%) \\
\mathrm{Al}_{2} \mathrm{O}_{3} \\
\mathrm{SiC}+\mathrm{SiO}_{2} \\
\mathrm{ZrO}_{2} \\
\mathrm{CaO} \\
\mathrm{F} . \mathrm{C} .\end{array}$ & $\begin{array}{r}0.4 \\
5.1 \\
69.6 \\
5.2 \\
17.3\end{array}$ & $\begin{array}{r}0.3 \\
14.9 \\
69.1 \\
1.8 \\
14.5\end{array}$ & $\begin{array}{r}50.0 \\
24.2 \\
- \\
0.3 \\
23.0\end{array}$ & $\begin{array}{r}69.7 \\
5.9 \\
- \\
0.3 \\
25.0\end{array}$ \\
\hline$m-\mathrm{ZrO}_{2} \underset{(q)}{\mathrm{ratio} \text { in } \mathrm{ZrO}}$ & 12.7 & 88.9 & - & - \\
\hline Apparent porosity & 14.4 & 17.3 & 14.9 & 14.9 \\
\hline Bulk density & 3.49 & 3.42 & 2.39 & 2.65 \\
\hline Modulus of rupt ure & 119 & 102 & 135 & 142 \\
\hline
\end{tabular}

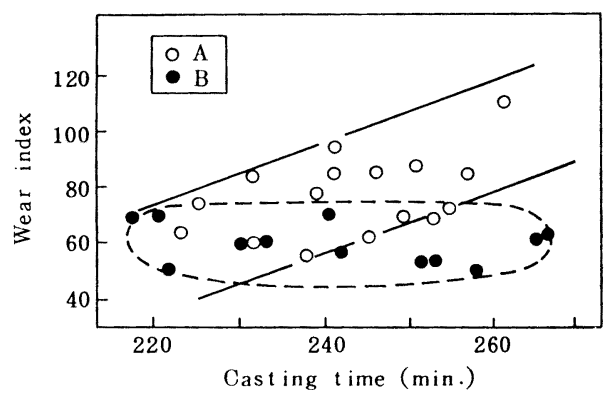

Fig. 1 Relation between casting time and wear of powder line at submerged nozzle.

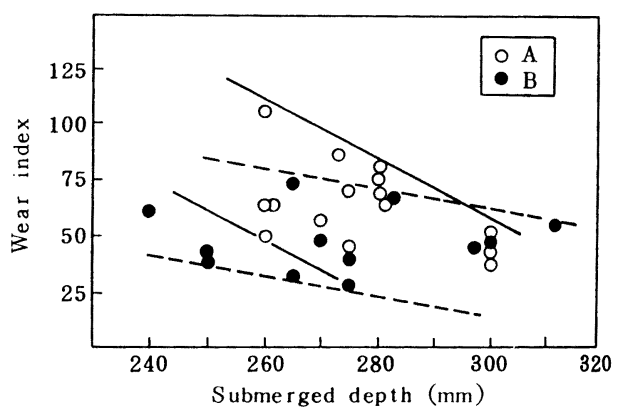

Fig. 2 Relation between submerged depth and wear of outlet of submerged nozzle. 


\title{
（26I）アアルミナ付着防止用浸漬ノズルの開発
}

\author{
日本鋼管福山製鉄所水岡誠史内野 薰○森 孝志 \\ 福山研究所(工博)北川 融手嶋俊雄
}

\section{1. 緒 言}

連続鋳造において浸漬ノズルは、鋼の品質を決定する上で極めて重要な要素の1つである。実操業に おいては、 $\mathrm{Ar}$ ガスをノズル内に吹込み $\mathrm{Al}_{2} \mathrm{O}_{3}$ 付着防止を図っているが、その多少によっては鋳片欠陥あ るいは、操業トラブルが発生する場合がある。そこで、今回浸漬ノズル材質、及び形状の面から改善を 行ない $\mathrm{Al}_{2} \mathrm{O}_{3}$ 付着防止に関して $2 \sim 3$ の知見が得られたので以下に報告する。

\section{2. テスト方法}

Table 1 に本試験に供した浸漬ノズルの化学成分值等を示す。 鋳造対象鋼種は低炭アルミキルド鋼とし、鋳造マシンは福山 2 , $5 \mathrm{c} \mathrm{CM} ゙$ ある。又 $\mathrm{Al}_{2} \mathrm{O}_{3}$ 付着量は、最大付着量となる吐出孔直 上の 4 点で評価した。

3. 結 果

3 - 1. 浸漬ノズル材質の影響

Fig. 1 に鋳造時間とノズル部位別の $\mathrm{Al}_{2} \mathrm{O}_{3}$ 付着量の関係を示 す。 $\mathrm{Al}_{2} \mathrm{O}_{3}$ 付着量は、浸漬ノズルのモールド幅方向と厚み方向、 いずれの部位においても材質変更品である $\mathrm{B}, \mathrm{C}_{1}, \mathrm{C}_{2}, \mathrm{C}_{3}$ ノズ ルの中では $\mathrm{C}_{1}$ のみ改善効果が認められた。これは、ノズル壁面 の平滑度が最も優れていること及び、組成中の $\mathrm{SiC}, \mathrm{SiO}_{2}$ の低 減を図ることによって、酸素供給源あるいは表面平滑度悪化の 原因となる $\mathrm{SiO}(g)$ の発生を抑制したためと考えられる。又幅方 向に比較し、厚み方向の $\mathrm{Al}_{2} \mathrm{O}_{3}$ 付着量が早期に急増する理由と しては、一孔から二孔に分岐する部位において急激な流速低下、 即ち“よどみ”が発生し、溶鋼中の脱酸生成物が急激に付着す るものと考えられる。

\section{$3-2$. 浸漬ノズル形状の影響}

浸漬ノズル内のモールド厚み方向の“よどみ”を解消する為、 厚み方向のノズル内径を絞った形状变更品の使用テストを行っむ た。Fig. 2 に使用結果を示す。厚み方向の $\mathrm{Al}_{2} \mathrm{O}_{3}$ 付着量は従来 形状ノズルに比較し $1 / 3$ 以下と大巾に低減した。

\section{4. 結 言}

福山 2, 5 C C M においては、ノズル材質, 形状の両面から $\mathrm{Al}_{2} \mathrm{O}_{3}$ 付着防止を可能とするノズを製作し適用拡大を図っ ている。
Table.l. Chemical composition of submerged nozzle.

\begin{tabular}{|c|c|c|c|c|c|}
\hline & $A$ & $B$ & $I$ & 2 & 3 \\
\hline $\mathrm{C}$ & 27.8 & 23.0 & 13.5 & 14.1 & 14.1 \\
\hline $\mathrm{ZrO}_{2}$ & - & - & 72.3 & 70.5 & 66.3 \\
\hline $\mathrm{Al}_{2} \mathrm{O}_{3}$ & 45.9 & 71.7 & - & - & - \\
\hline $\mathrm{SiC}$ & - & 4.5 & 9.7 & 9.4 & 9.4 \\
\hline $\mathrm{SlO}_{2}$ & 25.6 & - & - & - & - \\
\hline $\mathrm{CoO}$ & - & - & 3.0 & 5.3 & 9.9 \\
\hline $\begin{array}{r}\text { roughness } \\
(\mathrm{mm})\end{array}$ & 22.6 & 22.5 & 15.3 & 21.3 & 19.9 \\
\hline
\end{tabular}

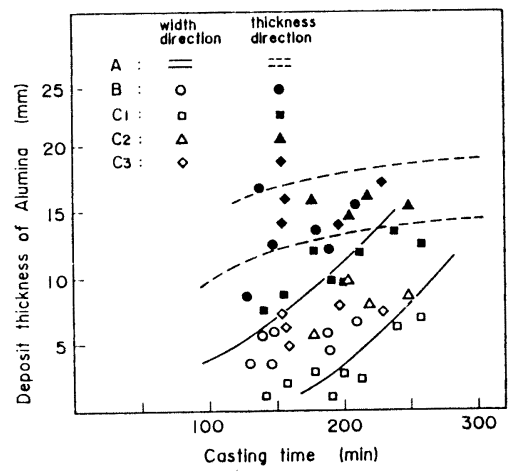

Fig.-I Relotionship between costing time and deposit thickness of Alumina.

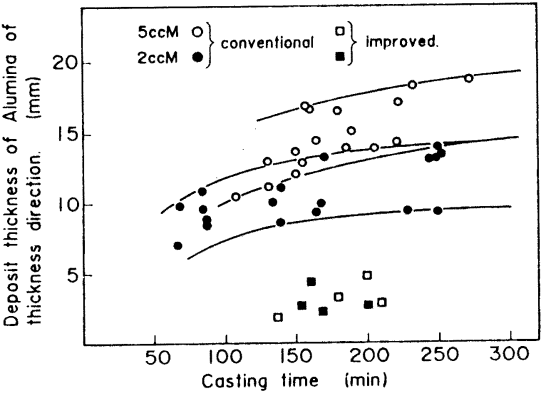

Fig-2 Result of improved submerged nozzle. 
' $87-\mathrm{S} 998$

（262）アルミナ付着におよほす連鋳浸漬ノズル材質の影響

( 連鋳浸漬ノズル閉塞機構とその防止技術第一報)

住友金属工業哧) 総合技術研究所 川崎守夫 中島敬治 $\bigcirc$ 笠井宣文 鹿島製鉄所佐藤 敦

1. 緒言

連鋳浸漬ノズルの閉塞は高速鋳造を指向する上で安定操業の阻害, 偏流による鋳片表面品質の悪化等 の問題があり多くの研究 ${ }^{124)}$ がなされている。しかしながら抜本的な解決には至っておらず早急に解决 すべを問題である。そこで著者らはジルコニアグラフアイト（以下 $Z \mathrm{G}$ と略す）を基本とした材質に， $\mathrm{CaO}, \mathrm{MgO}$ を添加した時の $\mathrm{A}_{2} \mathrm{O}_{3}$ の付着状況について高周波誘導炉を用いた基礎試験を行い, $\mathrm{A}_{2} \mathrm{O}_{3}$ 付着 に対して興味ある知見が得られたので報告する。

\section{2 . 実験方法}

冷延向低炭アルミキルド鋼を $\mathrm{A}_{2} \mathrm{O}_{3}$ ルツボ中で $130 \mathrm{~kg}$ 溶解し $1550{ }^{\circ} \mathrm{C}$ に保持 した後に Z Gサンブルを 30 分間浸漬した。浸漬中の二次酸化を防止するため に炉蓋を設置するとともにArシールを行った。（Fig１１）

浸漬した Z Gサンブルの組成はTable 1 のとおりである。

3 . 実験結果と考察

浸漬後サンブルを切断し稼動面をS EMで観察した結果, $Z$ G 材質のみでは 界面において化学的変化は全く認められないにも係わらず $\mathrm{A}_{2} \mathrm{O}_{3}$ の付着量は多 く物理的な結合によって $\mathrm{A}_{2} \mathrm{O}_{3}$ は堆積している。一方, $\mathrm{ZG}-\mathrm{CaO}-\mathrm{SiO}_{2}$ 系 の材質においては, $\mathrm{A}_{2} \mathrm{O}_{3}$ の付着がある場合とない場合が認められたため, 界面

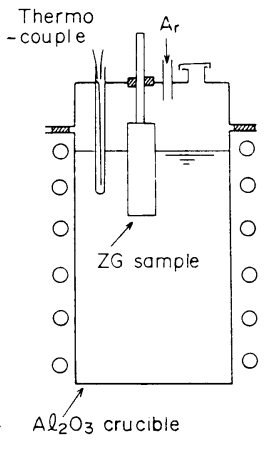

Fig. I Experimental apparatus の付着物を採取し化学分析を行った結果, 両者とも $\mathrm{A}_{2} \mathrm{O}_{3}-\mathrm{SiO}_{2}-$ $\mathrm{CaO}$ 系の化合物であるが $\mathrm{A}_{2} \mathrm{O}_{3}$ の付着が認められた材質において は，高虽点化合物が生成しておりそれを核として $\mathrm{A}_{2} \mathrm{O}_{3}$ が付着し ている。また $\mathrm{A}_{2} \mathrm{O}_{3}$ 付着が認められなかった材質は低融点化合物 が生成しており， $\mathrm{A}_{2} \mathrm{O}_{3}$ の成長が阻害されているすのと推定され

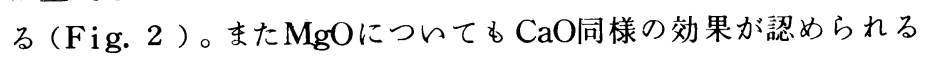
ことがわかった。

以上の結果より, $\mathrm{Z} \mathrm{G}-\mathrm{CaO}$ (または $\mathrm{MgO}$ ) - $\mathrm{SiO}_{2}$ 系の材質に おレては三者の比率を適正化することにより, 低融点化合物を生 成させることが $\mathrm{A}_{2} \mathrm{O}_{3}$ 付着に対しては有効であることが判明した。 4. 結 言

$Z \mathrm{G}$ 材質において, $\mathrm{A}_{2} \mathrm{O}_{3}$ 付着を低減させることを目的に高周 波誘導炉を用いた基礎試験を行い, $Z \mathrm{G}$ 材質のみでは物理的結 合による $\mathrm{A}_{2} \mathrm{O}_{3}$ 付着が認められ $\mathrm{CaO}(\mathrm{MgO}), \mathrm{SiO}_{2}$ の適量添加 により $\mathrm{A}_{2} \mathrm{O}_{3}$ 付着を抑制させ得ることがわかった。 参考文献

Table I Chemical composition of ZG samples

\begin{tabular}{|c|c|c|c|c|c|c|}
\hline $\begin{array}{c}\text { Sample } \\
\mathrm{No}\end{array}$ & $\mathrm{ZrO}_{2}$ & $\mathrm{C}$ & $\mathrm{SiO}_{2}$ & $\mathrm{Al}_{2} \mathrm{O}_{3}$ & $\mathrm{CaO}$ & $\mathrm{MgO}$ \\
\hline $1 \sim 12$ & $\begin{array}{l}61.0 \sim \\
76.0\end{array}$ & 24.0 & $0 \sim$ & $0 \sim$ & $0 \sim$ & $0 \sim$ \\
\hline
\end{tabular}

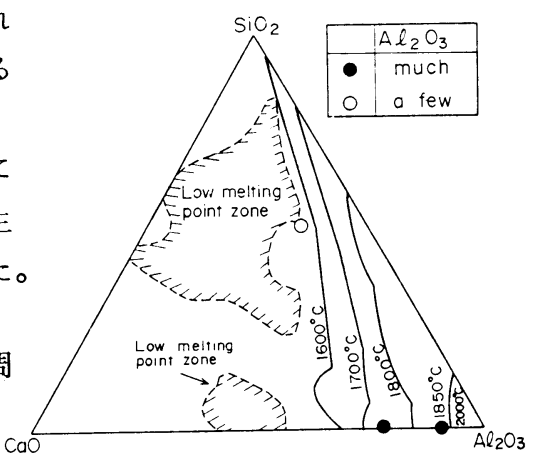

Fig.2 Precipitates composition produced at the interface between molten steel and $Z G$
1) Hauck ら: Arch Eisenhüttenwes., 53(1982), Nr. 4, April, P127。
2) 金子ら：鉄と鋼，66(1980), S 868 .
3) 福田ら：鉄と鋼, $72(1986)$, S 280 .
4) 平櫛ら：耐火物, 35-539 (1983), No. 9 . 
（263） VOD用取鍋耐火物への $\mathrm{MgO}-\mathrm{Cr}_{2} \mathrm{O}_{3}-\mathrm{ZrO}_{2}$ れんがの適用

' $87-$ S 999

日本鋼管(侏) 京浜製鉄所 山上 詃 宮野治夫 $○$ 須藤新太郎 長岡 博 旭硝子株) 七ラミックス事業部 小松英雄 林雄一郎 行縄次夫 鈴木浩一

1. 緒 言

当所のステンレス鋼は, VOD精錬で製造されている。最近の高級化指向に伴い, ステンレス鋼の低 $\mathrm{S}$, 低 $\mathrm{N}$, 低 $\mathrm{C}$ 化等, 苛酷索精錬が要求されている。乙のため, 従来のマグクロ系耐火物では炉寿命の 低下をるたらし,コストアップとなっていた。今回, これら重処理精鍊用耐火物として $\mathrm{MgO}-\mathrm{Cr}_{2} \mathrm{O}_{3}-$ $\mathrm{ZrO}$ （以下，MC Zれんがと称す。）れんがを開発し，実鍋試験を行ったのでその結果を以下に報告 する。

\section{MCZれんが開発の考え方}

重処理操業下の化学的侵食は, 高 $\mathrm{MgO}$, 高純度な組成の耐火物 が良好である。（図 1) しかし, スラグ侵潤により生じる構造 的スポール並びに熱間強度不足による摩耗損傷等の欠点がある。

$\mathrm{MgO}$ れがをべースに $\mathrm{ZrO}_{2} ， \mathrm{Cr}_{2} \mathrm{O}_{3}$ を添加して改善を試みた。 特に Z O O 上げ,さらに 2 面角を大をくして濡れ性を濡れにくくする(1) 等の 効果により，スラグ侵透防止に有効である。

3. 添加 $\mathrm{ZrO}_{2}$ の存在

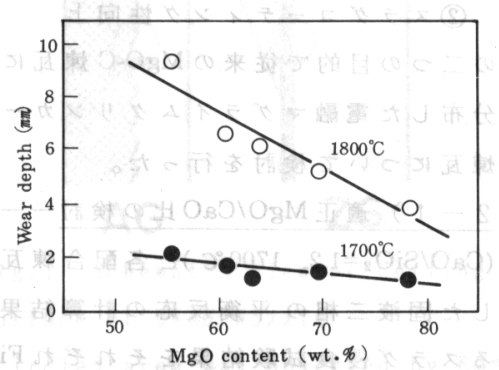

Fig. 1 Rclation betveen wear and $\mathrm{MgO}$ content in the $\mathrm{Mg}-\mathrm{Cr}$ brick

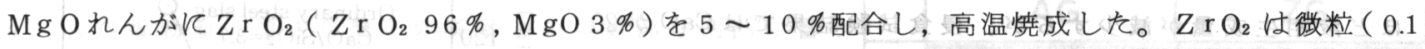
〜 $1.0 \mathrm{~mm}$ ) で配合するとMg O 骨材の隙間を埋めるよ とに存在し,ポンド部を形成する。（写真 1 ） $\mathrm{Z} \mathrm{r} \mathrm{O} 2$ を $0.2 \mathrm{~mm}$ 以上の中粒で用いると, その周囲の隙間及び微小クラックが発生して組織の脆弱化が見ら れる。乙れは, 耐食性の点からマイナスである。

\section{4. 、実炉試験結果}

$\mathrm{ZrO}_{2}$ 微粒を配合した M Z れん がとマグクロ質れんがをスラクライ ンにて張り分け試験した。品質表を 表 1 亿示す。重処理操業下では, ダ イレクトボンド品に比べ 1.6 倍, セ ミリボンド品に比べ 1.3 倍の高耐用 を示した。構造的スポーリングは, ほとんど生じていないが S EM 観察 すると, 稼動面付近では $\mathrm{Z} \mathrm{O} \mathrm{O}_{2}$ を中 心としたボンド部分がスラグによっ
Table 1. Typical properties of test bricks

\begin{tabular}{|c|c|c|c|}
\hline & $\begin{array}{l}{\mathrm{MgO}-\mathrm{Cr}_{2} \mathrm{O}_{3}-}^{\mathrm{ZrO}_{2} \text { brick }}\end{array}$ & $\begin{array}{l}\text { Semi rebond } \\
\mathrm{Mg}-\mathrm{Cr} \text { brick }\end{array}$ & $\begin{array}{l}\text { Di rect bond } \\
\mathrm{Mg}-\mathrm{Cr} \text { brick }\end{array}$ \\
\hline Compositi on (\%) & 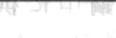 & 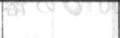 & \\
\hline $\mathrm{MgO}$ & 84.3 & 65.2 & 71.5 \\
\hline $\mathrm{Cr}_{2} \mathrm{O}_{3}$ & 7.5 & 23.0 & 16. 2 \\
\hline $\mathrm{ZrO}_{2}$ & 4. 8 & - & - \\
\hline $\mathrm{Al}_{2} \mathrm{O}_{3}+\mathrm{Fe}_{2} \mathrm{O}_{3}$ & 1.6 & 9.5 & 10.5 \\
\hline $\begin{array}{l}\text { Apparant } \\
\text { porosity }(6)\end{array}$ & 12.0 & 14.0 & 15.0 \\
\hline $\begin{array}{l}\text { Cold crushing } \\
\text { strength }\left(\mathrm{kg} / \mathrm{cml}^{\mathrm{l}}\right)\end{array}$ & 900 & 700 & 700 \\
\hline $\begin{array}{l}\text { Modulus of } \\
\text { rupturs }\left(\mathrm{kg} / \mathrm{cm}^{2}\right) \\
\text { at } 1500^{\circ} \mathrm{C}\end{array}$ & 50 & 70 & 60 \\
\hline
\end{tabular}

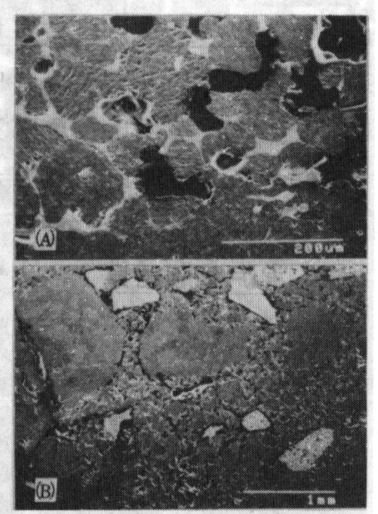

Poto. 1

Profile of $\mathrm{ZrO}_{2}$ in the brick af ter burning. (A) $-0.1 m m \mathrm{ZrO}_{2}$ added. (B) $1.2 \sim 0.15 \mathrm{~mm} \mathrm{ZrO}_{2}$ added. $\mathrm{CaO}, \mathrm{SiO}_{2}$ を吸収してスラグの侵閏を抑制していた。

5. 結 言重処理操業用スラグラインれんがとしてMCZれんがを開発し, ダイレクトボンド, セ ミリボンドれんがと張り分け試験を行った結果, 高耐用性が得られた。さらに耐食性の向上を図るへく， $\mathrm{ZrO}$ を中心としたボンド部分の強化を行ら所存である。

<参考文献〉 (1) A.M.Alper 5 : High Temperature Oxides part 1, 244(1970) 


\section{（264） クロム系ステンレス溶製炬に於る耐火物の改善}

\section{1. 緒 言}

当所第一製鋼工場 $175 \mathrm{t}$ 転炉（ＬＤ－－Ｂ）では、ステンレス溶製比率が高く内張り耐火物は低塩 基度スラグの存在下で高温にさらされる為、炉底、鋼浴部の溶損バランスがとれず耐火物コスト高騰の 要因となっていた。今回、 $\mathrm{MgO}-\mathrm{CaO}-\mathrm{C}$ 棟瓦をてれらの部位に適用し、良好な結果を得たので報告する。

\section{2. 煉瓦材質改善の考え方}

(1)高温下でのマグネシアーカーボン反応の緩和

(2)スラグコーティング性向上

の二つの目的で従来の $\mathrm{MgO}-\mathrm{C}$ 棟瓦に $\mathrm{MgO}$ 結晶粒界に $\mathrm{CaO}$ が 分布した電融マグライムクリンカーを配合した $\mathrm{MgO}-\mathrm{CaO}-\mathrm{C}$ 煉瓦について検討を行った。

$2-1$ ）適正 $\mathrm{MgO} / \mathrm{CaO}$ 比の検討- - - - 低塩基度 スラク $\left(\mathrm{CaO} / \mathrm{SiO}_{2}=1.2 、 1700^{\circ} \mathrm{C}\right)$ と各配合煉瓦成分についてモデル化 した固液二相の平衡反応の計算結果及び回転侵食炬におけ るスラグ侵食試験結果をそれぞれFig. 1，2 亿示す。ステ ンレス鋼スラグでは、モデル計算上棟瓦中の $\mathrm{CaO}$ \% が高い ほど液相生成量が減少するが、侵食試験結果では $\mathrm{CaO}$ が 20 \%程度から稼動面の変質層が増加するため見掛け上の溶損 指数が増加し、一般鋼スラグでは $15 \% よ り$ 溶損指数が増加 するととより $\mathrm{CaO}$ 含有量の適正値を $10 \sim 15 \%$ とした。 $2-2 ）$ 適正な黒鈶含有量の検討- - - - 黒鉛含有量に ついては、 $1650{ }^{\circ} \mathrm{C}$ の溶銑中に供試材を浸漬させ、その試験 前後の弾性率の比（ $\mathrm{E} / \mathrm{E}_{0} ）$ 及び $1700{ }^{\circ} \mathrm{C}$ の溶鋼中に供試材を $70 \mathrm{rpm}$ で 2 時間回転させた場合の摩耗量の測定から約 $15 \%$ を適正值とした。

\section{3. 実炉試験結果}

上記結果をもとに試作した $\mathrm{MgO}-\mathrm{CaO}-\mathrm{C}$ 棟瓦を炬底及び鋼 浴トラニオン壁に適用した結果、ステンレス溶製期間中の 炬底及び鋼浴トラニオン壁の溶損量が軽減され、Fig. 3 に 示す様に一炬代当りのステンレス溶製比率の向上と約 $20 \%$ の炉材コスト削減効果を得た。

\section{4. 結言}

ステンレス溶製炉用 $\mathrm{MgO}-\mathrm{CaO}-\mathrm{C}$ 棟瓦の開発を行い実炉に 適用した結果、ステンレス溶製比率の向上と大幅な炉材コ ストの削減が達成出来た。

<参考文献> 平櫛敬資：耐火物 39〔2〕 P. 91（1987）

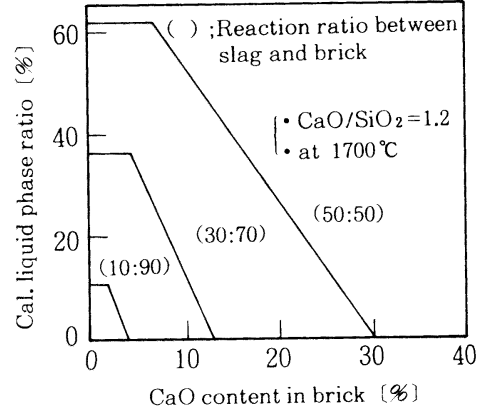

Fig. 1 Calculated liquid phase ratio from $1700^{\circ} \mathrm{C}$ isotherm section in the $\mathrm{CaO}-\mathrm{MgO}-\mathrm{SiO}_{2}$ system

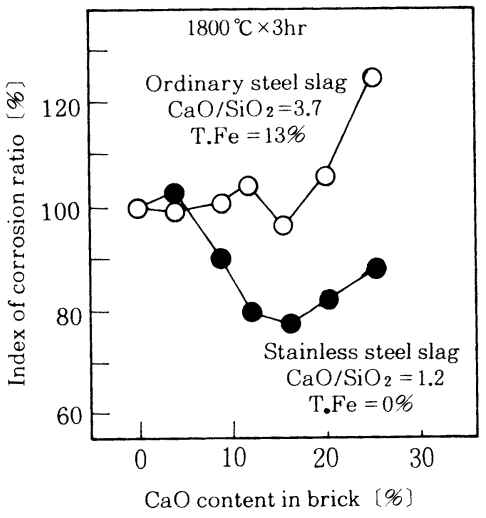

Fig. 2 Experimental results of slag corrosion test

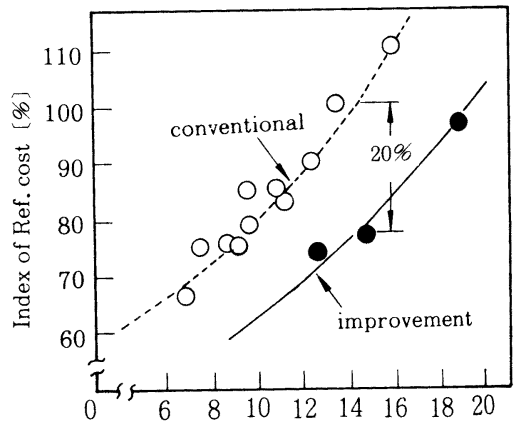

Heat ratio of stainless steel $[\%]$

Fig. 3 Relation between index of Ref.cost and heat ratio of stainless steel 


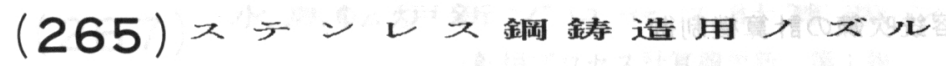

28 -S 1001

川崎妒材件 ○武下繁行長谷川晋新谷宏隆川上辰男

1.緒言：ステンレス鋼の連続鋳造に用いられるアルミナーグラファイト(A G) 質イマージョン) スルは内孔部の A G 質の变質, とくに黒鉛の消失による多孔筫化。C r を含む金属の析出といった特 異な現象を示す。飯田(1)らも同様の現象を認めており、そ の原因として、鋼中からのC r 酸化物等によるノズル中の C の酸化てあると述へている。今回、上記鋼㮔の連続鋳造に ジルコニアーグラファイト（ZＧ）質イマージョンノズルを 用いたところ、上記 A G 筫に見られたような損傷は見られず 好結果を得た。本報では、これら2㮔の材質のステンレス鋼 による損傷のメカニズムについて橹討した。

2. 実験方法: A G , Z G 2 軼のイマージョンノズルを塞機 てのステンレス鋼の連続鋳造に用い、その使用後品の内孔稼 動面を顕微鏡およびE P M A で觀察することにより、その損 傷状態を比較した。

3。結果书よび考察：眓1 に実機使用後のAGおよびZGの 稼動面の概略図を、その中の丸で囲んだ部位の E P M A の特

Orlginal zone 性 X線像を写真 1 亿示す。

a) A G 稼動面：原 A G 層と変質屏との境界部は凹凸に富み 、 $2 \sim 10 \mu \mathrm{m}$ の微細な金属㔹その境界部や鳞状黒鉛に沿っ て見られる。その金属は主に $\mathrm{F}$ e ， C r ， N i などから成。

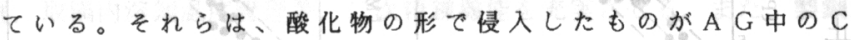
と反応し、Cを酸化させ自らは還元されてそこに付着したも のと思われる。

b ） Z G 稼動面：稼動面はジルコニアに富む酸化物層を形成 して戈り、その酸化物層の原 $\mathrm{Z} \mathrm{G}$ 層との境界部は $\mathrm{A} \mathrm{G}$ に比心 比較的平滑でる。その酸化物屏内には $2 \sim 10 \mu \mathrm{m}$ 程度の 微細な金属が見られるが原 Z G 層にまでは到達していない。

従って、ZGの場合は、稼動面にジルコニアに富む酸化物 Mn 層を形成して C r 酸化物のような酸化性の強い物質の原層 の侵入を防く為に变質しないものと思われる。

4。まとめ： A G 質ノズルとZ G 質ノズルをステンレス鋼の 連続鋳造に用い、その損傷状態を調查することによりC含有 ノズの損傷メカニズムを推定した。A G 質ノズルは $\mathrm{N}$ i， $\mathrm{F}$ e， C r などの酸化物によるCの酸化により損傷が進むが

、Z G 質ノズルは稳動面にジルコニアに富む酸化物を形成し 上記酸化物の侵入を防ぐことによって損傷が進まないものと 思われる。

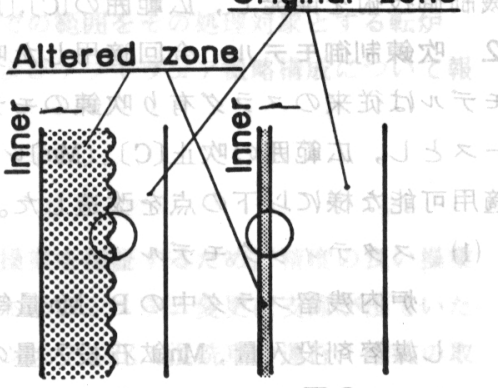

AG $\quad Z G$
Fig.1 Schematic View of Cutting

Surface of Used Nozzle

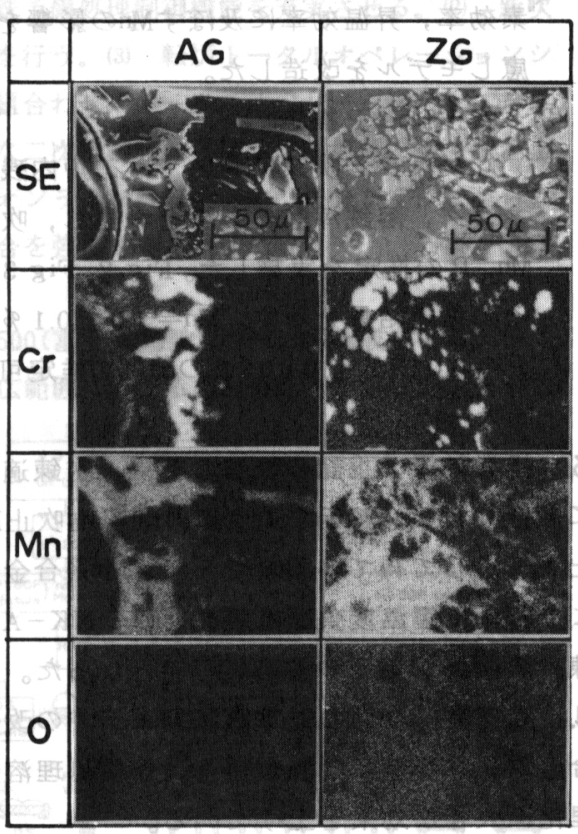

Photo.1 Characteristic X-ray Images of Used Nozzle (circled area in Fig.1)

(1)飯田ら第65 回造塊用耐火物專門委員会資料（1985） 
（266）予備処理溶銑吹錬の計算機制御

\section{日本鋼管㫼 京浜製鉄所 製鋼部 ○村木靖徳 石川博章 石川 勝 プロセス制御部 宮原弘明山田警}

1. 緒 言 京浜製鉄所では, 昭和 61 年 11 月に溶銑脱りん設備 ${ }^{1) 2}$ が稼動し, 転炉では 20 万 TON/月のレ ススラグ吹錬を実施しMn系合金鉄及び媒溶剤削減を行っている $\left.{ }^{3}\right)$ 今回, 高 Mn 溶湯吹鍊にも適用可能な計算 機制衔技術を開発し，広範囲の[C],[Mn]レベルでの吹鍊適中率向上を実施したので報告する。

2. 吹鍊制御モデル 今回適用した吹鍊制御 モデルは従来のスラグ有り吹鍊のモデルをべ ースとし，広範囲の吹止 $[\mathrm{C}],[\mathrm{Mn}]$ レベルでも， 適用可能な様に以下の点を改造した。(Fig 1)

(1) スタティックモデル

炬内残留スラグ中の P.Mn量等を考虑 し媒溶剤投入量, Mn鉙石投入量の精度了 ップを図った。

(2) ダイナミックモデル

高Mn溶湯の吹鍊においては,溶湯中のMn濃 度の変化を無視できない。そてで脱炭酸 素効率, 具温効率に及ぼすMnの影響を考 虑しモデルを改造した。

(3) 吹止 $\mathrm{Mn}, \mathrm{P}$ 推定

レススラグ吹鍊においては, 炉内残留 スラグ, 溶銑泽等の影䇾を考虑し, 吹止 Mn，Pの推定を実施した。Fig 2,Fig 3 亿 その推定結果を示す。 $\mathrm{Mn}=1.0 \pm 0.1 \%$ $\mathrm{P}=0.015 \% \pm 0.002 \%$ 範囲で推定可能 となった。

3. 操業結果上記の改善の結果, 吹錬適中率は大幅 に向上し, Fig 4V示すよ5に月間平均吹止 Mn $0.70 \%$ 以 上を安定して得ている。さらに, Mn系合金鉄の削減に より転炉出鋼温度負荷は軽減され, NK-AP（取鍋精 錬昇熱設備) 処理の省略が可能となった。

4. 結 言 今回の計算機制御モデルの改造により, 合金鉄, 媒溶剤の削減が進み, 予備処理溶銑吹鍊の合 理化に大をな効果を上げている。

\section{<参考文献 $>$}

1) 田畑ら：鉄と鋼 731987 S 271

3）村木ら：鉄と鋼 731987 S 218

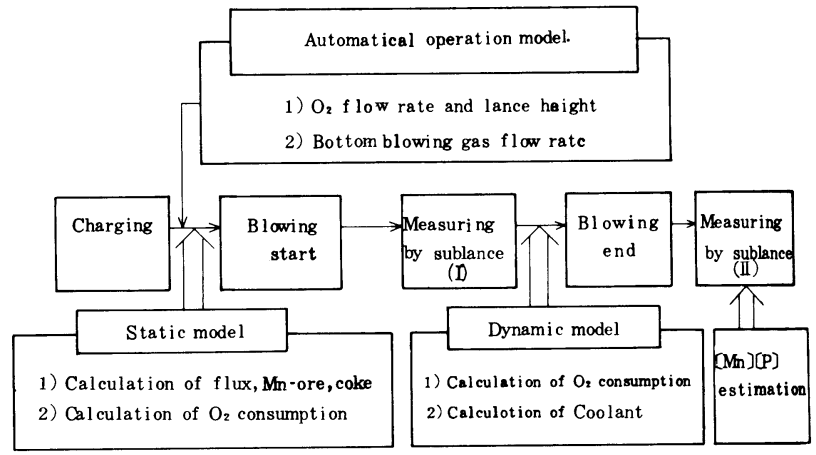

Fig.1. Computer controll system of less slag blowing
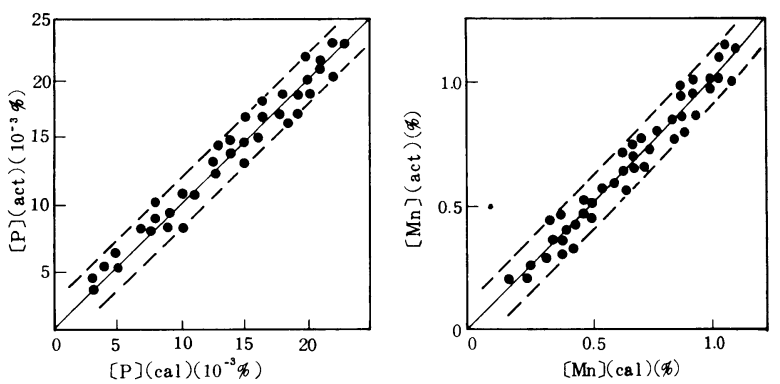

Fig 2. Estimation of [P]atE.P Fig 3. Es timation of [Mn]at E.P

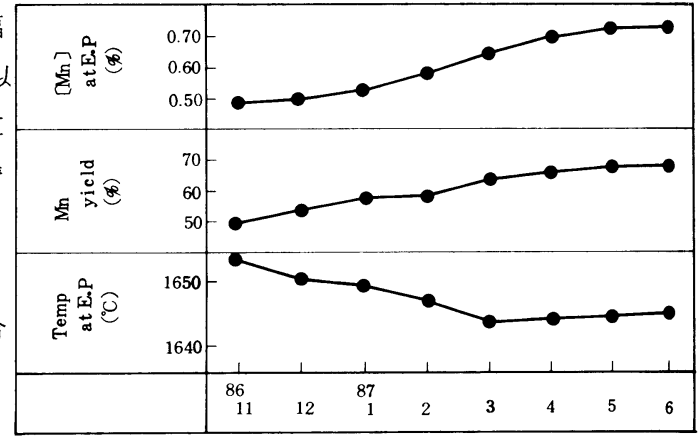

Fig 4. Operating results of less slag blowing 2）本講演大会発表予定 
水島転炬新プロセス計彩機システム

一転炉プロセス計算機更新 第 1 報一

川崎製鉄水島製鉄所

山根 明 岩村忠昭○刀根 功 三崎規生 平山勝久 上田 新

1. 緒言

製銑〜製鋼〜熱延の同期・連続化を目的とした新システムが，水島で1986年10月より稼動した。第 2 製鋼工場にお いても旧ブロセス計算機（以下P/C）を更新し，混銑車運行管理から二次精鍊までの範囲をその処理対象とする転炉 P/C システムを構築した。本報ては, 新システムの開発目的, ハードゥェアおよびソフトウェア概略構成について報 告する。

2. 目的およびシステム設計方針

以下に転炉P/C システム開発目的を示す。

(1) 製銑〜製鋼〜熱延の同期化操業への対応：嚴密に管理されたスケジュール操業を保証するため，精度の良い操業 管理をきめ細かく行う。(2) 既存計算機システムの老朽化への対応 : 安定稼動およびシステム変更に支障が出ていた 旧システムを更新し，高度な情報処理に対応可能とする。(3) 製銑〜製鋼間のシステム化：混銑車の運行，溶銑の取 投い等，従来高炬〜転炬の狭間にあり人間の勘と経䂆に委将られていた部分をシステム化することによりコストダウ ンを図る。(4) 操業形態の変化, 新技術への対応: 溶銑予備処理設備導入による溶銑品種の多様化, 上底吹転炉操業

等，操業形態の変化，あるいは新技術に対して制御モデルの更新等により制御精度の向上を図る。

以上を踏まえ、システム設計に当って以下の項目に重点を置いた。

(1) 溶銑シテスムの開発：混銑車運行管理システムの構築，および溶銑予備処理制御機能を充実させる。(2) 新吹 鏻制御モデルの開発 : 転炉の吹鍊制御に関する主要モデルの全面見直しを行う。(3) 転炉トータルオペレーションシ テスムの構築 : 既存のK-BOP CRT オペレーションシステム”と有機的に組合わせ,トータルオヘレレーションシステム を構築する。(4) 二次精鍊機能の充実, 連鋳 $\mathrm{P} / \mathrm{C}$ との結合の強化 : 複雑な二次精錬設備の操業情報処理, 合金鉄歩止 管理，取鍋内溶鋼温度管理等，二次精鍊機能を充実させる。また，製鋼オンライン計算機 $(0 / \mathrm{C})$ を介して，これらの 情報を連鋳 $\mathrm{P} / \mathrm{C}$ へ迅速に妘達することにより，連鋳 $\mathrm{P} / \mathrm{C}$ 処理との機能結合を強化する。

3.ハードウェアおよびソフトウェア構成

Fig.1 に転炉P/C システムのハードウェア全体構成を示す。CPUはS3500(富士電機製) のDuplex構成である。2) 本システムは，高炉での混銑車の受銑から製綱での二次精鍊完了までの広笔囲にわたる諸設備をその処理対象として いる。また、ソフトウェアは以下の 6 サブシス テムから構成される。1)混銑車運行管理，2)溶 予借処理制御，3）主原料段取制御，4）転炉吹 制御，5)二次精鍊制御，6)共通処理。言語は PORTRAN77 で総計125Kステップである。一部を 䣄て自社開発を行った。開発期間は， 2 年 5 ケ月である。

\section{4. 結言}

新システムは順調に稼動し，混銑車稼動台数 の削娍 ()，吹鍊モデルの精度向上等“，更新に よる効果が発揮されている。

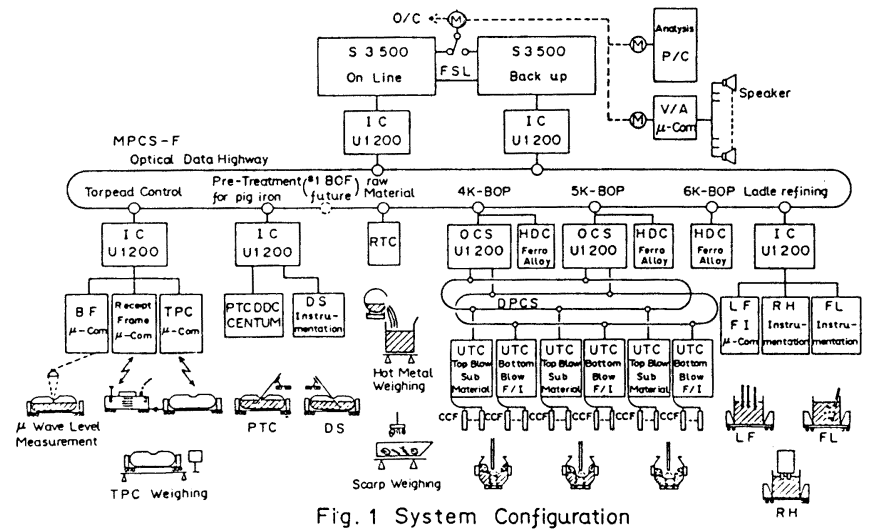
〈参考文献〉 1) A.Yamane et al；68th Steel Making Conference, AIME, April(1985) 2) '分散型計算機統括 制御システム特集'，富士技報，VOL. $57 ，$ No. 3, 1984 3 ) 三崎ら；鉄と鋼，73(1987)，S272

4) 刀根ら ; 本講演大発表予定 
' $87-$ S 1004

(268) 転炬吹錬制㱟モデル保守解析システムの開発 一転炉ブロセス計算機更新 第 2 報一

川崎製鉄水島製鉄所 ○刀根 功 山根 明 岩村忠略

三崎規生 小山内寿

\section{1. 緒言}

水島製鉄所では，2 製鋼転炉ブロセス計算機（以下P/C）の全面更新 ${ }^{1)} に$ 合わせて，吹鍊制御モデルも一新された。 これら各制御モデルの精度維持向上を目的として，セントラルコンピュータ（以下C/C) 上の操業情報データベース (以下D/B)を利用した保守解析シテスムを開発したので報告する。

2. 吹鍊制御モデル保守解析システム

\section{1 システム概要}

転炬操業においては，本質的に湘定あるいは定量化不可能 な要因が多く，吹鍊制御モデルには構造式の一部に統計モデ ルが操用されている。一般的に統計モデルは操業条件の変化 に対して弱い面があり，溶銑予備処理の導入等，多様化する 転炬操業に対応してモデルの精度維持向上を果たすためには 澵大な実操業デー夕を簡便に処理可能な保守解析システムが 必要不可欠となる。当所て開発した解析システムの特徽は, 以下のとおりである。(1) P/C 内のモデルを容易にシミュレー トでき，精度評価が可能。(2)統計解析バッケージ等, 技術計 算沉用解析ツールが使用可能。(3)操業方法が比較的良く変更 される転炉操業に対して, 追従可能なフレキシビリティを有 する。(4)モデル定期保守を簡便に行うため, フィルインザブ ランク式のマンマシンインターフェイスを保有。

2.2 保守解析システムの構成

Fig.1 に構成図を示す。本システムは，C/C 内の専用解析 ファイルを中心に構成される。以下に機能を示す。

(1)デー夕抽出部: C/C上のD/Bから所要データを抽出し, 解析 ファイルに格納する。(2)シミュレート演算部：解析ファイル に格納された実績情報等を用い，各モデルのシミュレート演 算を行い，結果を解析ファイルに格納する。(3)解析精度評価 部：抽出デー夕、およびシミュレート演算結果を用いてモデ ル精度評価, 統計解析を行う。

\section{3. 適用例}

この保守解析システムを用いて，静的制御モデルを解析し た結果をFig.2,Fig.3に示す。Fig.2 はシミュレート演算結 果後の解析ファイルから抽出したパラメータ(スラグ中の $\mathrm{T} \cdot \mathrm{Fe})$ の検証図の一例, Fig.3は熱バランス，酸素バランス両 モデルのパラメータ調整過程における精度推移である。本シ ステムの活用により，推定精度を大幅に向上させることがて きた。

<参考文献> 1) 山根ら; 本講演大会発表予定

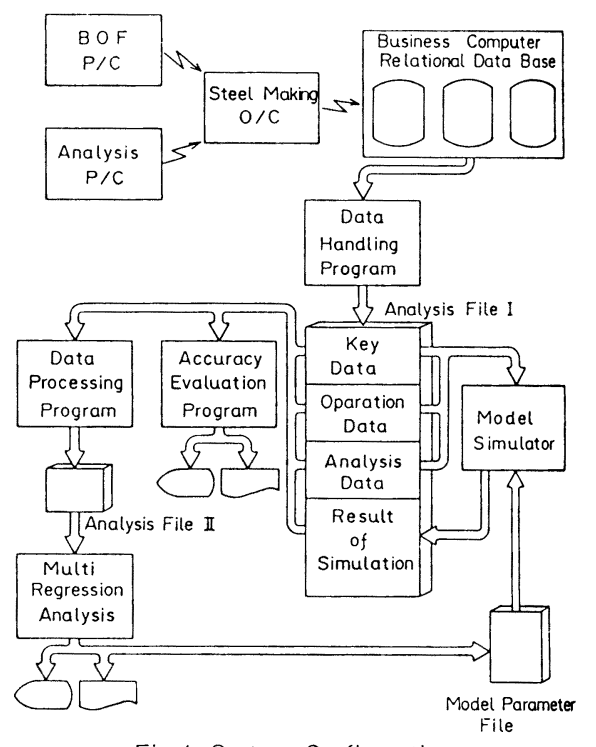

Fig. 1 System Configuration
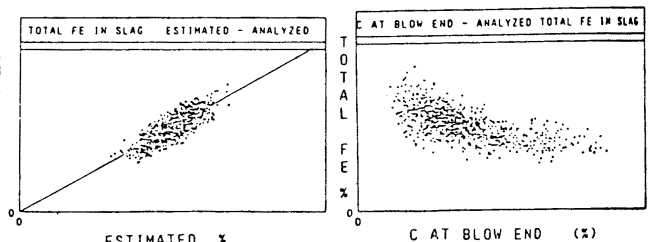

Fig. 2 An example of verification

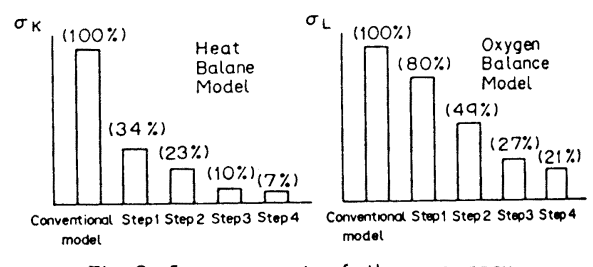

Fig. 3 Improvement of the accuracy (difference from the aimed accuracy) 
排ガス情報を利用した（ T. F e ）の推定

排ガス情報に基づく吹錬制御法の開発 - I

日本鋼管福山製鉄所竹腰篤尚橋本紘.吉 。畑中聡男

1. 緒 言

転炬吹鍊における終点 [ C ] 、温度の適中率は、スタティック制御技術とサブランス・ダイナミック制 御技術の応用で極めて高いレベルに到達した。しかし、近年の精鍊プロセスの多様化や、[ P ] 、 [ M n ] の制御の必要性から、終点制御に関し新しいアプローチが要求されている。当所では、ての二ーズに対 応する一つの方法として第2 製鋼工場に質量分析計を設置し、排ガス中の多成分の情報を迅速に処理す ることにより、炉内反応を連続的に推定する技術を開発した。その結果、今回スラグ中（ T. Fe ）を精度 良く推定可能となったので報告する。

2. 計測・制御システム

Fig. 1 亿計測・制御システムの概要を示す。ガス分 析計として、質量分析計( 8 成分同時連続測定、磁界 偏向形）を設置し、分析精度・伈答性の向上を図って いる。

3. ( T.Fe) 推定モデル

酸素バランスに基いて(1)式で定義された酸化度 $\left(\mathrm{W}_{2}\right)$ から(2) 式に従って、スラグ中（ T, F e ）在吹鍊中 連続して推定する。

$$
\begin{aligned}
W_{0_{2}}=[ & \int_{t}\left(f_{i}(Q, F)-f_{o}(V, A)\right) d t \\
& \left.-g\left(W_{p}, D\right)\right] / W_{M}
\end{aligned}
$$

$(\mathrm{T} . \mathrm{Fe})=\mathrm{h}\left(\mathrm{Wo}_{2}, a\right)$

$\mathrm{Q}$ ：吹錬酸素量， $\mathrm{F}$ ：副原料投入量

$\mathrm{V}$ : 排ガス中 $\mathrm{COCO}$ 量, $\mathrm{A}$ : 炉口巻込空気量

$\mathrm{W}_{\mathrm{p}}, \mathrm{Wm}$ : 溶銑, 溶鋼重量, $\mathrm{D}$ ：溶鉄中 $\mathrm{S}_{\mathrm{i}}, \mathrm{T}$ i 濃度

$a$ : 原料, 吹鍊条件で決まる定数

\section{4. 適用結果}

Fig. 2 に推定 ( T. Fe ) と実績 ( T. Fe ) の関倸を示す。推定 精度は、士1.5 \% 以内に 9096 以上拈さまっており、満足の いく結果が得られた。したがって上記モデルを用い、( T. Fe e ) を連続して推定するととによって、鋼種等によりヒート每に 決められている目標の (T.Fe)で吹止めることが可能となり、 終点 $[\mathrm{P}]$ の適中精度向上が期待される。

5. 結 言

質量分析計による排ガス情報から、炬内反応を連続的に推

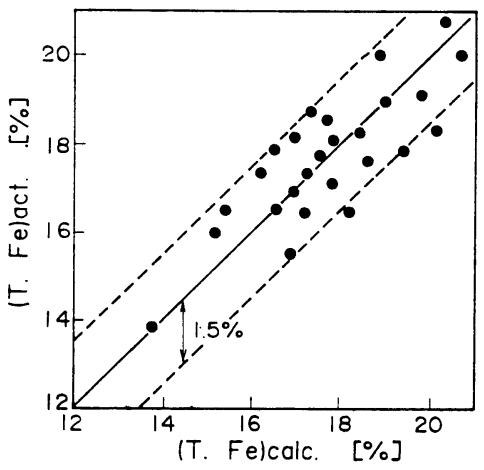

Fig.2 Relation between (T. Felcalc. and $(T$. Felact. at end point. 定できるシステムを開発した。ぞの結果、酸素バランスに基いて定義されたWor から（T. Fe ）を連続し て推定するととが可能となった。現在、Worを用いた終点制御の精度向上を推進中であり、従来より高 度な吹鍊制御技術の確立を目ざしている。 


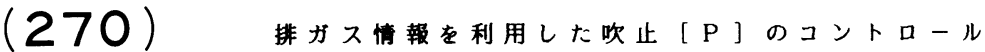

（抹カス情報に基つく吹䤠制御法の開発 2 ）

日本銅管（株）福山鉄所内田繁福味純一狛谷昌紀

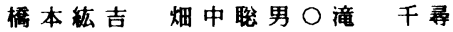

1. 緒言

転炬に於ける終点制御技術向上の一棵として、量分析型カス分析計を道入し、炉内反応在連繶的

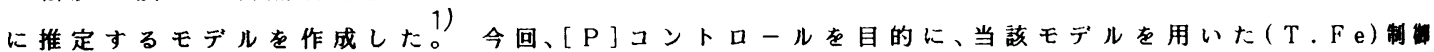
と、ヒート毎の媒溶用の適正化を図った。その結果、レードル[P]のばらつき低減及ひ媒溶詴の合理化 に効果があったので報告する。

2. 実操業への応用

2.1 媒溶都の適正化

Fig1に、媒溶郕決定モデルの概要を示す。媒溶用の適 正量は、ヒ一ト毎の目標（温度、( $\mathrm{T} . \mathrm{Fe}$ )、吹止 $[\mathrm{P}])$ に基 うき、理諭モデル(㙂りん平衡式等)から決定される。 この結果、目橑適中により、吹止 [P]の制御が可能と なっている。

\section{$2.2(\mathrm{~T} . \mathrm{F} \mathrm{e})$ の制御}

前報で示したとうり、排カス情報モデルを用いて吹鍊

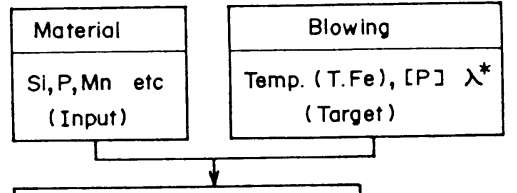

(1) Eq. Dephosphorization (2) Eq. Slag balance (3) Eq. [P] balance

$\lambda^{*}:$ Equilibrium attainment of dephosphorization

Fig.l Theoretical model of flux calculation 中に( T.F e ) レベルが認瀐可能となった。この結果 目標 ( $\mathrm{T} . \mathrm{Fe}$ ) レベルでの吹止が可能となり、( T.Fe)のばらつき が低減し、かっ平均レベルも低下させることができた。（Fig2）

\section{$2.3[\mathrm{P}]$ の制御}

Fig.3に、レードル[P]の分布を示す。上記モデルを道用した結果、 媒溶用原単位及び吹止時の $(\mathrm{T} . \mathrm{Fe})$ の適正化がはかられ、レード ル[P]のばらつきが低隇出来た。また、この結果レードル[P]の平 均レベルを規格に対し道正とすることが可能となった。これにより 媒溶都原単位が約 $4 \mathrm{~kg} / \mathrm{t}$ on削減出来た。(Fig 4)

一方、本モデルの適用により、従来吹止 [P]推定のために実施して いた測酸プローブによる吹止测酸も不要となった。

\section{3 . 結 言}

寊量分析計を利用した排ガスモデ ルによる、( $\mathrm{T}, \mathrm{F}$ e $)$ 推定と、媒溶郕の 道正制御の組合せにより、吹止 [P] が安定し媒溶郕の合理化等の效果が 得られた。

\section{〈参考文献〉}

1）㚼中ら、本㳟演大会発表予定.

2) 碓井ら、鉄と銅 68(1982)S228

3）丹村ら、鉄と鋼 69(1983) S 1003

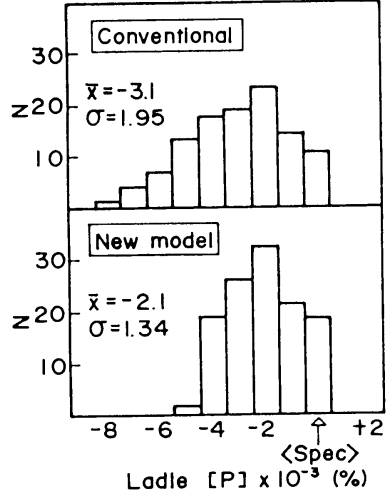

Fig.3 Distribution of ladle $[P]$

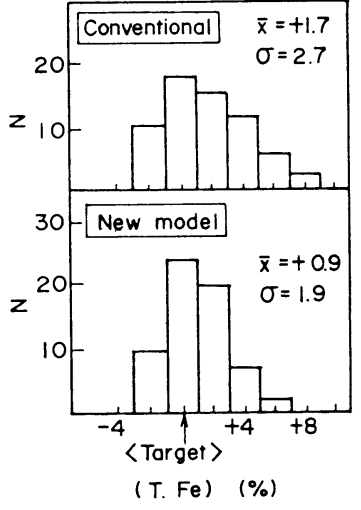

Fig.2 Distribution of ( $\mathrm{T}$. Fe)

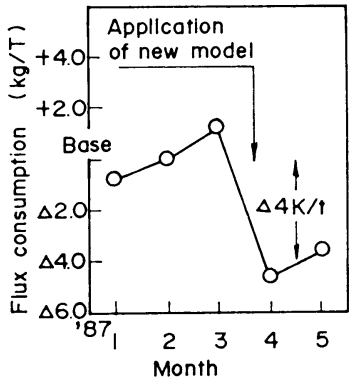

Fig.4 Change of flux consumption (Except less slag blowing) 


\section{（271）転炉スラクカット技術の実用化}

\section{（株）神戸製鋼所 加古川製鉄所副島利行 小林潤吉 松井秀雄}

\section{森川敏男 大数敏雄 $\mathrm{O}$ 前田真一}

1. 粕言転炬出鋼末期の取鍋へのスラグ流出防止は、合金眖酸剤の歩留向上, 復りん防止, 取鍋耐 火物溶損防止などに留まらず、溶鋼品質の安定化に不可欠な技術になっており、てれまでボール方式 ${ }^{11}$ 投射機方式 ${ }^{2)}$ ストッパー方式 ${ }^{3)}$ など多くの方式が開発，実用化されている。今回、出銅孔外部からガス噴

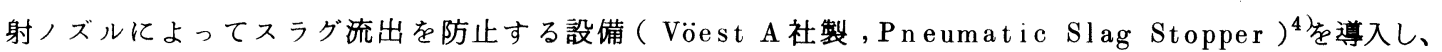
良好な操業結果が得られたので以下に報告する。

2. 設䧿概要設備の概要と主仕嵄孝 Fig.1 亿示す。当設 備は出鋼末期にスイングァームの作動と同時に、ガスを噴射 させながら出鋼孔を閉塞する本体設備と、噴射ガスおよびシ リンダー作動, 本体設備の冷却保護などに必要なガス供給設 備から成っている。

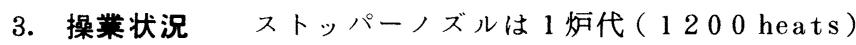
交換する必要がなく、設備稼動率ははは100\%を達成してい る。スラグカット時の取鍋内スラグ厚は、目視による流出判 断で従来より粎 $60 \mathrm{~mm}$ 減少し、平均 $60 \mathrm{~mm}$ になっている。

Fig.2は大型介在物量におよばす転炬流出スラグの影響を 示したもので、酸化性スラグの減少により介在物品質の改善 が図れた。またFig.3には取鍋スラグライン部耐火物の溶損 速度におよぼす影響を示す。耐火物溶損は単に流出スラグを 少なくするだけでははとんど効果はないが、スラグカットと 焼成ドロマイトの併用により、スラグ組成をコントロールす るととで耐火物溶損速度の改善に効果が得られた。

このほか A l , S i , Mn など合金脱酸剤の歩留向上, 復りん の防止についても効果が確認された。

4. 結言転炬スラグカットの実用化をはかり、取鍋への 流出スラグ量を低减した結果、鋼中介在物の減少，取鍋耐火 物溶損速度の改善, 合金鉄の歩留向上, 復りん防止などの効 果が得られた。

\section{文献}

1)王寺ら；鉄と鋼，63（１９７７），S130

2)沢村 万；鉄と鋼，63（１９７７），S 131

3)日新製鋼（私信），(1983)

4) M.Eysn : Iron and Steel Engineer

October ( $\left.\begin{array}{llll}1 & 9 & 8 & 3\end{array}\right)$, P 53

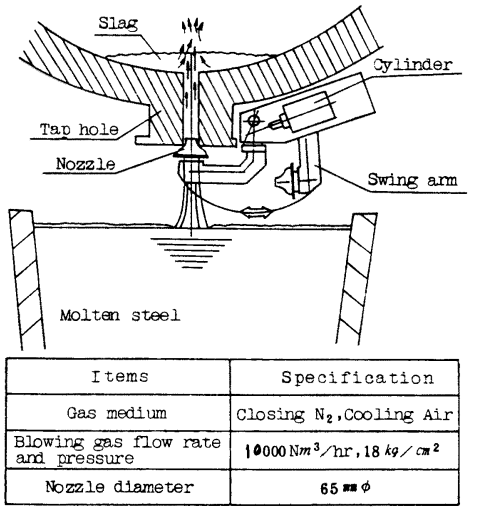

Fig.1 Schematic view of slag stopper equipment with main specification

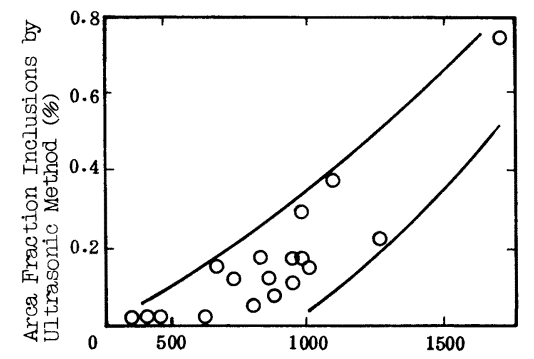

$(\mathrm{T} \cdot \mathrm{Fe})(\%) \times \mathrm{Thickness}(\mathrm{mm})$ of Ladle Slag Fig.2 Effect of flowed out converter s lag into ladle on content of large inclusions in steel

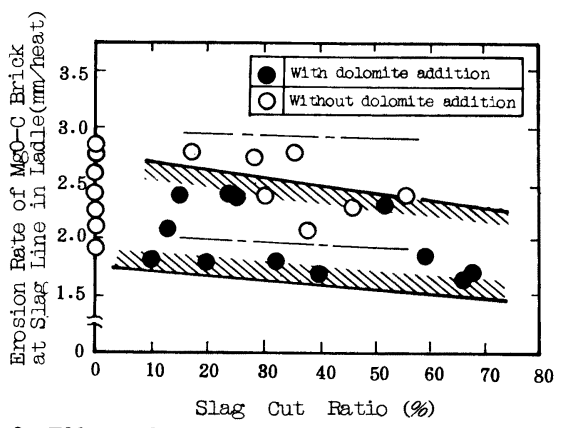

Fig.3 Effect of slag cut on erosion rate of $\mathrm{MgO}-\mathrm{C}$ brick at slag line in ladle 
（272）転炬内スラクの固化によるスラク流出防止法の開発

\begin{tabular}{|c|c|c|c|c|}
\hline 新日本裂（株） & 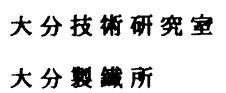 & $\begin{array}{l}{ }^{\circ} \text { 山村 } \\
\text { 矢倉 }\end{array}$ & $\begin{array}{l}\text { 英明、金子 } \\
\text { 重籍 、工博 }\end{array}$ & $\begin{array}{l}\text { 數行、三明 } \\
\text { 長田次 }\end{array}$ \\
\hline
\end{tabular}

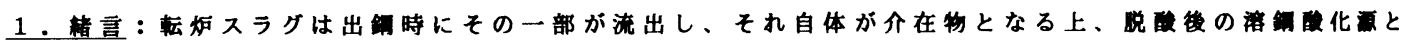

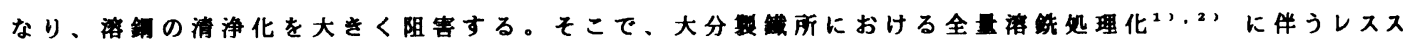

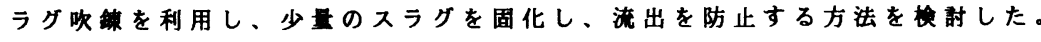

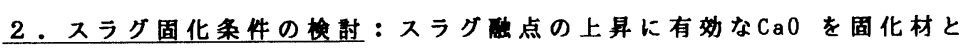

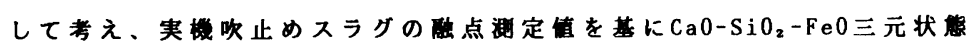
图の洨相缭温度を補正し、Ca0 添加後のスラグの点を推定した（Fig.

1)。これによると、 $\mathrm{CaO} / \mathrm{SiO}_{2}$ の上㫒、 $\mathrm{T} . \mathrm{Fe}$ の減少に伴って点が上界す る。又、転炬内スラグを固化するには、監点を少なくとも転炬処理沮度 より高くする必要があるが、そのためにはT.Feが15\%のスラグではCa0/ $\mathrm{SiO}_{2}$ を粎 4.5 以上碓保しなけれはならないことが判る。

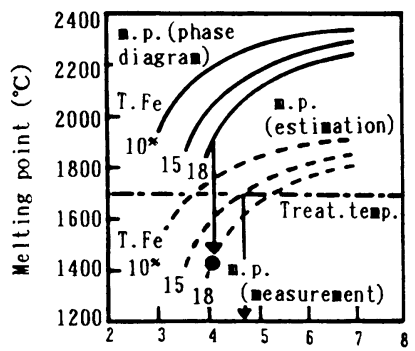

$\mathrm{Ca} 0 / \mathrm{SiO}_{2}$

Fig. 1 Estimation of solidify-

ing condition of slag.

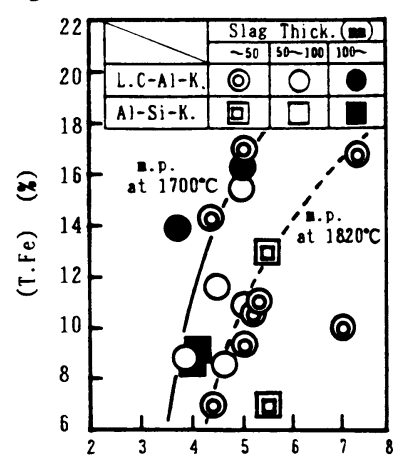

$\mathrm{CaO} / \mathrm{SiO}_{2}$

Fig. 2 Effect of composition on the thickness of ladle slag. ラグ厚が提来に比べて激減する（Fig，3）。

一方、スラグ固化により取溜全中の介在物量が安定して低減してい る(Fig，4)。これは固化により、流出するスラグが減少するとともに、

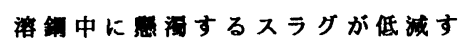
るためと考えられる。

5.桔葍：レススラグ吹镜におけ る少量スラグを $\mathrm{Ca} 0$ で固化し、ス ラグの流出を防止するともに、溶 鋏の清浄性が大幅に向上した。

參考文盛：1）竹村洋三ら; と鋾, 73(1987), S277。2) 山本

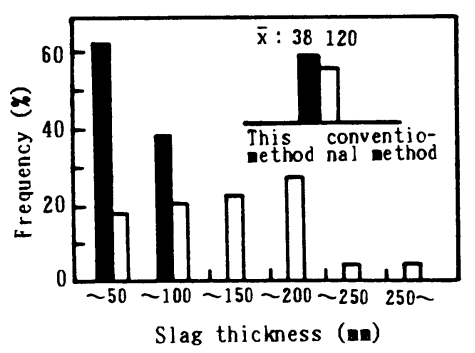

Fig. 3 Effect of $\mathrm{CaO}$ addition
利樹ら; と錯, 73(1987), S278. on the thickness of ladle slag.

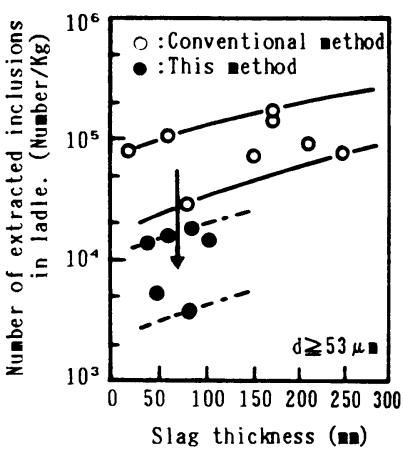

$\mathrm{Fig.4}$ Effect of $\mathrm{CaO}$ addition 


\section{1. 緒言}

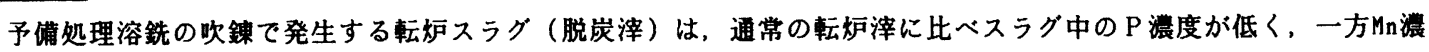
度が高い。そのため，この脱炭㳯を普通鉄吹鍊に使えば，脱 $\mathrm{P}$ 能力に余裕があり，また吹止Mn湦度の增大にも有効で ある。脱炭涬を積極的に普通銑吹鍊に利用した結果, 造涬剂原単位の削減, 吹止Mn溄度の向上に大きな効果が得られ た。

\section{2. 脱炭澾使用による造涬剂削減の検討}

脱炭㳯の $\mathrm{P}_{2} \mathrm{O}_{5}$ 洤度は転炬㳯のそれの約 $50 \%$ 程度であるた めに，脱炭澾は普通銑吹銤で，脱 $\mathrm{P}$ 能を有するスラグとし て働き石灰原単位の削娍が可能である。また，Mn0 隂度に ついては，転炬涬に比へ約 $45 \%$ 高いため吹止Mn漕度の增大 が期待できる。

脱炭㳯を使用すると，Fig.1 に示すように脱炭㳯中に含 まれる $\mathrm{P}$ のためにインプット $\mathrm{P}$ が增加し， $\mathrm{P}$ バランスから 計算される必要スラグ量は增大する。しかし，脱炭涬中の $\mathrm{Ca} 0, \mathrm{Mg} 0$ 量により，脱炭涬 $1 \mathrm{~kg} / \mathrm{t}$ あたり焼石灰 $0.21 \mathrm{~kg} / \mathrm{t}$, ドロマイト $0.11 \mathrm{~kg} / \mathrm{t}$ の削減が可能でる。

\section{3. 実鵌結果}

脱炭㳯を炉内に残すこと，および排涬された脱炭㴖を冷 間で回収し，破碎後転炬へリサイクルすることにより脱炭 涬の有効利用を図った。脱炭㳯を炉内に残す場合は10 20 $\mathrm{kg} / \mathrm{t}$ 残し、リサイクルした脱炭㳯を使用する場合は，10〜 $25 \mathrm{~kg} / \mathrm{t}$ 用いた。

Fig.2 にP 分配比とT.Feの関係を示す。脱炭㳯を使用す ることにより，通常レベルに比べ $\mathrm{P}$ 分配比が上昇した。こ れは、脱炭㳯がすでにプリメルトされたものであるので， 㳯化を促進した効果によるものと考えられる。

また，脱炭㳯の冷却能は，焼石灰の約 $74 \%$ 程度と小さい ために，熱消費コストから見ても副原料コスト低減により 十分なメリットが得られた。

Fig.3 に的歩留と吹止 C 峘度の関係を示す。图より明ら かなように, Mn歩留は約10\%向上した。

\section{4. 結言}

脱炭㳯を有効に活用することにより，造㳯剂原単位削減， Mn歩留向上等の効果が得られた。

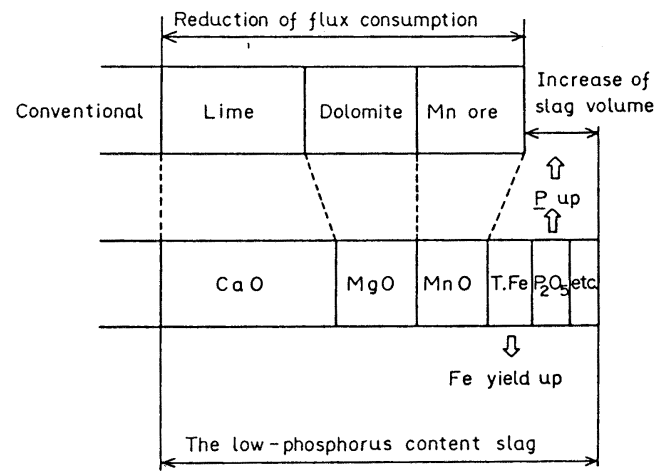

Fig.1 Schematic diagram of reduction flux consumption

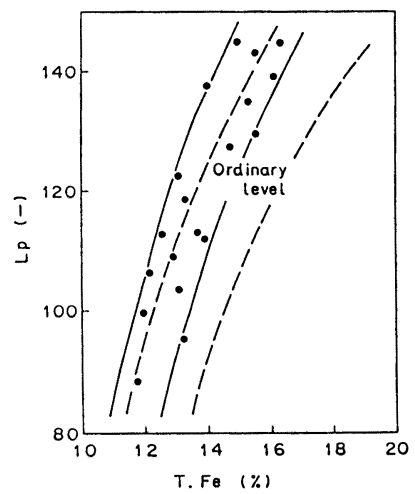

Fig. 2 Relation between phosphorus partition ratio and $\mathrm{T}$. Fe in slag

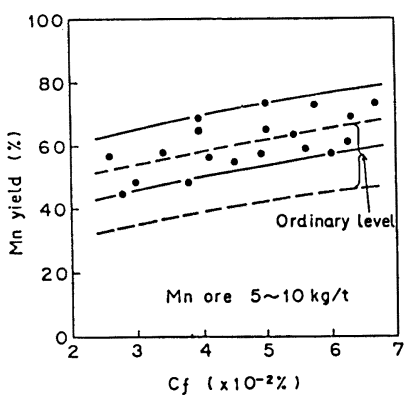

Fig. 3 Relation between $\mathrm{Mn}$ yield and (C) at end point 
(274) 脱接スラグの消和性とその利用

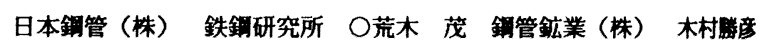

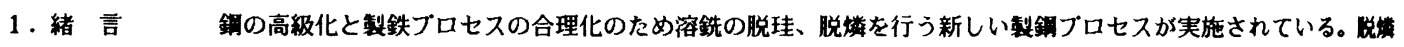
時に発生するスラグは、従来の製鎙スラグとは異なった性状を示すものであり、その有効な利用が望まれる。ここでは、その一つと して、温水による消和性を利用して有効成分を分離回収することを検討した。

2. 実験方法実験に用いたスラグの化学組成例を表 1 に、またX R D で同定され た鉣物から推定した鉱物組成を表 2 に示す。スラグは、1 $5 \mathrm{~mm}$ アンダーに破砕したも の（0.1 mmアンダー2 w t \%以下）を用い、図1に示すフローで実験を行なった。

Table 1 Chemical composition of slag (wt\%)

\begin{tabular}{|l|l|l|l|l|l|l|l}
\hline $\mathrm{CaO}$ & $\mathrm{SiO}_{2}$ & $\mathrm{P}_{2} \mathrm{O}_{5}$ & $\mathrm{~F}$ & Free $\mathrm{CaO}$ \\
\hline
\end{tabular} \begin{tabular}{|l|l|l|l|l|}
\hline 63.93 & 9.78 & 7.36 & 6.67 & 19.29 \\
\hline
\end{tabular} 消和は固液比 $1: 5$ （重量比）、9 $5^{\circ} \mathrm{C}$ 温水中で所定時間摬䢁することにより行なっ た。消和したスラグは乾燥後磁選し篩分を行ない $0.1 \mathrm{~mm}$ 通過量で消和性を評価した。 消和性を評洒したスラグは、希酸に対する $\mathrm{C} \mathrm{a} \mathrm{F} 2$ と他の鉱物との溶解性の差1により それぞれを分離することにした。希酸としては、H N O $10 \mathrm{w} t \%$ 溶液を用い、固液比 $1: 20$ (重量比)で 20 分間挩䢁处理したのち、ろ過により固液を分離して回収 物（以下これを回収物 I と称す）を得た。さらにろ液に $\mathrm{Ca}(\mathrm{OH})_{2}$ を加えてpH 10 として、生成した沈殿 物をろ過し回収物（以下回収物 II）を得た。

Table 2 Mineral composition of slag(wt\%) \begin{tabular}{|c|c|c|c|}
\hline $\mathrm{Ca} F\left(\mathrm{PO}_{4}\right)_{3}$ & $3\left(3 \mathrm{CaO}_{2} \mathrm{SiO}\right) \mathrm{CaF}_{2}$ & $\mathrm{CaF}_{2}$ & $\mathrm{CaO}$ \\
\hline 26.13 & 41.36 & 7.45 & 19.29 \\
\hline
\end{tabular}

3. 結果と考察 図 2 加3時間以降 の微粉（0.1 mm通過量）の発生はき わめて少なく、消和時間は 3 時間で十分 であることがわかる。図3に消和時間を 3時間とした時の Free CaO含 有量と消和性の関係を示す。 F r e e C a O含有量が減少するに従って消和し 難くなり、 $4 \mathrm{w} \mathrm{t} \%$ \%下ではほとんど消 和しない。表 1 に示すスラグから回収し たメタルは $25 \mathrm{w}$ t \%であり、スラグの 付着はほとんどないむのであった。メ夕 ル回収後のスラグを処理して得た回収物 I、IIの化学組成から、酸处理により

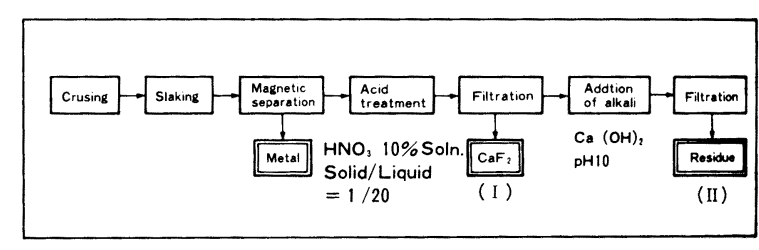

Fig. 1 Schematic diagram of the experiment

$\mathrm{P}_{2} \mathrm{O}_{5}$ 分の少ない $\mathrm{CaF} 2$ が高灌度で回収できること（回収物 $\mathrm{I}$ ）、回収物 II には $\mathrm{P}_{2} \mathrm{O}_{5}$ 分が濰縮されて回収できることがわかった（表 3 ）。

4. 結 言 脱燐スラグは F r e e C a O含有量により消和性が異な る。消和性を生かせばスラグ付着量のすくないメタルが回収できる。また酸処 理により $\mathrm{CaF}_{2}$ と $\mathrm{P}_{2} \mathrm{O}_{5}$ 分を分離回収でき、 $\mathrm{C} \mathrm{a} \mathrm{F}_{2}$ はリサイクル等、 $\mathrm{P}_{2} \mathrm{O}_{5}$ 分 は肥料原料への利用が期待される。

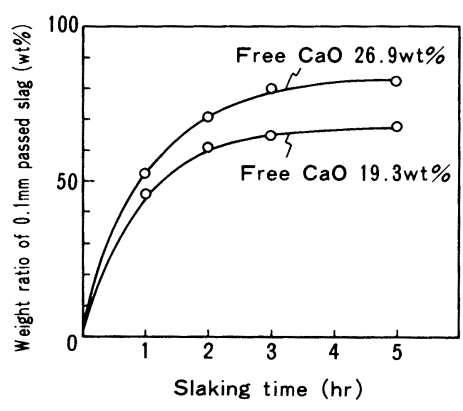

Fig. 2 Slaking property of slag

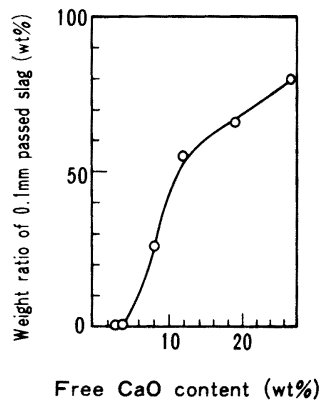

Fig. 3 Influence of Free $\mathrm{CaO}$ content on slaking

Table 3 Chemical composition of recovered material (wt\%)

\begin{tabular}{|c|c|c|c|c|}
\hline & $\mathrm{CaO}$ & $\mathrm{SiO}$ & $\mathrm{P}_{2} \mathrm{O}_{5}$ & $\mathrm{~F}$ \\
\hline $\mathrm{I}$ & 70.94 & 0.08 & 0.03 & 43.71 \\
\hline II & 35.06 & 22.75 & 21.64 & 6.85 \\
\hline
\end{tabular}

I:recovered material by acid treatment II: recovered material by addition of alkali 


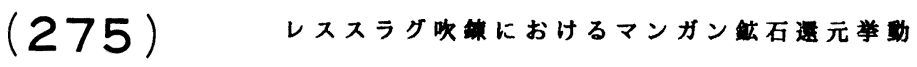

' $87-\mathrm{S} 1011$

（レススラグ吹技揞の開発第 1 報）

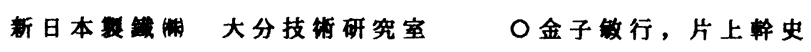
大分整践所工博長田管次, 竹村洋三

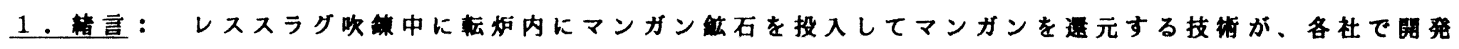

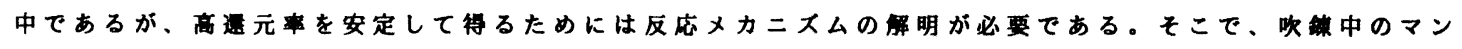

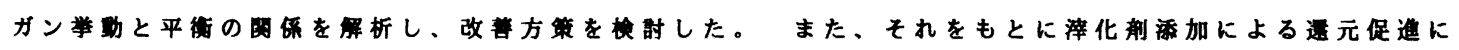

間するラボテストを実施した。

2.本炬内マンカン平衡に的する蜼：

2.1 吹能中の平街 $[\mathrm{Mn}]$ の变化と実楼との対応

吹凯中の[C]および沮度の变化に伴う平行 $[\mathrm{Mn}]$ 值の変化を、 (1)式の反応を前提として求めた。その䊀果をFig.1に示す。

なお、 $\mathrm{MnOの}$ 活量は吹止スラグ粗成から求めた 0.25 を使用 し、吹掽中は一定と仮定した。

$(\mathrm{MnO})+[\mathrm{C}]=[\mathrm{Mn}]+\mathrm{CO}$

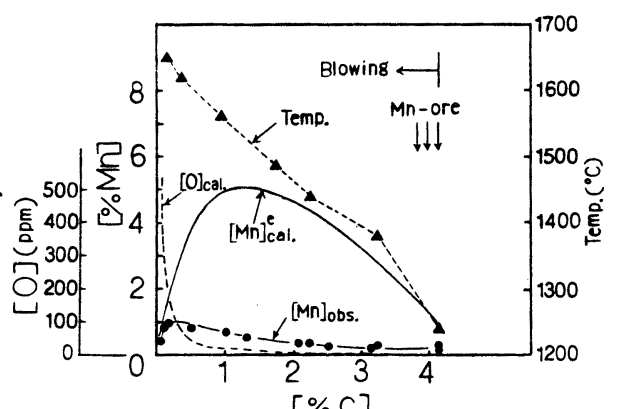

吹前半ては、平䚘 [Mn]は浴温の上㫒と共に增加し、[C] Fig.1 Change of [Mn]ecal and [Mn]obs during bloving. が $1 \%$ 付近で最大となる。それより低[C]湖の吹锞末期では、[O］の

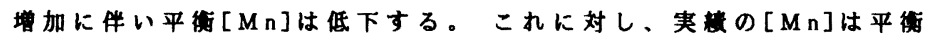
[Mn]より通かに低い值で推移しており、ピーク位至は長時间何にシ フトしている。このことから、吹鍊全体にわたって、マンカンの遇元 速度は椣めて遈いことが判る。

\section{2 吹止におけるマンカン平街}

吹止 [C]と吹止 $[\mathrm{Mn}]$ の闺 你を、平得值と対応させてFig. 2 に示す。吹止 $[\mathrm{Mn}]$ は $[\mathrm{C}]$ が 0.12 〜0.14\%で最大となっている。それより高[C]佃では平䚘[Mn]值が 浴中 $[\mathrm{Mn}]$ よりはるかに高いために遭元反応が進行し、低 $[\mathrm{C}]$ 㑡では

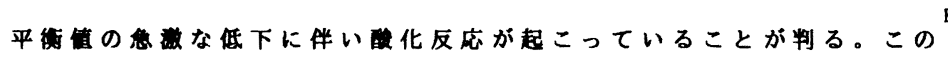
ように、吹止時点においても高 $[\mathrm{C}]$ 晸では平䚘值との隔たりが大きい ことより、スラグ㳯化が不十分であることが考えられたので、祡力学 的に固波平得部点を行い、吹此スラクの固相率を計算したところ、 $10 \sim 30 \%$ の高い值が得られた。

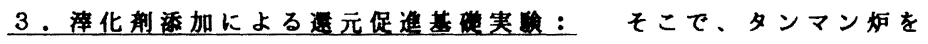
用いてFig.1に示した平街 $[\mathrm{Mn}]$ が取大となる条件下で、CaFa，

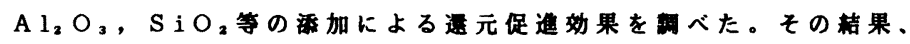
Fig.3に示すようにCaFa奻果が大をいことが判明した。

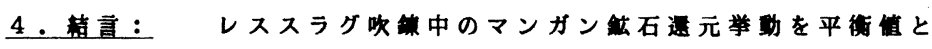

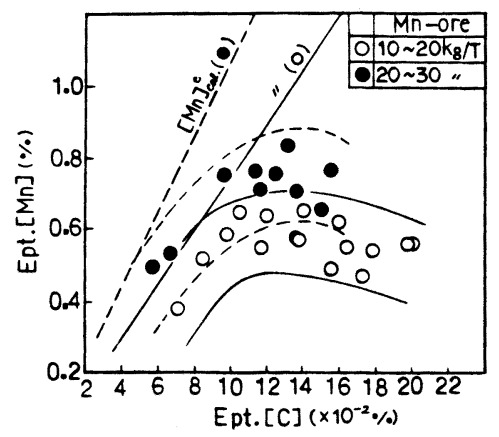
Fig. 2 Relation between Ept[C] and Ept[Kn].

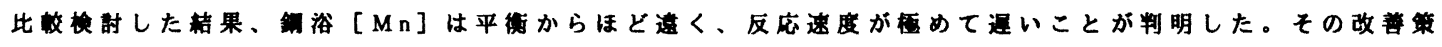
として CaFaによる涑化有圽であることをラボテストにより碓现した。

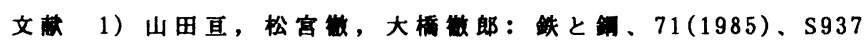

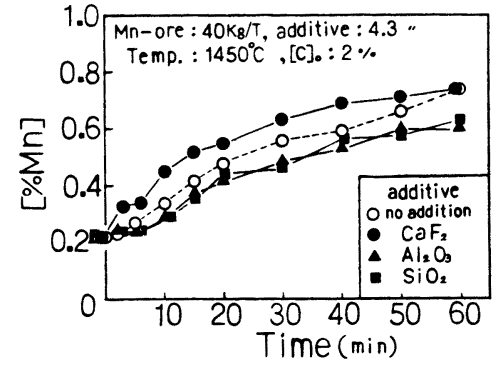

Fig.3 Effect of various additives

on Manganese reduction. 


\section{1. 緒 言}

大分製鐵所においては、昭和 61 年 6 月、O R P - M ( 全量溶銑予備処理設備) が稼動を開始し、脱 $\mathrm{S}$ i 脱 $\mathrm{P}$ を機能分割する事で、転炉工程は、脱 C と $\mathrm{Mn}$ 還元を目的としたレススラグ $\mathrm{Mn}$ 鉱石高還元吹 鍊を実施している。今回その操業概要について報告する。

\section{2. 吹鍊条件}

O R P - M 亿よる予備処理溶銑の吹鍊条件を T a b 1 e 1 亿示す。 レススラグ吹鍊末期におけるスラグ中 $\mathrm{T} ・ \mathrm{~F}$ e 低隇の為、底吹摚拌 力の強化や、末期ランスギャップの低減等に依り、上底吹擋拌の最適 化を図っている。また、炉内スラグ量を低減させ、高 $\mathrm{M} n$ 步留を得る

Table 1.Blowing conditions. 為、炉内投入副原料は、塩基度調整用生石灰のみとした。

\section{3. 結 果}

3. $1 \mathrm{M} \mathrm{n}$ 鉱石の還元促進

$\mathrm{M} n$ の還元は、

(1) $\mathrm{Mn}$ 鉱石の溶解溶触： M n O ( 鉱石 $) \rightarrow(\mathrm{MnO})$

(2) $(\mathrm{MnO})$ の嚐元 : $(\mathrm{MnO})+[\mathrm{C}] \rightarrow[\mathrm{Mn}]+\mathrm{CO}$ の 2 段階で進行する。Fig. 1 に吹錬中の温度と M n の挙動を示す。 $\mathrm{Mn}$ 步留向上の為には吹鍊中の浴温を高く保持する事により、M n 鉱 石の溶解及び還元を初期から促進させる事が有効である。

また、易溶解性の M n 鉱石の採用、初期溶解溶融を促進させるため の媒溶材 (ホタル石) 少量添加、吹鍊パターンの改良等により、Fig. 2 亿示す様に、M n 鉱石の多量投入にかかわらず高い $\mathrm{Mn}$ 步留を得た。 $3.2\lceil\mathrm{Mn}$ ○酸化防止

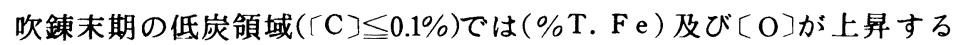
為上記(2)の反応と同時に (3): $[\mathrm{Mn}]+(\mathrm{FeO})=(\mathrm{MnO})+[\mathrm{Fe}]$,(4) $[\mathrm{Mn}]+[\mathrm{O}]=$ $(\mathrm{MnO})$ のnの酸化反応が優位となり浴中 $[\mathrm{Mn}]$ は低下する。乙の為、前 述のスラグ $\mathrm{T} \cdot \mathrm{Fe}$ 低隇対策の他、高 $\mathrm{Mn}$ 鋼種では、吹止 $[\mathrm{C}]$ 目標值を 0.10 \%以上とし、必要に応じて R H - O B にて脱炭するという機能分担を 実施している。てれらの方法によりFig. 3 に示すように 吹止 $[\mathrm{Mn}] \geqq 1.5 \%$ が可能となった。

\section{4. 結 言}

予備処理溶銑を用いたレススラグ吹錬において、M n 鉱石の溶解溶 融促進、M $\mathrm{n}$ 酸化防止対策により、M n 鉱石多量投入、高 $\mathrm{M} n$ 步留に よる、高い吹止 $[M n]$ 得る事が可能となった。

文献 1 )金子ら : 本講演大会発表予定

\begin{tabular}{|ll|}
\hline LD-OB Capacity & $340 \mathrm{Ton} / \mathrm{ch}$ \\
Oxygen flow rate & 45000 \\
& $\sim 73000 \mathrm{Nm}^{3} / \mathrm{Hr}$ \\
Bottom stirring & $0.15 \mathrm{Nm}^{3} / \mathrm{min}^{\mathrm{T}} \mathrm{Ton}$
\end{tabular}
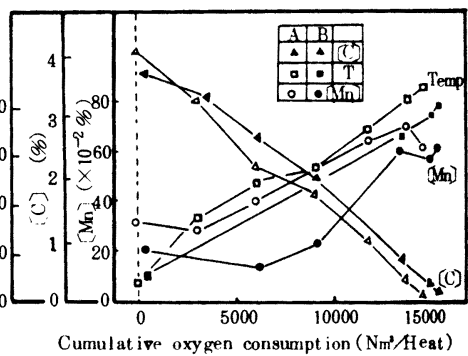

Fig. 1. Behavior of components during a blow detected by sub-lance sampling.

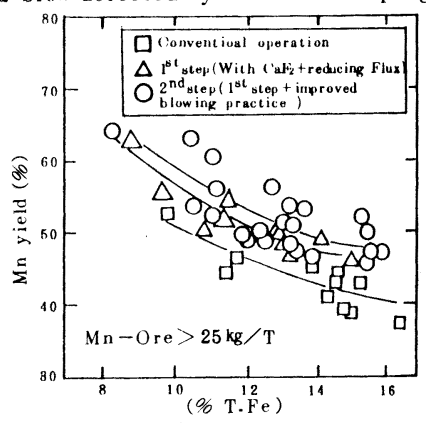

Fig. 2. Influence of blowing practice on $\mathrm{Mn}$ yield.

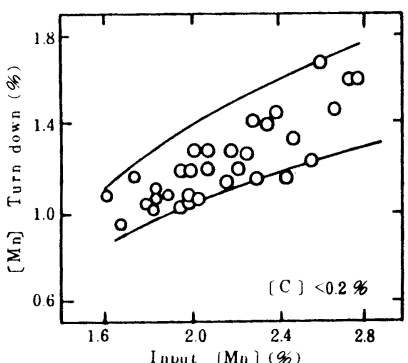

Fig. 3. Relationship between Input $(\mathrm{Mn}$ ] and [Mn] Turn down. 


\section{（277） レススラグ吹鍊における吹止 $[\mathrm{Mn}]$ 向上技術}

' $87-$ S 1013

住友金属工業(㑣) 鹿島製鉄所 吉田克磨 山崎 熏 田中雅章

青木伸秀 ○渡辺吉夫

I. 緒 言

当所では $250 \mathrm{~T}$ 複合吹錬転炉を用いた脱りん法、SRP (Simple Refining Process)が本年 1 月

より順調にオンライン稼働している。今回、脱りん鉄のレススラグ吹鍊において、高いMn歩留を得る ための条件につレて検討したので報告する。

II. Mn 歩留向上 対策

1. ( T 。 Fe) の低減

Mn步留を向上させるために、Fig.1 に示すような上 底吹をパターンを採用し、脱炭速度と送酸速度をバラ ンスさせることによって、 $\mathrm{FeO}$ の生成を抑制した。

2. Mn鉱石の溶融還元促進

大量に投入するMn 鉱石の溶融を吹止までに完了さ せるため、以下の対策を講じた。

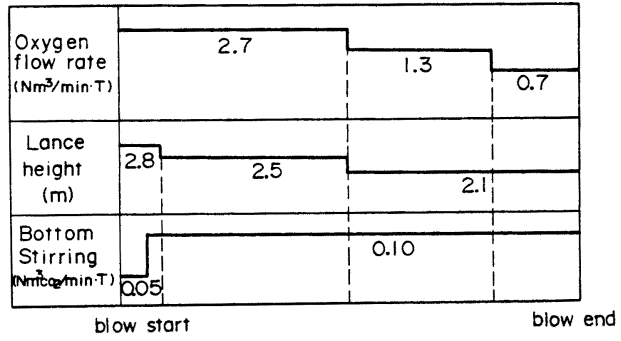

Fig.l Blowing condition

1) 吹鍊開始直後に全量投入し還元時間を確保する。

2)初期スラグを低塩基度化( 1.0$)$ し溶融促進を図る。

III. 操業結果

Fig. 2 に吹止 [C]とMn歩留の関係を示す。中炭素 高 $\mathrm{Mn}$ 鋼を対象に前述の対策を採った結果、Mn步留が 約 $10 \%$ 向上した。従来 $\mathrm{Mn}$ 鉱石投入量の増加に伴い、 鉱石の溶け残りと考えられる不明分が增大寸る傾向 にあったが、溶融促進を図った結果、不明分が半減 した。(Fig. 3 )

また、S R Pによる脱りん銑は処理後温度が比較 的高いため、熱源を用いなくてる高い吹止 [Mn]值 が得られる。(Table 1)

N. 結 言

S R P 法による脱りん銑を用いたレススラグ吹錬 において、安定して高いMn 歩留が得られる技術を 開発した。

Table 1 Typical condition of treatment

\begin{tabular}{|l|c|}
\hline Hot metal temp. & $1300 \sim 1320^{\circ} \mathrm{C}$ \\
\hline Top. temp. & $1650 \sim 1670^{\circ} \mathrm{C}$ \\
\hline $\mathrm{Mn}$-Ore & $17 \sim 20 \mathrm{~K} / \mathrm{T}$ \\
\hline $\mathrm{Mn}$ yield & $65 \sim 75 \%$ \\
\hline$[\mathrm{Mn}]$ E.P. & $0.70 \sim 0.80 \%$ \\
\hline$[\mathrm{C}]$ E.P. & $0.08 \sim 0.12 \%$ \\
\hline
\end{tabular}

〈参考文献〉 1)吉田ら：鉄と鋼, 73 (1987), S 275

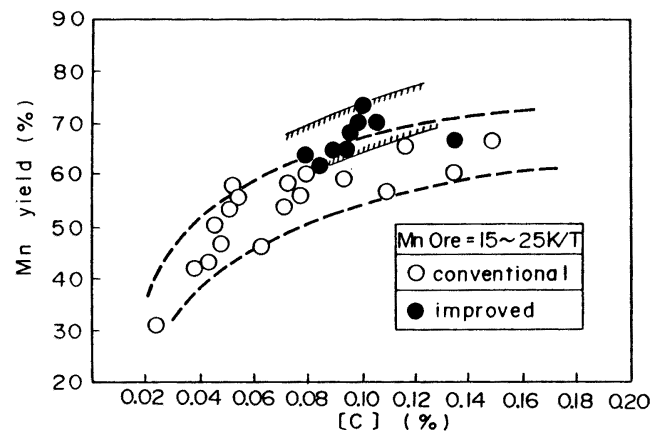

Fig. 2 Relation between [ $\mathrm{C}$ ] and $\mathrm{Mn}$ yield

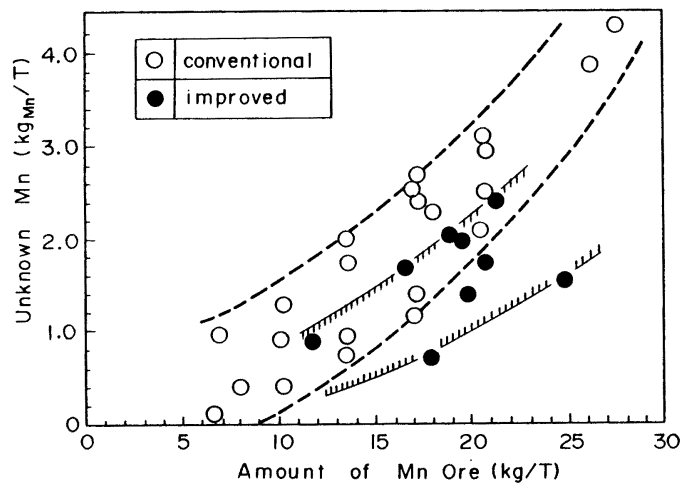

Fig. 3 Relation between input $\mathrm{Mn}$ Ore and unknown output $\mathrm{Mn}$ 


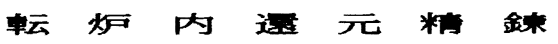

(予偖処理溶鉄吹鍊技街の開発：第6 報)

日本釷管（株）福山製鉄所
○狛谷昌紀潼千事

福味純一海老沢鬼

1. 緒言

当所に於ては、低りん溶銑を用いたレススラク吹鍊により $\mathrm{Mn}$ 鉱石の炉内添加を行ない、吹止

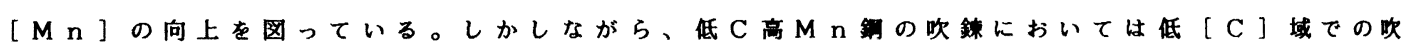
止となるため、Mn步留りは60 70\%程度にとどまっいる。このため、従来は転炉スラクを程柾

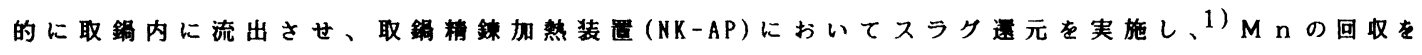
図ってきた。今回、転炬においてレススラク吹鍊㳯の遭元 試験を実施し、良好な結果が得られたので報告する。

2. 炬内遗元試駼

\section{2-1) 試験方法}

レススラク吹釟を行ない、吹止後通元用ならひにスラ ク調整用の媒溶都を妒内に投入し、底吹き強拱拌下でレ

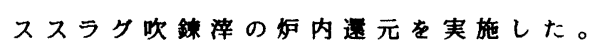

\section{2-2） Mn回収率の向上}

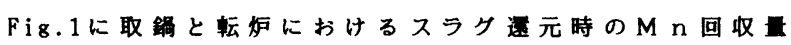
を示す。取鉿ではフリーボードの点から遭元できるスラ グに制限が有るが、伝炉ではスラクの全量透元が可能 であるためNK-APでの㸁元に比べて大巾な $\mathrm{Mn}$ 回収が可能 である。その絬果Fig.2に示すょうに全装入 Mnの約 $90 \%$ が回収できた。

\section{2-3) [P] の推移}

当試験では造元中にスラクからの復りんがあるため、 装入 [P] 極力下げる必要がある。そのため檑低りん 処理 ${ }^{2)}$ 施した溶銑を用いてレススラク吹鉡を実施する。 Fig.3に当試験におけるりんの挙動を示す。溶鉄 [ P ] か 低位に安定しているため、前吹釟からの炬内残留りんか 羊元されても、遗元後で $0.020 \%$ 程度におさまっている。 2-4)溶温度の上昇

远元都の酸化反忘熱に上り溶銅温度の上昇が見られた。 逜元都投入後 2 分で温度上昇は約 $20^{\circ}$ であった。

3. 䊀 言

取鍽に比べて大きなフリーボードと強力な港汼力をも つ転炉炬内において、レススラク吹釟摔の遭元を実施し、 高いMn回収率を得た。また热的にも大きなメリットが あることが涩められた。

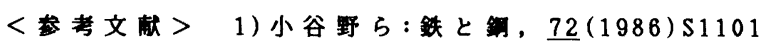

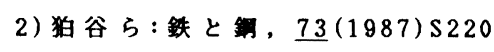

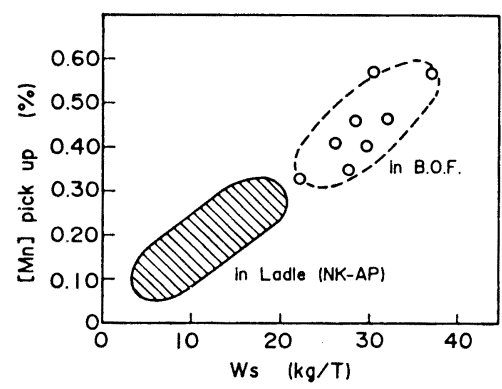

Fig. 1. Relation between slag volume and [Mn] pick up.

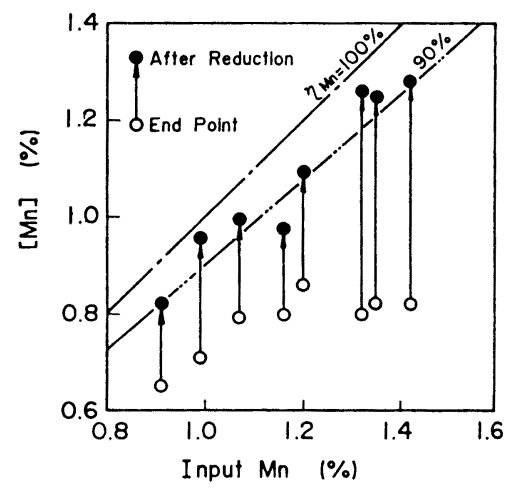

Fig.2. Changes of $[\mathrm{Mn}]$ on reduction

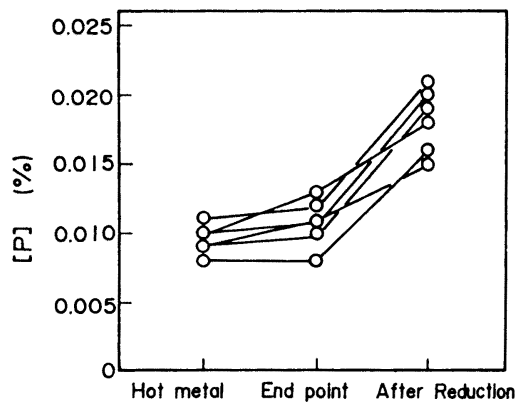

Fig.3. Changes of $[P]$. 


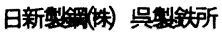

\section{1. 緒言}

転炬ダストの発生機構については、最近多くの報告がな されているが、いまだ不明な点が多い。著者らは前報 ${ }^{1} に$ おいて、上底吹転炬におけるダス卜発生挙動について調査 し、鉄ヒュームがその主体であるという推論を得た。本報 では、当所 1 製鋼上吹転炉にて調査厄実施し、上底吹転炉 での挙動との比較・検討を行なったので報告する。

\section{2. 調查方法}

$90 \mathrm{~T}$ 上吹・上底吹転炉において、O G 集塵水を採取する ととによりダストをサンプリングし、発生量お上び成分の 分析。粒径分布測定などに供した。また、一部の調査では、 Moトレーサを装入し、ダスト発生に対するバブルバー一 ス 卜比率を推定した。

\section{3. 調查結果およひ検討}

Fig. 1 亿上吹·上底吹それぞれにおけるランス高さと ダス卜発生速度との関係を示す。上吹転炉では、両者の相 関が上底吹に比べて弱く、かつ発生速度のレベルも高くな っている。

F i g. 2 にダストの粒度分布の違いを示す。てのように、 上吹では $5 \mu \mathrm{m}$ 以上の粗粒の割合が上底吹に比べて大きく、 発生機構の違いがうかがわれる。

Fi g. 3 に、上吹転炣に的 0 トレーサを添加し、(2)式に よってバブルバースト比率 $\mathrm{R}$ B を求めた結果を示す。 $\mathrm{R} \mathrm{B}$ は、吹錬中期に高くなる傾向を示しているが、そのレベル

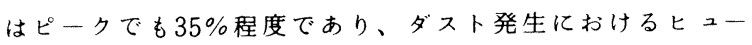
ムの寄与が大さいととが雄慧された。

$\mathrm{RB}\left[\mathrm{Mo}_{0}\right] \mathrm{B}+\mathrm{RF}[\mathrm{Mo}] \mathrm{F}=\left[\mathrm{Mo}_{0}\right] \mathrm{D}$

ここで、[Mo] $F=0 、\left[M_{0}\right] B=\left[M_{0}\right] M$ 、

$$
\mathrm{RB}_{\mathrm{B}}+\mathrm{R}_{\mathrm{F}}=1
$$

$R_{B}=\left[M_{0}\right] D /\left[M_{0}\right] M$

ただし RF：ヒューム比率、添字のB、F、D、Mは それぞれバブルバースト、ヒューム、ダスト、溶鋼を表わ す。

$$
\text { また、〔 } \left.\mathrm{Mo}_{0}\right] \mathrm{i}=\left[\% \mathrm{Mo}_{0}\right] \mathrm{i} /\left[\% \mathrm{Fe}_{\mathrm{e}}\right] \mathrm{i} \times 100 \text { である。 }
$$

\section{4. 結 言}

上吹転炉では、バブルバースド起因のダストが珰められ、上底吹転炉に比べてダスト発生量が多いひとつ の原因となっている。しかし、発生量全体に対する比率は大さなものではなく、上底吹転炬同様、ダス卜発 生の主原因はヒニームであると推定される。

参考文献：1）鉄と鋼， $73(1987)$, S 223
○平 賀 由多可 竹岡正夫山上哲也

Table 1. Blowing Conditions
\begin{tabular}{|c|c|c|}
\hline & Top Blowing & Top \& Bottom Blowing \\
\hline $\begin{array}{c}\text { Lance Height } \\
(\mathrm{mm})\end{array}$ & $1,800-2,300$ & $1,700-2,700$ \\
\hline \begin{tabular}{c}
$\mathrm{O}_{2} \begin{array}{c}\text { Blowing Rate } \\
\left(\mathrm{Nm}^{3} / \mathrm{Hr}\right)\end{array}$ \\
\hline Hot Metal
\end{tabular} & \multicolumn{2}{|c|}{16,000} \\
\hline $\begin{array}{c}\text { Slag Volume } \\
(\mathrm{kg} / \mathrm{T})\end{array}$ & \multicolumn{2}{|c|}{ Pre-Treated } \\
\hline
\end{tabular}

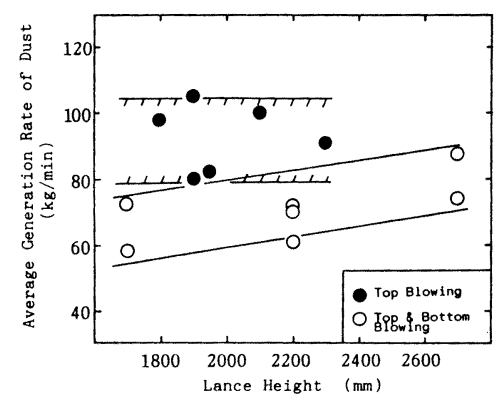

Fig.1 Relation between Lance Height and Generation Rate of Dust.

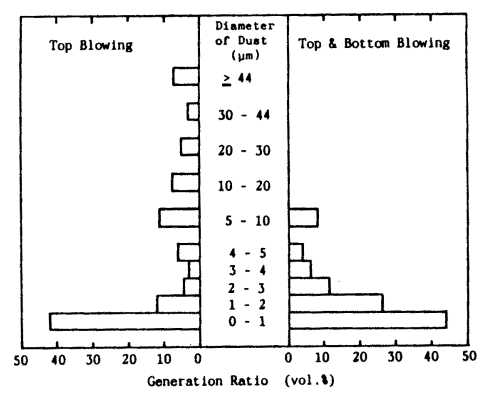

Fig.2 Distribution of Dust Particle Size.

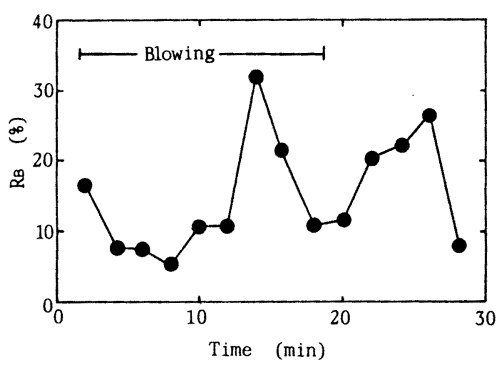
Fig. 3 Change of Bubbleburst Ratio with Time. 
被合転炉における底吹きガス広渻囲流且制御技術の開発

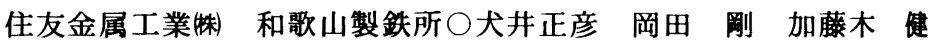
佐藤光信 森 明義

総合技術研究所 興梠昌平

\section{I . 緒 言}

Table 1. Specification of STB

当所第 2 製鋼工場 $160 \mathrm{~T}$ 上底吹き転炉（STB）において、 極低炭素鎆から高炭素鎆までの多様な溶製鋼種への対応を 図る目的で、底吹きガスの流量制御幅拡大試験を実施した。 最大底吹きガス圧力を $40 \mathrm{~kg} / \mathrm{cm}$ に設定するととにより、0.03 - $0.20 \mathrm{Nm} / \mathrm{min} \cdot \mathrm{t}$ の流量が選択でき（Tab l e 1 ), 鋼種に 応じた最適な吹鍊を行うことが可能となった。

\section{II試験結果}

\begin{tabular}{|c|c|c|}
\hline \multicolumn{2}{|l|}{ Capacity } & $160 t$ \\
\hline \multicolumn{2}{|l|}{ Tuyere } & Multi-hole nozzle \\
\hline \multicolumn{2}{|c|}{ Number of tuyeres } & 2 \\
\hline \multirow{3}{*}{$\begin{array}{l}\text { Bot tom } \\
\text { bl owing }\end{array}$} & Gas & $\mathrm{Ar}, \mathrm{N}_{2}$ \\
\hline & Rate & $0.03-0.20 \mathrm{Nm} / \mathrm{m} \cdot \mathrm{t}$ \\
\hline & Pressure & Ma x. $40 \mathrm{~kg} / \mathrm{ct}$ \\
\hline
\end{tabular}

1. 底吹き精鍊パターン

従来パターンの他， 3 種のガスパターンについて試験を 実施した。（Fig．1）。いずれも吹錬末期に底吹きガス量 を増大させ、脱炭の進行及びスラグーメタル反応の促進を 狙った。

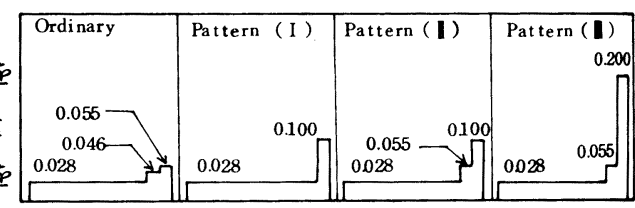

2. 低炭素鋼への適用 (パターン I, I：非脱 $\mathrm{P}$ 銑使用) 吹鍊末期のみの底吹流量增によっても、低炭域（［C] $\leqq 0.04 \%$ )でのスラグ中（T.Fe）は充分に低減される(Fig. 2 )。更にパターン I では、従来の脱炭速度低下遷移 C 濃度 ( $[\mathrm{C}] \fallingdotseq 0.50 \%)$ 近傍より次第に底吹き流量を上げ溶鋼擳拌 力を維持させた結果、低炭域での（T. F e ）のばらつきは極 めて小さくなった。

炣内脱 $\mathrm{P}$ 能は従来パターンに較べ低下している（Fｉｇ．３） が、掻化率には有意差はないのでスラグーメタル反応も考 虑した底吹き筧拌技術の選択が重要と考えられる。

3. マンガン鉱石の還元（パターン I，四：脱 $\mathrm{P}$ 銑使用）

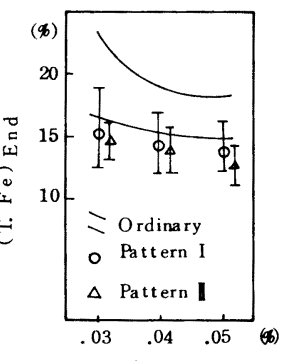

(C)End

F i g. 2 Ef fect of blowing pattern on (T. Fe) at blow end

底吹きガスの増加に伴いマンガン歩留は上昇し（Fig. 4), パターンでは 低炭域でも（T， F e ）<10\%に制御可能なため、マンガン鉱石投入時期およ び方法、スラグコントロール方法の改善とあわせて、高いマンガン歩留を 得た。

\section{4. その他}

底吹き羽口の溶損については、従来法と大差なかった。

\section{II. 結言}

複合吹鍊における底吹きガス流量の広範囲な制御試験を実施した結果 鋼種に対応した最適な精鍊が可能となった。

\section{[参考文献]}

1 ) G. W. He a l y : J IS I, $208(1970), 664$

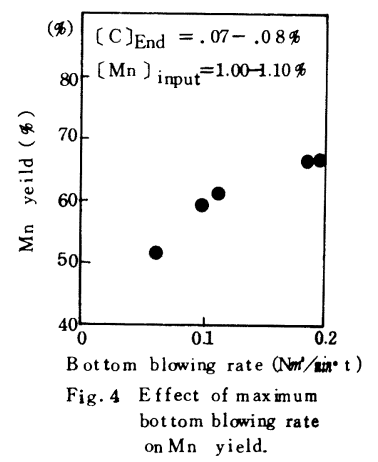




\section{(281) 上底吹転炬に扮ひる希釈脱宸法の改善}

川崎製鉄水島製鉄所 ○小山内寿 三崎規生 武 英雄 山根 明 今井卓雄

\section{1. 緒言}

純酸素上底吹転炉において，脱炭効率の低下する低炭素域て底吹酸素ガスの一部を不活性ガスに置き換える，いわ ゆる不活性ガス布釈脱炭法（IOD 法）が脱炭効率向上に乵果があることは以前に示した。1) 本報では，最適なIOD バターン制御を新しいダイナミック制御システムとの組み合わせにより行い，効果を上げることができたので報告す る。

2. I ODバターンの改善

上底吹転炉において擅拌に寄与する底吹ガス量 $Q_{\mathrm{B}}$ は(1) 式で表わされる。

$$
\begin{aligned}
& \mathrm{Q}_{\mathrm{B}}=2 \times \eta_{\mathrm{c}} \times \mathrm{Q}_{02}+\mathrm{Q}_{\mathrm{I}} \quad \cdots \text { (1) } \\
& \left\{\begin{array}{l}
\eta_{\mathrm{c}}: \text { 脱炭酸素効率 } \\
\mathrm{Q}_{02}: \text { 底吹酸素ガス量 } \\
\mathrm{Q}_{1}: \text { 底吹不活性ガス量 }
\end{array}\right.
\end{aligned}
$$

Fig.1 (a)が従来のIOD バターンである。低炭素域で $\eta_{\mathrm{c}}$ $<0.5$ となったとき, 不活性ガスを吹込むことにより(1)式 で示される全底吹ガス量 $\mathrm{Q}_{\mathrm{B}}$ は增加し，P coの希釈効果も 加わって撜拌を增大させている。この時 $\eta \mathrm{c}$ が小さくて不 活性ガス添加効果の大きい低炭域でさらに不活性ガスを增 し，一方， $\eta_{\mathrm{c}} \simeq 0.5$ で不活性ガス添加勃果の小さい炭素 域で不活性ガス量を小さくする（Fig.1 (b)）。これによっ て、同一ガスコストて ( T. Fe) 低減等の効果がより大きく なる。

\section{3.ダイナミック制御}

IOD 法における脱炭の制御は，転炉の操業管理全般をつ かさどる新プロセスコンビューター゙によって自動的に行 われる。Fig.2において，サブランス投入時点の炭素浱度 の測定値から，脱炭曲線y，式を積分してIOD 開始酸素量 を求め，吹止までの遂一の酸素ガス・不活性ガス流量も計 算されて，まとめてDDC へ伝送される。こうして，鋼種別 にあらかじめ定められたバターンでIOD 処理がなされる。

\section{I O Dバターン改善の効果}

新しいIOD パターンの効果は，摫䢁力・脱炭勃率の上昇 による吹止O，吹止（T.Fe）の低減，および，P分配比の 向上である。Fig.3 に，吹止Cと吹止O関係を示す。吹 止互か低い領域において特に兰低減の勃果が大きい。 <参考文献>
1）大西ら ; 鉄と鋼， 69 (1983)12, \$1015
2 ）本大会発表予定

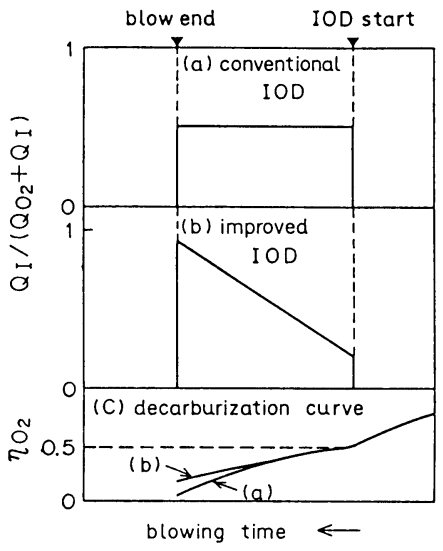

Fig.1 Improvement of IOD pattern

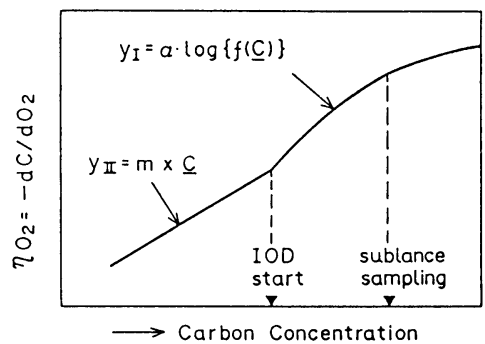

Fig.2 Automatic IOD starting using dynamic control system

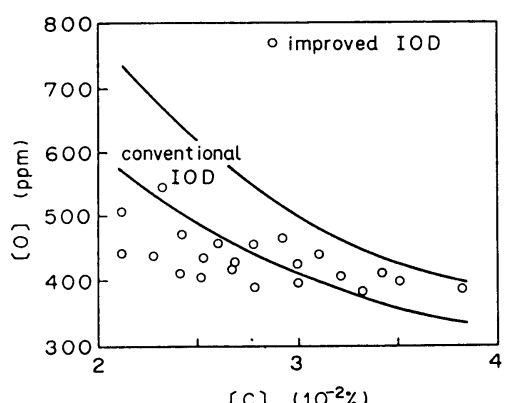

Fig. 3 Relation between (O) and (C) at blow end 


\section{1. 緒 言}

少量スラグでの転炉吹錬時，ダスト発生の抑制・スラグの過酸化防止のための上吹を条件の最適化が 重要な課題となる。そとで上吹を酸素噴流の運動エネルギーと鋼浴キャビティ形状から，浴のスピッテ ィング・攪拌状態を推定するモデルを作成した。更に水モデル実験, および実炬でモデルの妥当性を検 討した。その結果，最適な上吹さ条件の採用に上り実機吹鍊で転炬ダスト発生量の低減およびスラグ $\mathrm{T} \cdot \mathrm{Fe}$ 低減が同時に可能となるのを確認したので報告する。

2. スピッティング・㩑拌モデル

（仮定条件）

i) 底吹さェネギー $\dot{\varepsilon}_{\mathrm{B}}$ はすべて攪拌に消費される。

ii) 上吹をエネルギー郎のらち一部はスピッティング発生に用いられ, その比率 $\alpha$ はキャビティ形状 $(\mathrm{L} / \mathrm{D})^{\mathrm{n}}$ 飞比例する。

iii) $\dot{\varepsilon}_{\mathrm{T}}$ のち一部は鋼浴の㩭拌に用いられ, その比率 $\beta$ も $(\mathrm{L} / \mathrm{D})^{\mathrm{m}} \mathrm{K}$ 比 例する。

(モデル概要 )

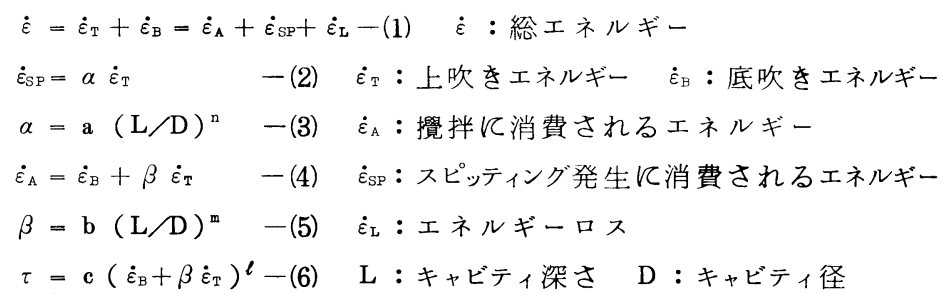

3. 水モデル実験への本モデルの適用

本モデルを水モデル実験結果に適用するとFig.1 および 2 亿示すよ らに $\alpha, \beta$ とも $\mathrm{L} / \mathrm{D} て ゙$ 整理でき，スピッティング量と浴撜拌は上吹き条 件の $\dot{\varepsilon}_{\mathrm{T}}$ と $\mathrm{D}$ 両者の影響を受ける。

\section{4. 転炉操業での本モデルの検証}

ダスト発生機構をスピッティング粒の脱炭反応によるバースト粒と

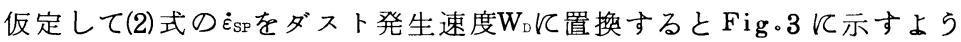

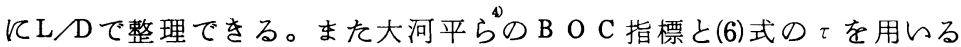
とFig.4亿示すように $\beta$ はL Dで整理できる。すなわちダスト発生を 抑制するには帛を小さくし，かつL/Dを大をくする。を(4)式の関係 から完を上げるためにも L/Dを大をくする上吹き条件が好ましい。

\section{5. 結 言}

本モデルの妥当性を水モデルおよび実炬で確認し, 上吹き条件の最 適化によりダスト発生量・スラグT·Feの低減可能なととが確認できた。

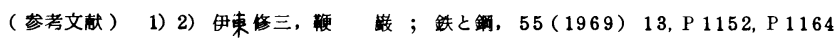

3）中村康久, 山本里見, 阿部泰久 ; 新日鐵社内技報（私信）1982 年 3 月

4) 大河平和男, 平居正純, 村上晶三, 甲斐幹; 制究 314 号 (1984)

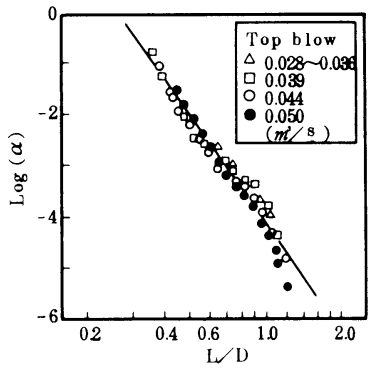

Fig. 1. Relation between $\mathrm{L}, \mathrm{D}$ and $\alpha$ wat er model test)

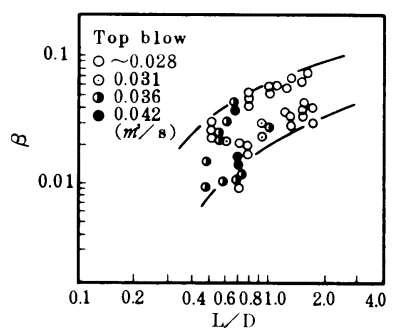

Fig.2. Rela tion between $\mathrm{L} / \mathrm{D}$ and $\beta$ (water model test)

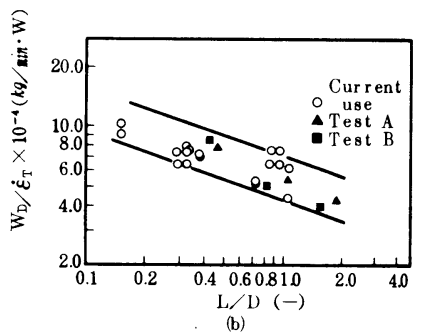

Fig. 3. Relation between $L / D$ and $W_{D} / \varepsilon_{\text {T }}$ (actual operation)

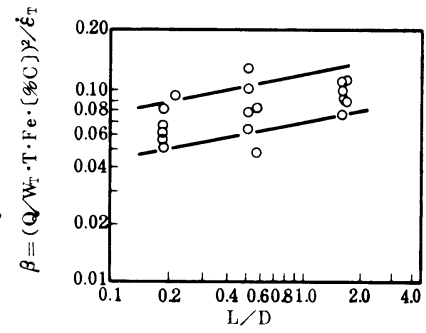

Fig.4. Relation bet ween $\mathrm{L} / \mathrm{D}$ and $\beta$ (actual operation) 
1.緒言 金展の精銤遇程で使用されるフラックスの塩基度として塩基性酸化物と酸性酸化物の組成比が 用いられているが、これが塩基度を定量的に表しているとは言い難く、また強塩基性フラックスやハロ

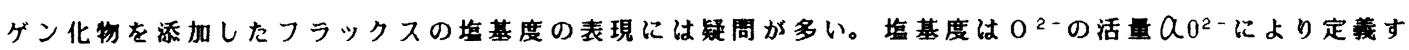
るのが最も望ましいが、これを直接测定することは原理的にできない。本研究ではフラックス中での銅

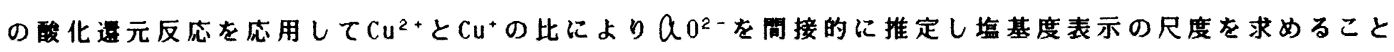
を目的とした。

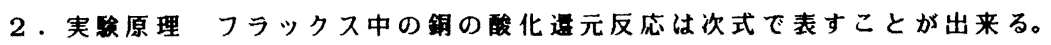

$$
\mathrm{Cu}^{+}+\frac{1}{4} 0_{2}=\mathrm{Cu}^{2}+\frac{1}{2} 0^{2-}
$$

フラックス中の制イオンの存在比は

$$
\log \frac{\left(\% \mathrm{Cu}^{2+}\right)}{\left(\% \mathrm{Cu}^{+}\right)}=-\frac{1}{2} \log Q_{0^{2}}+\frac{1}{4} \log \mathrm{Po}_{2}+\log \frac{\left(\mathrm{fCu}^{+}\right)}{\left(\mathrm{fCu}^{2+}\right)}+\log \mathrm{K}
$$

と表せる。一定の温度、 $\mathrm{Po}_{2}$ で組成により鍮イオンの活量 係数の比が变化しなければ $\mathrm{Cu}^{2+} / \mathrm{Cu}^{+}$と $\mathrm{O} \mathrm{o}^{2-の}$ 関係が得ら れる。本研究では $\mathrm{Na}_{2} \mathrm{O}-\mathrm{Si} 0_{2} 、 \mathrm{Na}_{2} \mathrm{O}-\mathrm{NaF}-\mathrm{Si} 0_{2} 、 \mathrm{CaO}-\mathrm{Na}_{2} \mathrm{O}-$ $\mathrm{SiO}_{2}$ 系フラックスの $\mathrm{Cu}^{2+} / \mathrm{Cu}^{+}$の組成依存性を融べた。 $\mathrm{Na}_{2} \mathrm{O}-\mathrm{Si} 0_{2}$ 系では一定組成での温度依存性も調べた。

3.実駼方法目的組成に混合した試菜にCu0を加えた試料 $4 \mathrm{~g}(\mathrm{Cu}=2 \%)$ を白金るつぼ入れ、所定の温度（1100-1400 ${ }^{\circ}$ C ) 2 時間保持し空気囲気下で溶融平衡させた。実験 後武料を急冷し組成分析を行った。

4. 結果と考察 Fig.1 1 示すようにNa2 $0-\mathrm{SiO}_{2}$ 系フラック スの $\mathrm{Na}_{2} \mathrm{O} / \mathrm{Si} 0_{2}$ の增加に伴い $\mathrm{Cu}^{2+} / \mathrm{Cu}^{+}$は娍少した。これによ り $\mathrm{Cu}^{2+} / \mathrm{Cu}^{+}$が $\mathrm{QO}^{2}{ }^{2-k}$ 依存することがわかる。 $\mathrm{Na}_{2} \mathrm{O}-\mathrm{NaF}$ $\mathrm{SiO}_{2}$ 系でも同㥞に $\mathrm{Na}_{2} \mathrm{O} / \mathrm{SiO} \mathrm{O}_{2}$ の增加に伴い $\mathrm{Cu}^{2+} / \mathrm{Cu}^{+}$は娍少し た。NaFを含む系では、 $\mathrm{Na}_{2} \mathrm{O}-\mathrm{Si} 0_{2}$ 系に比べ僅かに高い $\mathrm{Cu}^{2+} / \mathrm{Cu}^{+}$を示し、NaFによる希积效果が認められる。Fig.2 に $\mathrm{Ca}_{0} 0-\mathrm{Na}_{2} \mathrm{O}-\mathrm{Si} 0_{2}$ 系フラックスの結果を示す。 $\left(\mathrm{Ca} 0+\mathrm{Na}_{2} \mathrm{O}\right) /$ $\mathrm{Si} 0_{2}=1$ (wt\%/wt\%) とし CaOを $\mathrm{Na}_{2} 0$ で置换すると $\mathrm{Na}_{2} 0$ の增加に 伴い $\mathrm{Cu}^{2+} / \mathrm{Cu}^{+}$は娍少した。これは $\mathrm{Na}_{2} \mathrm{O}$ が $\mathrm{Ca} 0$ より㙁基性であ

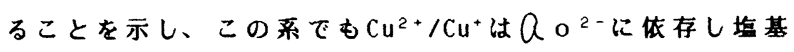
度の尺度となり得る。また温度依存性の実稌から $\Delta H^{\circ}=$ $15.1 \mathrm{~kJ} /$ mol と求められた。この值は S.Banerjeeら 'が $30 \mathrm{Na}_{2} 0-70 \mathrm{~B}_{2} \mathrm{O}_{3}$ 系ガラスで求めた $61.0 \mathrm{KJ} / \mathrm{molk}$ の値となっている。

文献 1)S.Banerjee：J.Am.Ceram.Soc,57(1974),p.286 


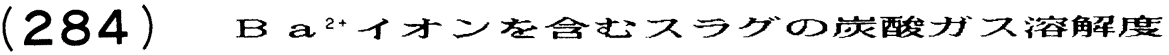

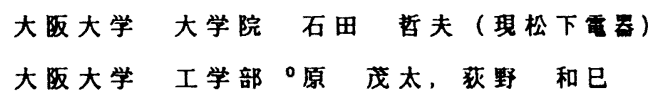

1. 目的

近年、溶銑予借处理用のフラックスとして、精練作用の後れた強塩基性のスラグの使用が指向され ており、特に、強塩基成分として $\mathrm{BaO}$ を含むスラグが注目されている。前報においては、BaO- $\mathrm{BaCO}$

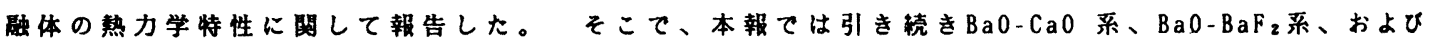
$(\mathrm{Ca}, \mathrm{Ba}) 0-(\mathrm{Ca}, \mathrm{Ba}) \mathrm{F}_{2}$ 系について $\mathrm{CO}_{2}$ の溶解度の测定からこれらの系の熟力学特性について即した。

\section{2. 実筑方法}

実煖は、 $\mathrm{BaCO}_{3}, \mathrm{CaCO}_{3}, \mathrm{BaF}_{2}$ ，および $\mathrm{CaF}_{2}$ 等の混合塩を出発物算として、温度と $\mathrm{CO}_{2}$ 分王を规定し

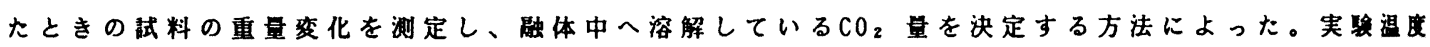

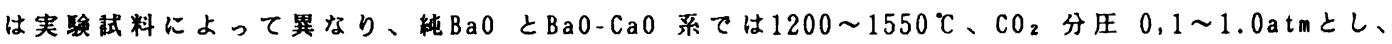

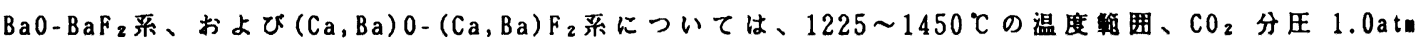
について测定を実施した。

\section{3. 結果}

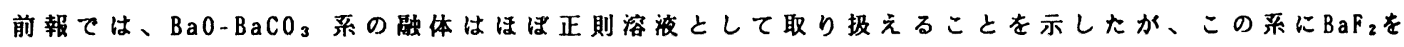

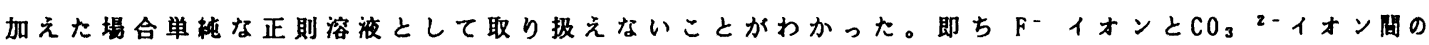
相互作用は組成の関数として变化する。図1にはこの

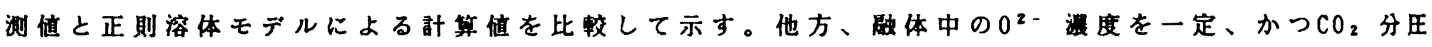
を $1.0 \mathrm{~atm} と し 、 \mathrm{Ba}^{2+}$ イオンの一部を $\mathrm{Ca}^{2+}$ イオンによって檤き换えた埸合、 $\mathrm{CO}_{2}$ の溶解度はカ子オン 比, $\mathrm{N} \mathrm{Ba}^{2+} /\left(\mathrm{N} \mathrm{Ba}^{2+}+\mathrm{N} \mathrm{Ca}^{2+}\right)=0.4$ を境として急湤に增加し（図2）、またこの近㥬の組成て溶瞵 度の温度依存性が急湤に变化することかわかった。

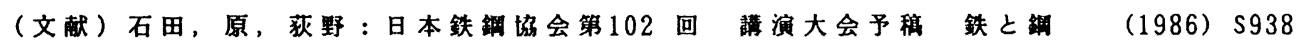

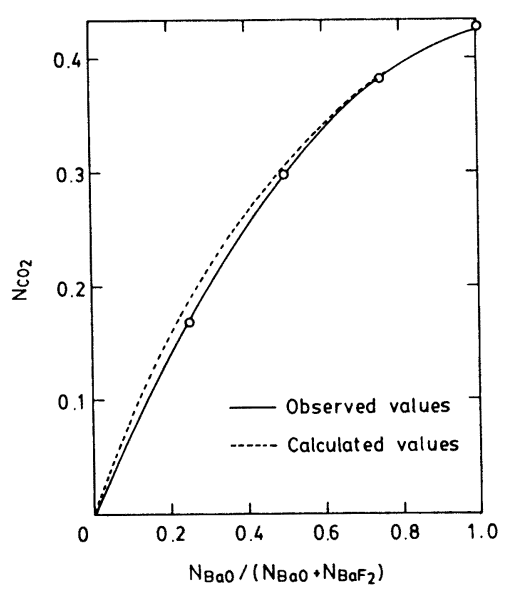

Fig. 1 Solubilities of $\mathrm{CO}_{2}$ in $\mathrm{BaO}-\mathrm{BaF}_{2}$ Melts at $1400^{\circ} \mathrm{C}\left(\mathrm{PCO}_{2}=1 \mathrm{~atm}\right)$

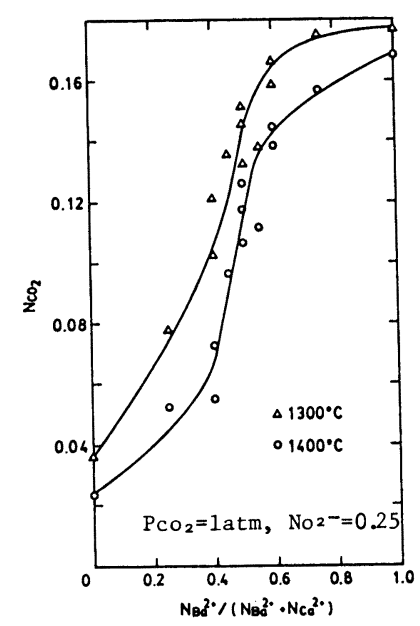

Fig. 2 Effect of Cation Ratio on the $\mathrm{CO}_{2}$ Solubility in $(\mathrm{Ca}, \mathrm{Ba}) \mathrm{O}-(\mathrm{Ca}, \mathrm{Ba}) \mathrm{F}_{2}$ Melts 


$\begin{array}{lr}\text { 東京大学大学院 } & \text { O若杉 隆 } \\ \text { 東京大学工学部 } & \text { 佐野信雄 }\end{array}$

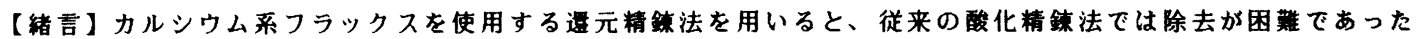
IV b、V b族の元素を、有用金属の酸化損失なしに除去できる。すでに熱力学的データを测定したP,Sb,Snに引き続 き12)、本研究では、 $\mathrm{Ca} 0-\mathrm{CaF}_{2}$ 系フラックス中でのAs、Pb、Biの熱力学的举動を、酸素分压、組成、温度をバラ メータとして調べた。

【実臥方法】グラファイトるつぼ内に、メタルとしてAg-1\%As 合金 $(2 g)$ または金属鉛 $(15 g)$ または $\mathrm{Ag}-10 \% \mathrm{Bi}$ 合金 $(2 \mathrm{~g}) 、$ 、スグ として CaO- $\mathrm{CaF}_{2}$ 系スラグ $(4 \sim 10 \mathrm{~g})$ を入れ、温度を一定に制御し たSiC電気抵抗炉内に設置し、一定混合比のAr-C Oガスと平衡 させた。実臥は主に $1500^{\circ} \mathrm{C}$ で行い、温度依存性の実駼は1370 $1550^{\circ} \mathrm{C}$ の轮囲で行った。

【実駼結果及び考察】本研究で用いたスラグ系において不純物 Mの除去反応は (1)式で表現できる。従って(1)式から、分配比は

(2)式で表される。

$$
\begin{aligned}
M+x \mathrm{Ca}_{0}= & \mathrm{Ca} a_{x} M+x / 20_{2} \cdots(1) \\
\log L_{M}= & x \log a_{C_{a} 0}-x / 2 \log P_{O_{2}}+\log K_{1} \\
& -\log f / f \cdot-\log \left(W_{C_{x} M} / W_{M}\right) \cdots(2)
\end{aligned}
$$

( $f:$ :スグ中 $\mathrm{C} a \times$ Mの活量係数, $\mathrm{f}^{\prime}:$ メタル中Mの活量係数,

Wi：成分の分子量)

ただし、Pbの場合はメタルとして金属鉛を用いているために分

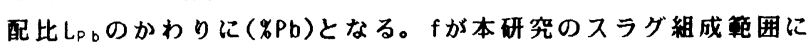
おいてほぼ一定とすると右辺第四項は定数とみなすことができ るので、

$$
X=\left(\frac{\partial \log L_{M}}{\partial \log a_{c_{0} 0}}\right)_{P_{o_{2}, T}}=-2\left(\frac{\partial \log L_{M}}{\partial \log P_{0_{2}}}\right)_{a_{c_{0} 0, T}} \cdots(3)
$$

により、（2）式の係数Xが定まる。選元条件下でのAs、Biの最も 安定な価数はー3、Pbはー4であることから、Xはそれぞれ1.5、 2と予溂される。

$1500^{\circ} \mathrm{C} 、 \mathrm{Ca} 0$ 铇和組成におけるAs, Bi , Pbの酸素分圧依存性を、 Fig.1に示す。Fig.1の右下がりの直線の傾きはそれぞれー0.63、 -0.80、ー1.16であり、理論值（As,Biについては一0.75、Pbに ついては一-1）とよく一致する。また、As及びPbの組成依存性の グラフ（省略）より、理論植1.5、2.0に対してそれぞれ1.6、

2.20傾きが得られた。これよりスラグ中でAs，Bi，Pbはそれぞれ、 $\mathrm{As}^{3-} 、 \mathrm{Bi}^{3-} 、 \mathrm{~Pb}^{4-と し て}$ 存在することがわかる。また $\mathrm{Pb} \mathrm{Po}_{2}=$ $10^{-16} \sim 10^{-19} \mathrm{~atm}$ の釷囲で直線の傎きが0であることから、この 酸素分压箅囲においてP防みかけ上金属としてスラグ中に溶解 していることがわかる。

As及びPbの温度依存性をFig.2に示す。温度が高くなるにつれ $\tau L_{A S}$ ，(\%Pb)加增加する。直線の䫅きか反応生成物 $\mathrm{Ca}_{3} \mathrm{As}_{2}$ 及び $\mathrm{Ca}_{2} \mathrm{~Pb}$ のララグへの涴解愁を含む標準生成エンタルビー变化は、 それぞれー741kJ/mol, - 447kJ/molと求められた。

参考文献：1)S.Tabuchi et al:Metall.Trans., 15B(1984)p.351 2) T.Isawa et al:Steel Research,58(1987) No?

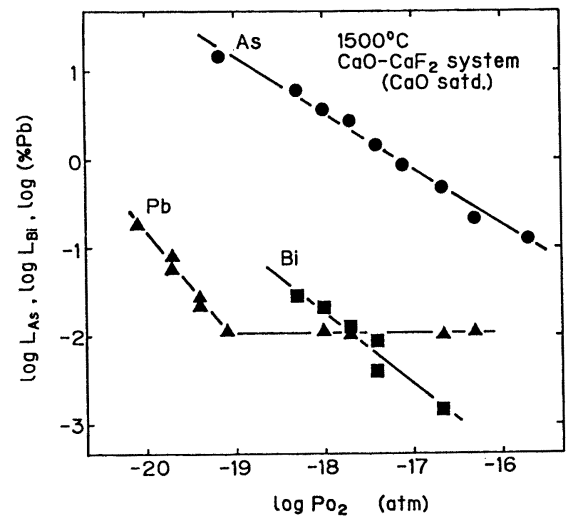

Fig.1 Dependence of $\mathrm{As}$ and $\mathrm{Bi}$ distribution between $\mathrm{Ag}$ and $\mathrm{CaO}-\mathrm{CaF}_{2}$ melts and $\mathrm{Pb}$ content in $\mathrm{CaO}-\mathrm{CaF}_{2}$ melts on oxygen partial pressure.

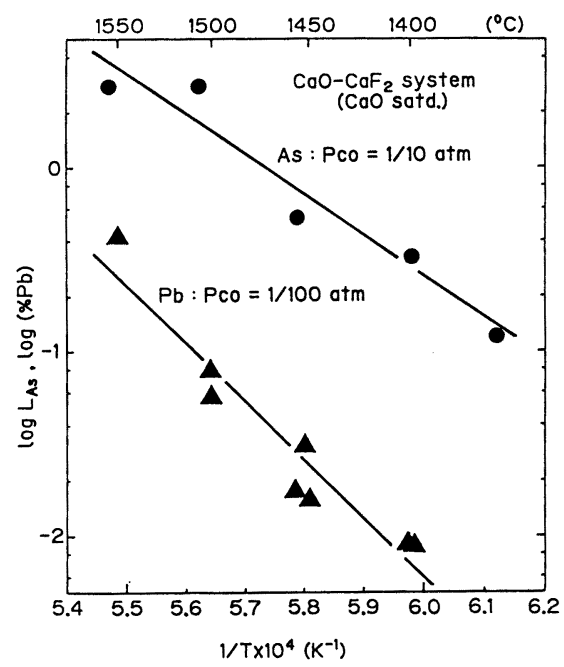

Fig. 2 Dependence of As distribution between $\mathrm{Ag}$ and $\mathrm{CaO}-\mathrm{CaF}_{2}$ melts and $\mathrm{Pb}$ content in $\mathrm{CaO}-\mathrm{CaF}_{2}$ melts on temperature. 
（286） $\quad \mathrm{Na}_{2} 0$ 添加 $\mathrm{Ca} 0-\mathrm{CaF}_{2}-\mathrm{SiO}_{2}$ 系フラックスー炭素飽和楁鉄閧の バナジウム、ニオブ、マンガンの分配

東京大学工学部 ○月橋文孝、田谷あつ子、佐野信雄

1. 绪言 著者の一人は、現在楁鉄予借处理に用いられているCa0-CaF $-\mathrm{SiO}_{2}$ 系フラックスのうち最大の帨りん能 を持つ、 $\mathrm{Ca} 0 、 3 \mathrm{Ca} 0 \cdot \mathrm{SiO}_{2}$ 両飽和 $\mathrm{Ca} 0-\mathrm{CaF}_{2}-\mathrm{Si}_{2}$ 系フラックスに、少量の $\mathrm{Na}_{2} 0$ を添加することにより、帨りん能加向上 することを見いだした ${ }^{1 \prime}$ 。本研究では、このフラックスを脱りん処理に用いた時のバナジウム、ニオブ、マンガン の举動を調べるために、 $\mathrm{Na}_{2} \mathrm{O}$ 添加 $\mathrm{Ca} 0-\mathrm{CaF}_{2}-\mathrm{Si} 0_{2}$ 融体中のこれらの元素の熟力学的性筫を調べた。

2. 実医方法黑鉛坩倜に所定組成のフラックス $(3 g)$ と炭素飽和溶鉄（2g）とナトリウムボテンシャルを保っ

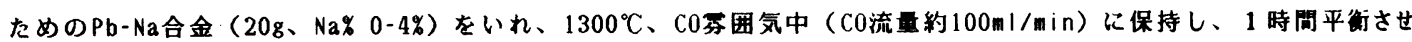

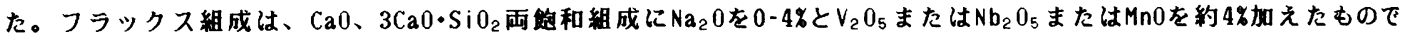
ある。炭素铇和溶鉄中にもバナジウムまたは二オブまたはマンガンを加え、これらの元素が、フラックスから炭素 飽和溶鉄へ移動する方向と、その逆方向の実験を行い平衡到達を確認した。ニオブとバナジウムは、フラックス中 に種々の価数で存在するので、価数別の定量も行った。

3. 結果 $\quad \mathrm{Fig} .1 \mathrm{KCa} 0-\mathrm{CaF}_{2}-\mathrm{Si}_{2}$ 系フラックスー炭素 飽和楁鉄䦓のバナジウム、ニオブ、マンガンの分配比に対す る添加 $\mathrm{Na}_{2} 0$ 量の影整を示す。 $\mathrm{Na}_{2} 0$ 量が增加するに従いバナジ ウム、ニオブの分配比は增加し、約 $2 \% の \mathrm{Na}_{2} 0$ 添加で分配比 は約 1 栴大きくなる。一方、 $\mathrm{Na}_{2} 0$ の添加と共にマンガンの分 配比は娍少する。これはSimeonov らが判定した、Ca0系フ ラックスへの $\mathrm{Na}_{2} 0$ 添加のマンガン分眍比におよぼす影䇾と同 じ傾向を示している。鉛中ナトリウム量により計算される $\mathrm{Na}_{2} 0$ の活量から、同じ $\mathrm{Na}_{2} 0$ の活量を持つ $\mathrm{Na}_{2} 0$ 添加 $\mathrm{Ca} 0-\mathrm{CaF}_{2}$ $\mathrm{SiO}_{2}$ 系フラックスと $\mathrm{Na}_{2} \mathrm{O}-\mathrm{SiO}_{2}$ 系フラックスのバナジウムの

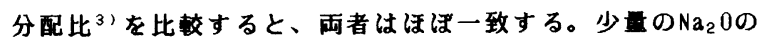
添加で、 $\mathrm{Ca} 0-\mathrm{CaF}_{2}-\mathrm{SiO}_{2}$ 系フラックスのV精銤能が $\mathrm{Na}_{2} 0-\mathrm{Si}_{2}$ 系フラックスに匹敵するといえる。一方、Nbについては、本 系の分配比は $\mathrm{Na}_{2} \mathrm{O}-\mathrm{SiO}_{2}$ 系のそれに比べて 1 妳小さい。Fig. 2 にフラックス中のバナジウム、ニオブの価数の $\mathrm{Na}_{2} 0$ 添加量 による影慗を示す。ニオブは主に 5 洒で存在するが、バナジ ウムの原子洒は主として4 価で、5洒も混在する。

4. 結票 $\mathrm{Ca} 0-\mathrm{CaF}_{2}-\mathrm{SiO}_{2}$ 系フラックスに少量の $\mathrm{Na}_{2} 0$ 添 加することにより、脱りん能の向上を図るとともに、ニオブ、 バナジウムをスラグに除去し、マンガンの楁銑中歩留りを上 げることができる。

文献：1）村木ら：鉄と鎮、71(1986)、p.693.

2) Simeonovら: Trans.|S।J,25(1985)、p.1116.

3）月橋ら：鉄と鍊、71(1986)、p.823.

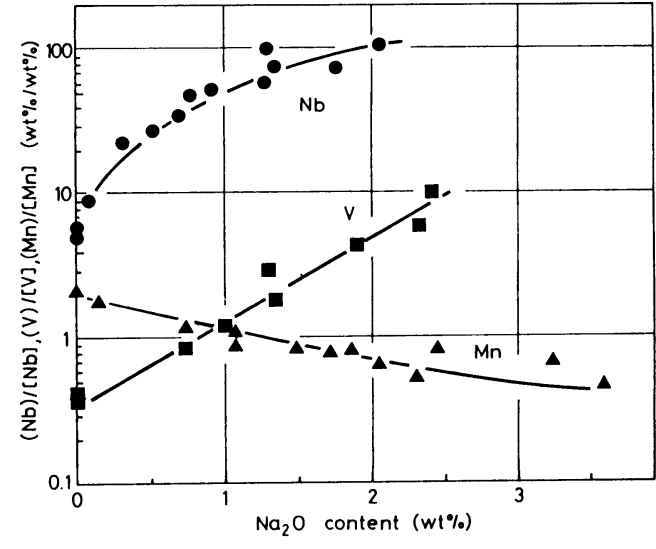

Fig.1. Partition of vanadium, niobium and manganese for the $\mathrm{Na}_{2} \mathrm{O}-\mathrm{CaO}-\mathrm{CaF}_{2}-\mathrm{SiO}_{2}$ system saturated with $\mathrm{CaO}$ and $3 \mathrm{CaO} \cdot \mathrm{SiO}_{2}$ at $1300^{\circ} \mathrm{C}$.

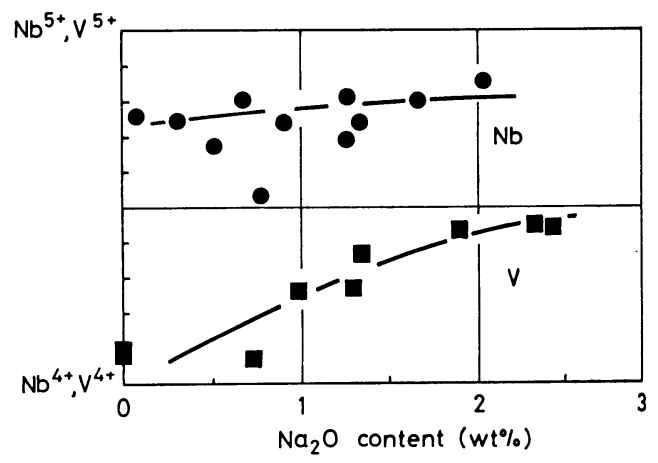

Fig.2. Change in valency of vanadium and niobium with addition of $\mathrm{Na}_{2} \mathrm{O}$ to the $\mathrm{Na}_{2} \mathrm{O}-\mathrm{CaO}-$ $\mathrm{CaF}_{2}-\mathrm{SiO}_{2}$ system saturated with $\mathrm{CaO}$ and $3 \mathrm{CaO}$. $\mathrm{SiO}_{2}$ at $1300^{\circ} \mathrm{C}$. 


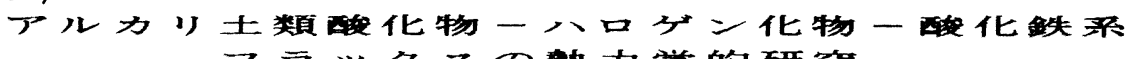
フラックスの想力等的研究

京都大学工学部 0 姜茂発、一濑英再、岩濑正則

\section{【1. 粕言】}

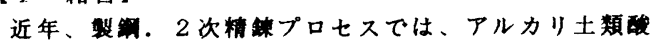
化物一塭化物系のフラックスが使用されているが、これ らのフラックスの䑨力学的性黄はほとんど不明である。 著者らは、これまで、これらのフラックス中の酸化铁の 活量を測定してきた。测定対象はMO+ $\mathrm{MCl}_{2}+\mathrm{FeO}$ 系（以

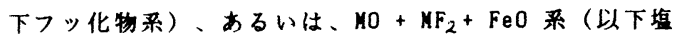
化物系）（ただし、M $=\mathrm{Ca}, \mathrm{Sr}, \mathrm{Ba} ） 、$ 合計 6 つの 3 元 录フラックスである。これらの测定䊅果の一部は、すで に報告した/1/。本報では、これらの結果をまとめて報 告し、アルカリ土類酸物ーハロダン化物一化制系フ ラックスに共通した䑡力学的性筫について考察する。

\section{【2実脸方法】}

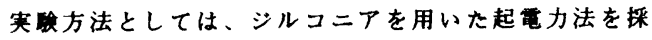

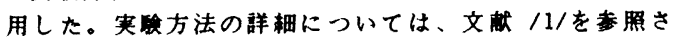
れたい。なお、この实馀方法は著者らが考案したもので あるが、Chavez/2/,Dippenaar/3/らは、著者らがすでに 測定したスラグ系について追実唤を行なったところ、き わめて良好な一票が得られた事を報告している。

\section{【3実結果】}

3.1活年の組成依在性; 㙁化物系、フッ化物系を闾わ す、化物／ハロダン化比が大きくなるに朕って酸化鉄 の活量は低下した。また、Fig.1に示すように、酸化物 ノハロダン化物比が同じ场合には、Ca系, Sr系, Ba系の 頜に活量は低下する。

3.23 元系状態図; 活量测定結果をもとにして得られ た等温断面図を図2に示すが、均一液相領城は、Ca系、 $\mathrm{Sr}$ 系、Ba系の貝に広くなる。

$3.3 \mathrm{Fe}^{2+} / \mathrm{Fe}^{3+}$ 平解;
$2 \mathrm{Fe}^{2+}+(1 / 2) \mathrm{O}_{2}(\mathrm{~g})=2 \mathrm{Fe}^{3+}+0^{2-}$ と表わされるが、ここでFe $\mathrm{F}^{2+}$ イオンと $\mathrm{Fe}^{3+}$ イオンの活 量係数の比は、スラグ組成によらず一定と仮定すると、 $\log \mathrm{a}_{\mathrm{O}^{2-}}=(1 / 2) \log \mathrm{P}_{2}+2 \log \left[\left(\mathrm{Fe}^{2+}\right) /\left(\mathrm{Fe}^{3+}\right)\right]$ $+\log K$ となる。この式の右辺第二項までの值と $\mathrm{Fe} 0$ モル分事との䦕係を図3に示した。フッ化物系では、 この值は $\mathrm{X}_{\mathrm{FeO}} \mathrm{O}$ のの関数であり、MO/MF 一方塭化物系では、MO/MCl2 比によって变化した。

3.4 活量の沮度依在性; すへての系について次式によ って活量の温度依存性を表わしうることがわかった。

$$
\mathrm{R} T \text { In } \gamma_{\mathrm{FeO}}=\text { 一定 }
$$

\section{【文献】}

11/ $\mathrm{CaO}-\mathrm{CaCl}_{2}-\mathrm{FeO}$ 系: Trans ISS/AIME, 4(1984), 53, $\mathrm{CaO}-\mathrm{CaF}_{2}-\mathrm{FeO}$ 系: ibid,4(1984)69, $\mathrm{BaO}^{-\mathrm{BaCl}_{2}}$ -Fe0系: ibid, 8(1986)37.,

/2/ F. Chavez et al.: Trans. JIM, 26(1985), 825.

/3/ Dippenaar et al.;J.S.Afr. Inst. Min. Met., $86(1986), P .443$

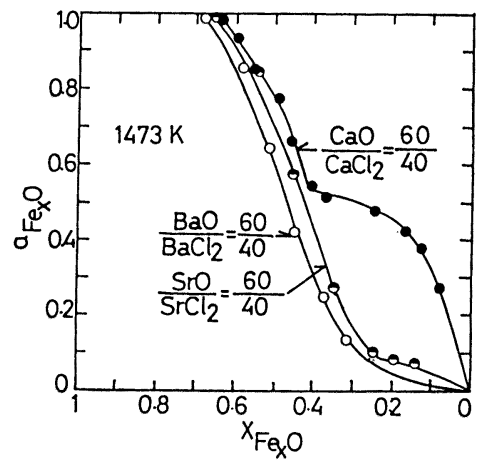

Fig. 1 Activities of $\mathrm{FeO}$ in $\mathrm{MO}+\mathrm{MCl}_{2}+\mathrm{FeO}$ fluxes at $1473 \mathrm{~K}$
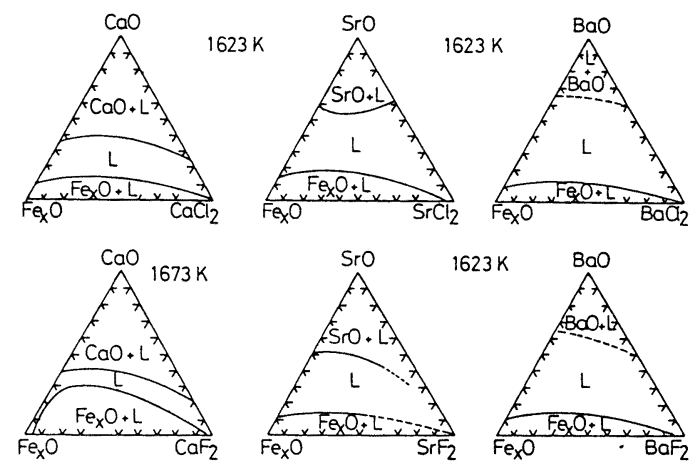

Fig. 2 Phase diagrams of ternary systems, $\mathrm{MO}+\mathrm{MX}_{2}+\mathrm{FeO}$

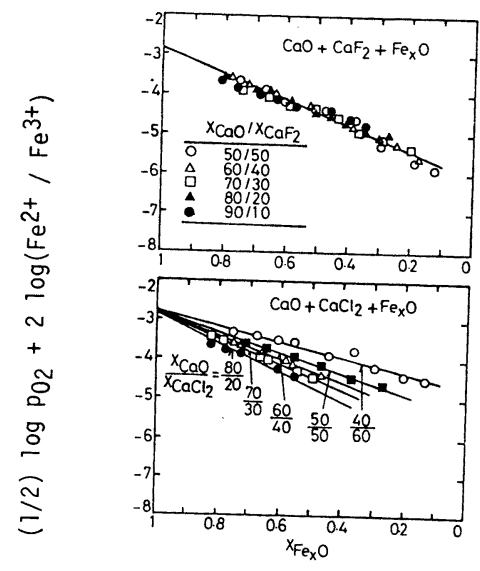

$\mathrm{Fig} .3 \mathrm{Fe}^{2+} / \mathrm{Fe}^{3+}$ equilibria within $\mathrm{MO}+\mathrm{MX}_{2}+\mathrm{FeO}$ melts at $1623 \mathrm{~K}$ 
(288) ルカッ土類化物一嫶化物录フラックス中の $\mathrm{P}_{2} \mathrm{O}_{5}$ の活侢

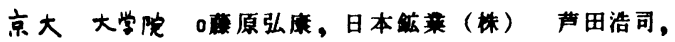

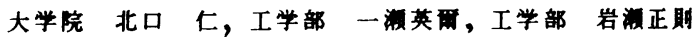

\section{【1粕言】}

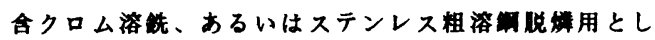
て、見在、 $\mathrm{BaO}+\mathrm{BaCl}_{2}$ 系のフラックスが一部で武用さ れているが、その䓡力学的性共については、ほとんど不 明である。著者らは $\mathrm{BaO}+\mathrm{BaCl}_{2}+\mathrm{P}_{2} \mathrm{O}_{5}$ 系フラックス 中の $\mathrm{P}_{2} \mathrm{O}_{5}$ の活量を测定し、Ca2†イオまよび $\mathrm{F}^{-}$イオ ンの数について本会で報告した/1/ 。今回は、さらに $\mathrm{P}_{2} \mathrm{O}_{5}$ 活量の沮度依存性について抰討した。また、 $\mathrm{CaO}$ $+\mathrm{CaCl}_{2}$ 录フラックスでは $\mathrm{CaO}$ と $4 \mathrm{CaO} . \mathrm{P}_{2} \mathrm{O}$ 5が共存する 時、 $\mathrm{P}_{2} \mathrm{O}_{5}$ の活量は垠も低くる。そこで、次式の $\Delta G^{\circ}$ を测定し、 $\mathrm{CaO}$ 系フラックスの㟋限界を柍㣙した。

$4 \mathrm{CaO}(\mathrm{s})+\mathrm{P}_{2}(\mathrm{~g})+(5 / 2) \mathrm{O}_{2}(\mathrm{~g})=4 \mathrm{CaO} \cdot \mathrm{P}_{2} \mathrm{O}_{5}(\mathrm{~s})$

\section{２実方法】}

\section{$2.1 \mathrm{P}_{2} \mathrm{O}_{5}$ 0活量汐定}

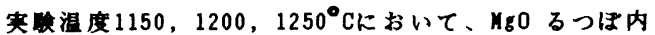
に、 $\mathrm{Cu}-\mathrm{P}$ 合金粎 $200 \mathrm{~g}$ とフラックス䄪 $30 \mathrm{~g}$ を、 $\operatorname{Ar}$ 囲気中で溶解、平淣させ、ジルコニア固体池により平 胃酸菜分压を测定した。同時にメタルサンプルを採取し、 Cい中のPを分析した。

$2.24 \mathrm{CaO}, \mathrm{PaO}_{2}$ の生成自由エネルギーの测定：

この涀定には、起空力法とガス平衡法の両者を併用し た。ガス平解法では、CO 再囲気中、カーボンるつほ内 に、 $\mathrm{Cu}$ - P合金を $\mathrm{CaO}(\mathrm{s}), 4 \mathrm{CaO} . \mathrm{P}_{2} \mathrm{O}_{5}(\mathrm{~s})$ と一楮に溶解 し、所定時间平皃させた後、水中急冾し、メタル中のP を分析した。

\section{【 3 实酸結果】}

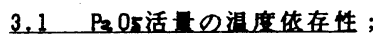

Fig.1に $\mathrm{P}_{2} \mathrm{O}_{5}$ 活量と $\mathrm{P}_{2} \mathrm{O}_{5}$ のルル分率との閶保を示 す。 $\mathrm{P}_{2} \mathrm{O}_{5}$ の活贯が急激に上昇している部分を除けは、 $\mathrm{P}_{2} O_{5}$ の活量は、温度と共に上年しており、100 $\mathrm{C}$ の沮 度上早による活量の上界は、2-3桁である。Fig.2には $\mathrm{P}_{2} \mathrm{O}_{5}$ の通耓の混合自由エネルギ, $\mathrm{R} T \ln \mathrm{X}_{\mathrm{P}_{2} \mathrm{O}_{5}}$, と

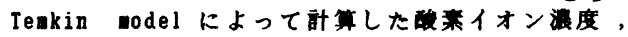
$X\left(0^{2-}\right)$ ，の関保を示すが、スラグ組成、沮度によらず、 $X\left(0^{2-}\right)>0.05$ では

$$
\text { RI } \ln Y_{\mathrm{BO}_{2}}=\mathrm{X}\left(0^{2-}\right)+\mathrm{C} \quad \text { (1, C ; 定数) }
$$

で表わされる。

$3.24 \mathrm{CaO}$. P O Or の生成自由エネルギ二；

Fig.3に $\Delta G^{\circ}$ と沮度の間を係した。本研究のガス 平衡法による結果と、起电力法による結果とは、非常に よく一致している。なお、本研究の值は、Bookey/2/の 值と佐野ら/3/の值の中間にある。

\section{【文蟈】}

/1/著者ら；铁と望 22(1986)S726,S934， 73(1987)S230 /2/ J. B. Bookey; J.I.S.I. 171 (1952)61.

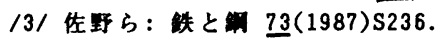

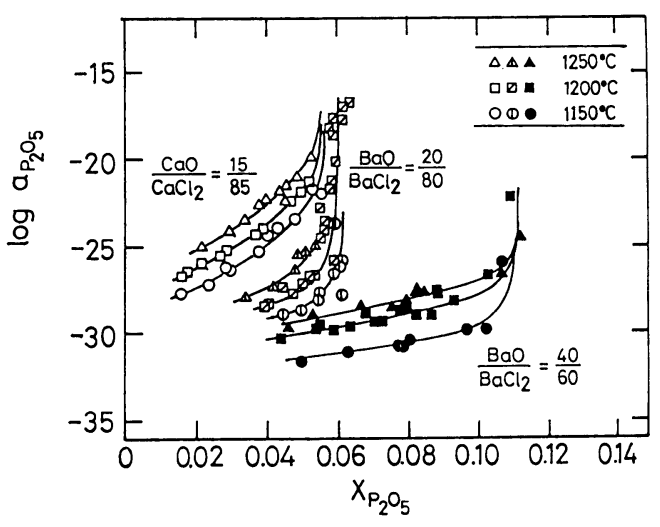

Fig.1 Activity of $\mathrm{P}_{2} \mathrm{O}_{5}$ vs. $\mathrm{P}_{2} \mathrm{O}_{5}$ mole fraction

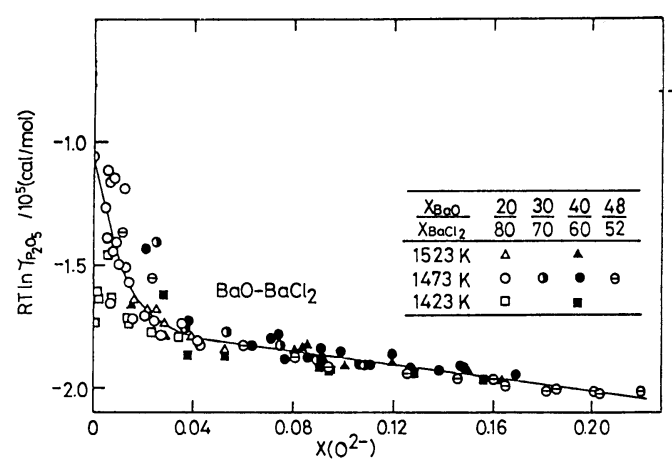

Fig. 2 Activity of $\mathrm{P}_{2} \mathrm{O}_{5}$ vs. oxygen ion fraction

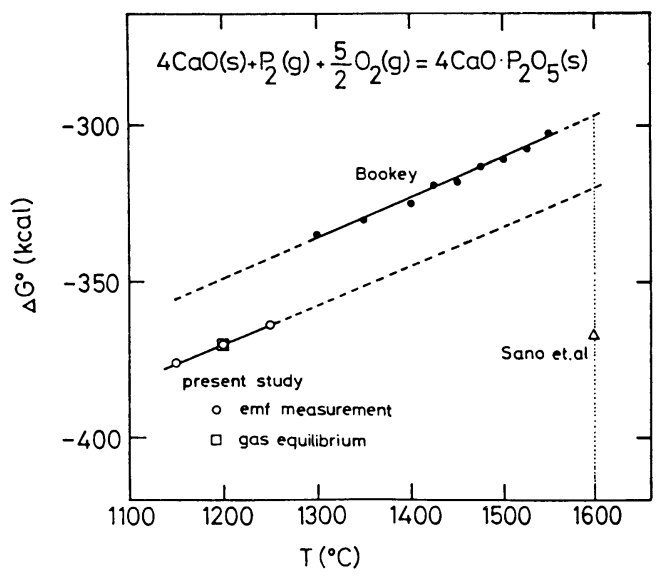

Fig. 3 Free energy of formation of $4 \mathrm{CaO} . \mathrm{P}_{2} \mathrm{O}_{5}$ 
'87- S 1025

(289) F e $e_{t} O-S$ i $O_{2}-M_{n} O-M_{x} O_{y}<M_{x} O_{y}$ $=\mathrm{Na} \mathrm{a}_{2} \mathrm{O}, \mathrm{P}_{2} \mathrm{O}_{5}$ ) 棌スラグ成分の活量 東北大学工学部

萬谷志郎 日野光元

東北大学大学院（現・新日鉄大分） ○江尻满

1.緒言本研究では、銅過程でのマンガン分配に及ぼすスラグ成分の影辢を検討するため、マン ガン分配に大きく影辢する酸化鉄の活量测定を行った。製銅過程でのマンガン分配を考虑する上で基 本系となるのは $\mathrm{F}$ e $\mathrm{t} O \mathrm{O}-\mathrm{S} \mathrm{i} \mathrm{O}_{2}-\mathrm{MnO}$ 系スラグであり、これに溶銑予借処理や溶銅処理の段階で 同時脱りん脱硫郕として添加される $\mathrm{Na}_{2} \mathrm{O}$ を含んだ 4 元系、また、脱りん生成物である $\mathrm{P}_{2} \mathrm{O}_{5}$ を含ん だ 4 元系について、固体鉄、 $\mathrm{H}_{2} \mathrm{O} / \mathrm{H}_{2}$ 混合ガス間との化学平衡を测定した。更に、本系に正則溶液

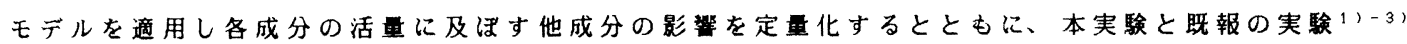
とから得られた結果より、マンガン分配に及ほす $\mathrm{N} \mathrm{a}_{2} \mathrm{O}, \mathrm{P}_{2} \mathrm{O}_{5}$ の影帮を $\mathrm{CaO}, \mathrm{Mg}$ ○と比較して 考察した。

2. 実駼方法所定の組成に配合した 4 元系調合スラグ $4 \mathrm{~g}$ を鉄坩倜中に装入し、電気抵抗炉内で $1673 \mathrm{~K}$ に加熱溶解する。これと一定比の $\mathrm{H}_{2} \mathrm{O} / \mathrm{H}_{2}$ 混合ガスを平衡させ、 $\mathrm{Fe}(\delta)-\left(\mathrm{F} \mathrm{e}_{\mathrm{t}} \mathrm{O}\right.$ $\mathrm{SiO} \mathrm{O}_{2}-\mathrm{MnO}-\mathrm{M}_{\mathrm{x}} \mathrm{O}_{\mathrm{y}}\left(\mathrm{M}_{\mathrm{x}} \mathrm{O}_{\mathrm{y}}=\mathrm{Na} \mathrm{a}_{2} \mathrm{O}, \mathrm{P}_{2} \mathrm{O}_{5}\right)$ 系スラグ $)-\left\{\mathrm{H}_{2} \mathrm{O} / \mathrm{H}_{2}\right\}$ 間の化学 平衡を测定した。予借実駼の結果、平衡到達時間は $\mathrm{N} \mathrm{a}_{2} \mathrm{O}$ 添加系で 8 時間、 $\mathrm{P}_{2} \mathrm{O}_{5}$ 添加系で 7 時間で 十分であることがわかった。平衡到達後、スラグ試料を A r 第囲気で急冷し、粉碎、磁選後に、F $\mathrm{e}^{2+}$ 全鉄, $\mathrm{S} i \mathrm{O}_{2}, \mathrm{Mn}, \mathrm{Na}, \mathrm{P}$ について定量分析を行った。

3. 実駼結果及び考察固体鉄と平衡する溶融スラグ中の酸化鉄と $\mathrm{H}_{2} \mathrm{O} / \mathrm{H}_{2}$ 混合ガス問の化学平衡 は（1）式で示され、その平衡定数は（2）式で示される。

$$
\begin{gathered}
\mathrm{Fe}{ }_{t} \mathrm{O}\left(\iota, \text { in }(\mathrm{ag})+\mathrm{H}_{2}(\mathrm{~g})=\mathbf{t} \mathrm{Fe}(\delta)+\mathrm{H}_{2} \mathrm{O}(\mathrm{g})\right. \\
\mathrm{K}=\left(\mathrm{P}_{\mathrm{H}_{2} \mathrm{O}} / \mathrm{P}_{\mathrm{H}_{2}}\right) / \mathrm{a}_{\mathrm{Fe}_{\mathrm{t}} \mathrm{O}}
\end{gathered}
$$

萬谷ら“は $1673 \mathrm{~K}$ で、 $\mathrm{K}=0.8754$ を得ており、この值と $\mathrm{H}_{2} \mathrm{O} / \mathrm{H}_{2}$ 混合ガス比から $\mathrm{a}_{\mathrm{Fe}_{\mathrm{t}} \mathrm{O}}$ を求めた。 本実験で得られた $\mathrm{N}_{\mathrm{Na}_{2} \mathrm{O}}=0.135$ 及び $\mathrm{N}_{\mathrm{P}_{2} \mathrm{O}_{5}}=0.033$ の等灌度面における $\mathrm{a}_{\mathrm{Fe}_{\mathrm{t}} \mathrm{O}}$ のスラグ組成侬存性を $\mathrm{Fig}$. 1亿示した。また、 $\mathrm{Fe}^{3+} / \mathrm{Fe}^{2+}$ 比の組成依存性を求め、得られた結果に正則溶液モデルを適 用し、 $\mathrm{Na}_{2} \mathrm{O}$ 系、 $\mathrm{P}_{2} \mathrm{O}_{5}$ 系のいずれにおいてもモテルとの整合性がょいことが判明した。これより、 正則溶液モテルを用い $\mathrm{Mn}^{2+}-\mathrm{Na}^{+}, \mathrm{Mn}^{2+}-\mathrm{P}^{5+}$ 間の相互作用エネルギーの值を算出し、これまで に著者らが求めた相互作用エネルギ一の値と組合せて、本系スラグ中の各成分の活量を算出した結果、 $\mathrm{a}_{\mathrm{Fe}_{\mathrm{t}} \mathrm{O}}$ の計算值と测定値は良く一致した。これょり、正則溶液モデを用いて溶融シリケート中の

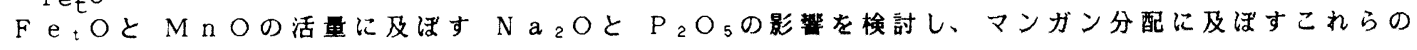

影䇾の连いを定量的に考察した。

\section{参考文献}

1) 萬谷志郎, 日野光匹, 湯下憲吉

：鉄と鋼，71(1985),p．853

2 ）萬谷志郎, 日野光儿, 湯下害吉

：鉄と鍓，71(1985)， S933

3) 萬谷志郎, 日野光儿, 江尻满

：铁と銿，72(1986)，S223

4 ) 萬谷志郎, 渡部忠男

：鉄と銅，63(1977),p.1809
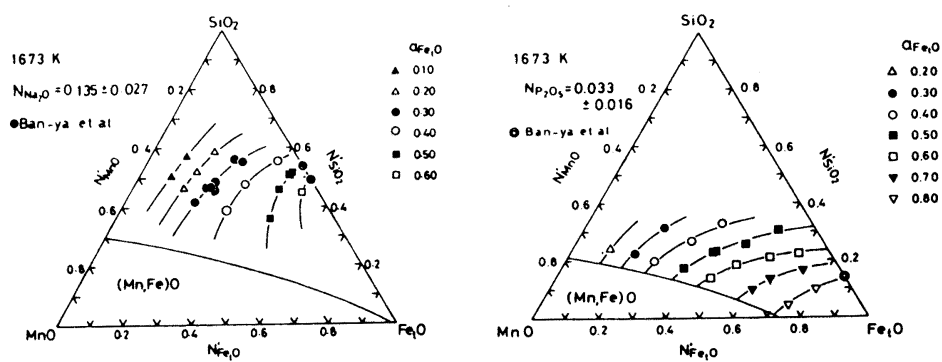

Fig. 1. Iso-activity curves of $\mathrm{Fe}_{t} \mathrm{O}$ on the iso-concentration planes of $\mathrm{N}_{\mathrm{Na}_{2} \mathrm{O}}=0.135$ and $\mathrm{N}_{\mathrm{P}_{2} \mathrm{O}_{5}}=0.033$ at $1673 \mathrm{~K}$. 
（290）溶融ニツッルの珪䒱脱酸

東北大学工学部回井不二夫

萬谷 志郎

緒言： $\mathrm{N}$ i 系合金はバーマロイのように電子・磁性材料として従来より使用されているが、近年、電 子産業が高い成長を続けるなかで、電子部品の主要材料としてその需要が急增している。他方、同合金 は耐熱・耐食材料として優れた特性を示し、航空榊用タービン、熱交換器材等には不可欠の材料である。 しかしながら、 $\mathrm{N}$ i 合金の製造では $\mathrm{C}, \mathrm{O} ， \mathrm{~N}, \mathrm{~S}$ など微量不純物元素の除去、殊に酸素の除去は重要 であるが、Niに関する基碳的研究は少なく、熱力学的资料は不足している。

著者らは先にN i 合金の窒素溶解度について報告"ししたが、本研究は容融 N i の眖酸に䦕する研究と して珪素を取り上げ、S i O2和における珪素一酸素の平衙䦕係を明らかにすることを目的としたもの である。

実駼方法：装固は前報2゙に使用したものと同一であり、A r と $\mathrm{H} 2$ は市䝮のホンベガスを精製して100

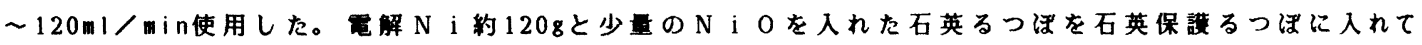
反応管内に設置し、A r を普入して楁解する。試料楁解後、所定の温度に保持してから、内径約 3 mの 石英管で脱酸用添加前の分析試料を採取する。その後、直ちに珪素(99.99mass\%)を添加し、所定の时

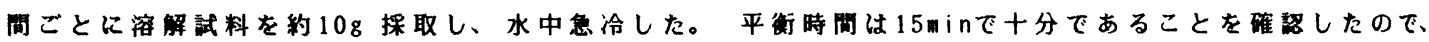

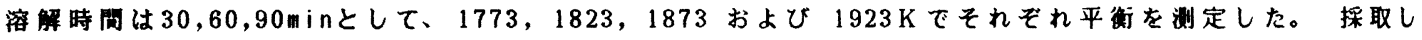
た試料中の酸素定量にはアルコン送気電量溂定装置、また珪素定量にはICP蠚置(ICAP-500)を用いた。

結果と考察：珪素による溶融 N i の眖酸反态式は(1)式で示され、その平衡定数 $\mathrm{K} は(2)$ 式で表される。

$$
\begin{aligned}
& \mathrm{Si} \mathrm{O}_{2}(\mathrm{~S})=\underline{\mathrm{Si}}+2 \underline{\mathrm{O}} \\
& \mathrm{K}=\mathrm{a}_{\mathrm{si}} \cdot \mathrm{a}_{0}{ }^{2} / \mathrm{a}_{\mathrm{SiO}_{2}}
\end{aligned}
$$

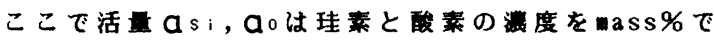
それぞれ表し、活量の基準を繁限希藻溶液にとり、

活量 $\mathrm{QS} \mathrm{O}_{2}$ は固体 $\mathrm{S}$ i $\mathrm{O}_{2}$ 基準をとった。本研究 では $a_{s i O_{2}}=1$ とすれば(2)式は（3）式となり、珪素

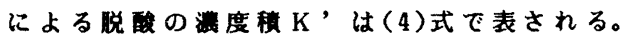

$$
\begin{aligned}
\mathrm{K} & =\mathrm{a}_{\mathrm{si}} \cdot \mathrm{a}_{0^{2}} \\
& =\mathrm{f} \mathrm{si}[\operatorname{mass} \% \mathrm{si}] \cdot \mathrm{f} 0^{2}[\operatorname{mass} \% 0]^{2} \\
\mathrm{~K} & =[\operatorname{mass} \% \mathrm{si}] \cdot[\operatorname{mass} \% 0]^{2}
\end{aligned}
$$

测定結果より $10 \mathrm{~g} \mathrm{~K}$ 'と珪素灌度の関係をFig，1に 示す。直線の勾配に温度侬存性がないむのとして各 直線は(5)式で表され、標準虔差は $\alpha= \pm 0.084$ 以下であった。

$$
\log \mathrm{K}^{\prime}=\log \mathrm{K}-0.06 \text { [ mass\% } \% \text { Si] }
$$

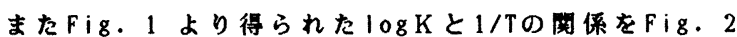
に従来の報告值と比效して示し、108 Kの温度式とし て次の結果を得た。

$$
\log \mathrm{K}=-15680 / \mathrm{T}+1.83
$$

考文献：1) C.K.Kim,A.McLean,F.Ishii and S.Ban-ya: I \& SM(1986,0ct)p.43/49

2) 石井, 井口, 萬谷：铁と錆, 69(1983)p.913/920

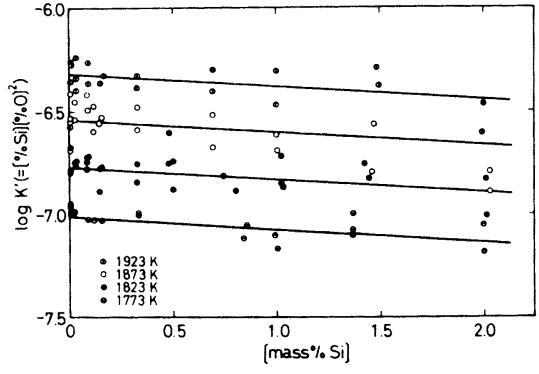

Fig. 1. Effect of silicon on $\log K^{\prime}$.

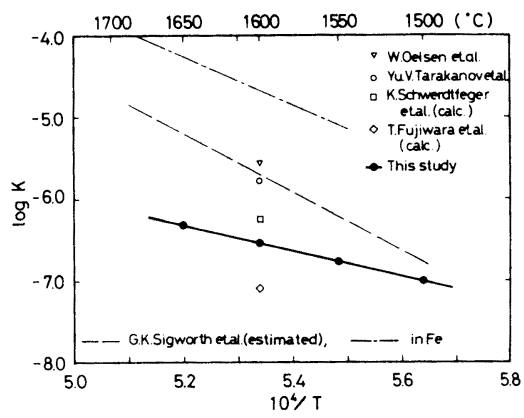

Fig. 2. Temperature dependence of $\log \mathrm{K}$. 
(291) 低酸秦A1キルドの溶製に通したスラク組成の㛟討

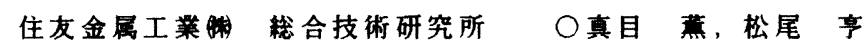

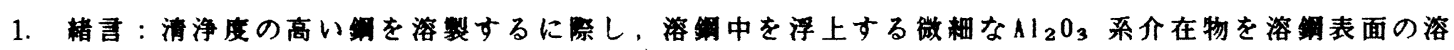

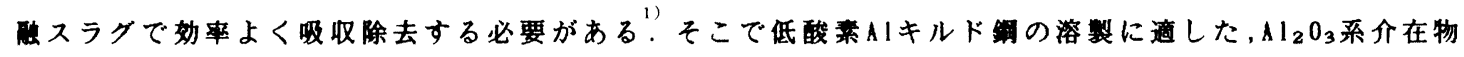
の吸収能の高いスラク租成の模討を行なった。 $\mathrm{Al}_{2} \mathrm{O}_{3}$ 系介在物吸収能の高いスラグとは，1)固体 $\mathrm{Al}_{2} \mathrm{O}_{3}$ と溶融スラク间の界面張力が小さく， $\mathrm{Al}_{2} \mathrm{O}_{3}$ の付举が容易であること，2)付着した $\mathrm{Al}_{2} \mathrm{O}_{3}$ を容易に吸収 染解できる $\left(\mathrm{Al}_{2} \mathrm{O}_{3}\right.$ 溶解速度が大きい)ことの 2 条件を满足するスラ グを意味するものと考え，各々の測定を行ない，更に溶䧓に添加し てその脱䣬挙動を調查した。

2 実方法：溶融スラク系としてスラク A ( $\mathrm{CaO}-\mathrm{CaP}_{2}-\mathrm{Al}_{2} \mathrm{O}_{3}$ 系) 及びスラク B ( $\mathrm{CaO}_{0}-\mathrm{CaF}_{2}-\mathrm{SiO}_{2}$ 系) をそれぞれ実联前にプリメルトし

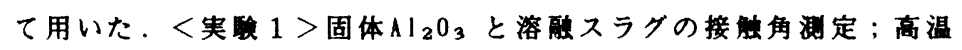

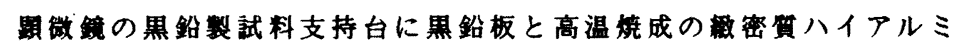
十板を並べておき，黒铅板上で溶融球状化させたスラクを，支持台 を㑯けて $\mathrm{Al}_{2} \mathrm{O}_{3}$ 板上に移動させて固体 $\mathrm{Al}_{2} \mathrm{O}_{3}$ と溶融スラグ间の接触 角の時间推移を湖定した。<実梌 $2>$ 溶融スラクの固体 $\mathrm{Al}_{2} \mathrm{O}_{3}$ 溶解

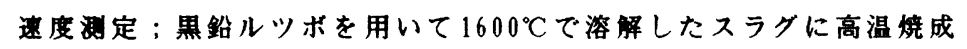
高アルミ十円盤 $(50.85 \phi \times 5 \mathrm{t})$ を $100 \mathrm{rpm}$ 速度で浸清回転させ，円

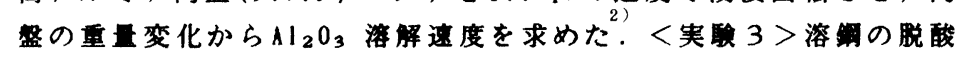
挙勁調查； $1600^{\circ} \mathrm{C}$ に保持した $1 \% \mathrm{C}$ 溶佣 $1.5 \mathrm{t}$ に所定のスラク $40 \mathrm{~kg} / \mathrm{t}$ を添加し，マグクロ面耐火物での低酸素A1キルド成の溶製を行なっ た.

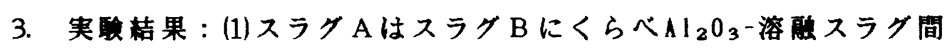
の接触角が小さい(Fig.1)，スラグ A は配合 $\mathrm{Ca}_{2}$ 量を大きく，配合 㙁基度を高くする程，接触角が小さくなる。一方スラク Bは眍合 $\mathrm{CaF}_{2}$ 量を大きくすると接触角が小さくなるが配合塩基度を高くする と接角は大きくなった。(2)スラグ A はラクタにくらべ $\mathrm{Al}_{2} \mathrm{O}_{3}$ 溶

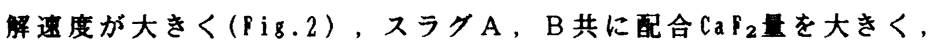
配合㙁基度を高くする程， $\mathrm{Al}_{2} \mathrm{O}_{3}$ 溶解速度は大きくなった。(引) スラ

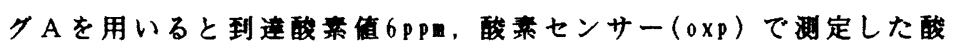

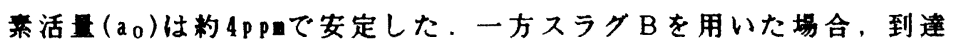

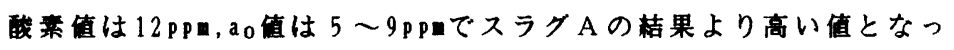
た. (Fig.3)

4. 絬言：固体 $\mathrm{Al}_{2} \mathrm{O}_{3}$ と付畕し易く，かつ固体 $\mathrm{Al}_{2} \mathrm{O}_{3}$ を溶解する速 度の大きいスラク $\left(\mathrm{Al}_{2} \mathrm{O}_{3}\right.$ 吸叹能の高いスラグ)系は, $\mathrm{CaO}-\mathrm{CaP}_{2}-\mathrm{Al}_{2} \mathrm{O}_{3}$ 系であり，配合 $\mathrm{Ca}_{2}$ 量を大きく，また配合垭基度を高くすることに より $\mathrm{Al}_{2} \mathrm{O}_{3}$ 吸収能を向上できる。低酸素 $\mathrm{Al}$ キルド成溶製には， $\mathrm{CaO}$ $-\mathrm{CaP}_{2}-\mathrm{Al}_{2} \mathrm{O}_{3}$ 系スラグを用いると脱酸举動は安定し, 到達酸素值を 低くすることができる。

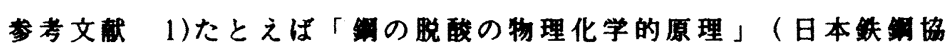

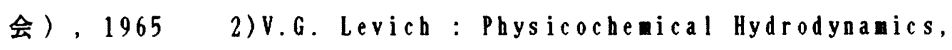
Prentice-Hall Englewood Cliffs, N, J, 1962

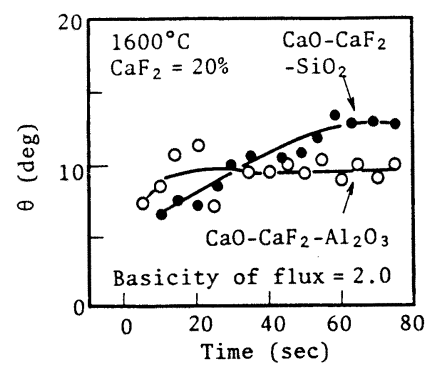

Pig.l Behaviours of wetting angle between solid $\mathrm{Al}_{2} \mathrm{O}_{3}$ and liquid slag at $1600^{\circ} \mathrm{C}$

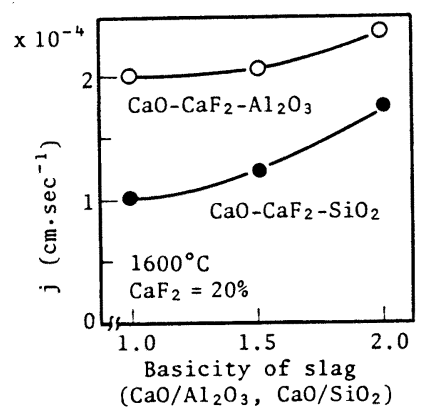

Pig. 2 Relationship between basicity of slag and $\mathrm{Al}_{2} \mathrm{O}_{3}$ solution rate into liquid slag at $1600{ }^{\circ} \mathrm{C}$

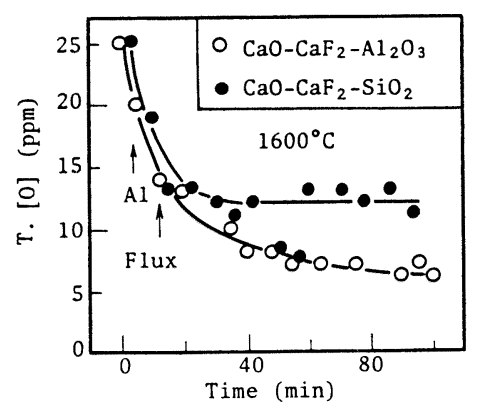

Pig. 3 Influence of slag system on the deoxidation of $1 \% \mathrm{C}$ steel (2.5t furnace) 
（292）溶融 $\mathrm{Fe}-\mathrm{Cr}$ 合金と $\mathrm{Ca} 0-\mathrm{Al}_{2} \mathrm{O}_{3}$ 基スラグ間のクロム招よび硫黄分配

室闌工大 ○片山 博 曹 定 松島 直司

\section{1. 緒言}

高クロム鋼の取鋼精錬を対象として、低酸素ポテンシャル下におけるメタルースラグ間の分配平衡を 測定した研究は見当らない。本研究では、 $\mathrm{Fe}-\mathrm{Cr}$ 合金と $\mathrm{Ca} 0-\mathrm{Al}_{2} \mathrm{O}_{3}$ 基の $\mathrm{Ca} 0-\mathrm{Mg}_{2}-\mathrm{Al}_{2} \mathrm{O}_{3}-\mathrm{SiO}_{2}$ 系スラ グ間のクロム扔よび硫黄分配を測定するとともに、スラグ中のCr0の活量保数を求めた。ついで、それら を温度、メタル打よびスラグ組成の関数として解析し、それぞれの実験式を導き出した。

\section{2 . 実験方法}

メタル試料は $0.12 \% \mathrm{~S}$ 含み、Cr濃度を約 $8.5 \%$ 2 $17 \%$ の 2 レベルに変化させた。スラグはあらかじめ 溶製した 4 種の母スラグを種々の割合に配合し組成を变化させた。Ca0 : 33〜 46\%, Mg0 : 10〜15\%, $\mathrm{Al}_{2} \mathrm{O}_{3}: 28 \sim 49 \%, \mathrm{Si}_{2}: 1 \sim 20 \%$ 。メタル試料 $25 \mathrm{~g}$ 、スラグ試料 $7 \mathrm{~g}$ 文密質のマグネシアるつほに入れ、 精製 $A r$ 雾囲気中 $1575 、 1600 、 1650^{\circ} \mathrm{C}$ 各温度にて通常4.5h溶解した。

\section{3 . 結果}

熱力学的検討の結果から、本実験条件下に打けるメタルースラグ間のクロム怙よび酸素分配を次の反 応に基ずいて検討した。 $\quad(\mathrm{Cr} 0)=[\mathrm{Cr}]+[0] \quad$ (1) $\quad \log \mathrm{K}=-12430 / \mathrm{T}+5.738$ メタル中の酸素濃度を温度、メタルおよびスラグ組成の関数として重回帰法により解析し次式を得た。

$$
\log [\% 0]=0.413 \log \mathrm{N}_{\mathrm{Cr} 0}+0.0065[\% \mathrm{Cr}]-0.091 \Sigma \mathrm{K}_{\mathrm{i}} \mathrm{N}_{\mathrm{i}}-13044 / \mathrm{T}+5.574
$$

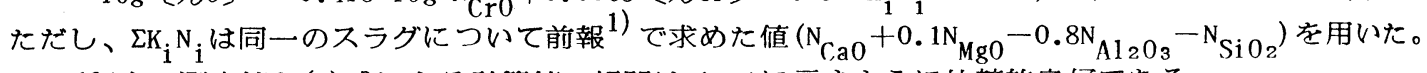

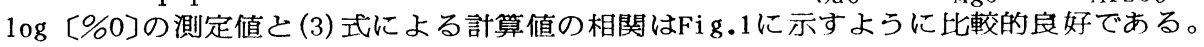

メタルースラグ間のクロム分配比 $\mathrm{Cr}_{\mathrm{Cr}}(=(\% \mathrm{Cr}) /[\% \mathrm{Cr}])$ についても上記と同様の方法により解析し 次式を得た。

$$
\log \mathrm{L}_{\mathrm{Cr}}=2.04 \log \mathrm{N}_{\mathrm{Cr} 0}-0.037[\% \mathrm{Cr}]-0.037 \Sigma \mathrm{K}_{\mathrm{i}} \mathrm{N}_{\mathrm{i}}+825 / \mathrm{T}+0.878
$$

$108 \mathrm{~L}_{\mathrm{Cr}}$ の測定値と (4) 式による計算値の比較をFig.2に示す。両者の相関は非常に良好である。

スラグ中のCroの活量係数 $\mathrm{Cr} 0$ は (2) 式を用いて求めた。得られた $\mathrm{Cr}_{0}$ 值を上記と同様の方法により解 析し次式を得た。

$$
\log \gamma_{\mathrm{CrO}}=-0.561 \log \mathrm{N}_{\mathrm{Cr} 0}-0.096 \Sigma \mathrm{K}_{\mathrm{i}} \mathrm{N}_{\mathrm{i}}-3044 / \mathrm{T}+1.528
$$

Fig.3に示されるように、(2) 式により求めた $\gamma_{\mathrm{Cr} 0}$ と (5) 式による計算值の相関はかなり良好である。

以上のほか、硫黄分配比についても上記と同様に解析し実験式を導いた。

1) T. Tsao and H. G. Katayama : Trans. ISIJ, p. 717.

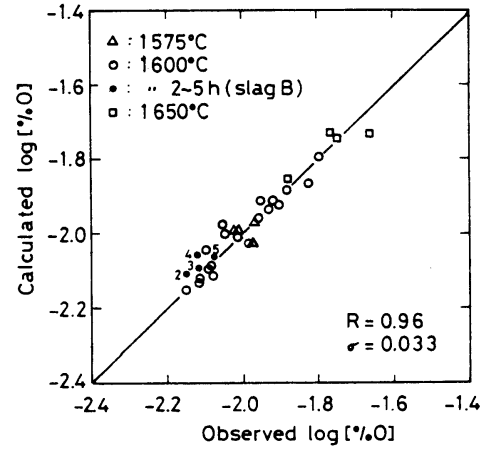

Fig.1. Comparison of observed [\% $\%$ ] with $[\% 0]$ calculated from Eq. (3).

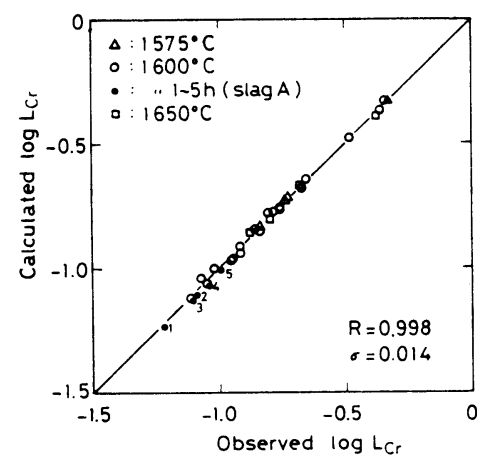

Fig.2. Comparison of observed ${ }^{\mathrm{L}} \mathrm{Cr}$ with $\mathrm{L}_{\mathrm{Cr}}$ calculated from Eq. (4).

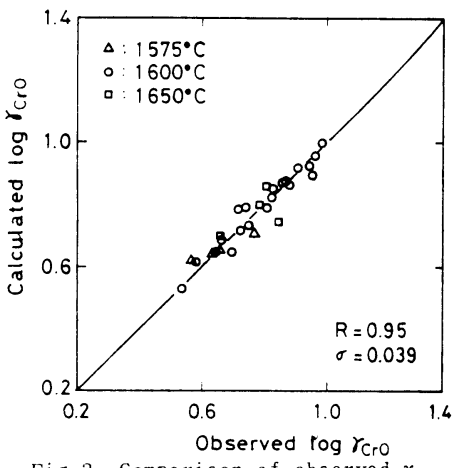

Fig.3. Comparison of observed $\gamma_{\mathrm{Cr} 0}$ with $\gamma_{\mathrm{CrO}}$ calculated from Eq. (5). 
(*) Department of Metallurgy, University of Tokyo (On leave of absence from COSIPA - Brazil)

$(\star *)$ Institute of Industrial Science, University of Tokyo

$(\star \star \star)$ Faculty of Engineering, University of Tokyo

\section{Introduction}

Hot metal pretreatment is usually carried out in ladles or torpedo cars lined with aluminabased or magnesia-based refractories. Furthermore, in practical operation it is very common that some amount of blast furnace slag remains in the vessel even after slag-off operation. Therefore in industrial processes some degree of contamination of added fluxes for pretreatment is unavoidable. In the previous work $(1)$, the sulphide capacity $\left(\mathrm{C}_{\mathrm{S}^{2-}}\right)$ of $\mathrm{CaO}-\mathrm{CaF}_{2}-\mathrm{SiO}_{2}$ ternary fluxes were determined at temperatures ranging from 1200 to $1350^{\circ} \mathrm{C}$ showing that lime saturated compositions have outstanding desulphurization capabilities. In this work the influences of $\mathrm{MgO}$ and $\mathrm{Al}_{2} \mathrm{O}_{3}$ on the sulphide capacity of $\mathrm{CaO}-\mathrm{CaF}_{2}-\mathrm{SiO}_{2}$ fluxes were investigated.

\section{Experimental procedure}

The method employed is the same as the previous work namely flux and molten silver were equilibrated under controlled atmosphere. The fundamental reaction and the equation for determining $\mathrm{C}_{\mathrm{S}^{2}}$ - are expressed by (1) and (2).

$[\mathrm{S}]+\left(\mathrm{O}^{2-}\right)=1 / 2\left\{\mathrm{O}_{2}\right\}+\left(\mathrm{S}^{2-}\right) \ldots(1)$

$\mathrm{C}_{\mathrm{S}}{ }^{2-}=\mathrm{K} \cdot \mathrm{pO}_{2}^{1 / 2} \cdot \mathrm{z}\left(\mathrm{S}^{2-}\right) / 8[\mathrm{~S}] \quad \ldots(2)$

3. Results

Figure 1 shows the influence of partial substitution of $\mathrm{CaO}$ by $\mathrm{MgO}$ on $\mathrm{C}_{\mathrm{S}} 2$ - of the $\mathrm{CaO}-$ $\mathrm{CaF}_{2}-\mathrm{SiO}_{2}$ ternary flux $(8 \mathrm{MgO}+8 \mathrm{CaO}=56)$. It is confirmed that MgO is weaker desulphurizer than $\mathrm{CaO}$ but its effect depends on the flux composition, especially on $\mathrm{CaO} / \mathrm{SiO}_{2}$ ratio. This can be seen by comparing Figure 1 with

Figure 2 (flux with $8 \mathrm{MgO}+8 \mathrm{CaO}=64)$. As can be seen $\mathrm{C}_{\mathrm{S}} 2$ - decreases with increasing MgO content and this is more pronounced at higher $\mathrm{CaO}-\mathrm{SiO}_{2}$ ratio. The influence of $\mathrm{Al}_{2} \mathrm{O}_{3}$ on $\mathrm{C}_{\mathrm{S}} 2$ - of the same flux system is presented in Figure 3 indicating that $\mathrm{C}_{S} 2$-increases when silica is partially replaced by alumina $\left(\mathrm{AAl}_{2} \mathrm{O}_{3}+8 \mathrm{SiO}_{2}=14\right)$. It can be concluded that with higly basic fluxes such as those investigated here $\mathrm{Al}_{2} \mathrm{O}_{3}$ is nearly as acidic as $\mathrm{SiO}_{2}$.

REFERENCE

1) K.Susaki et al: Tetsu-to-Hagane, 73 (1987), $\mathrm{S} 244$

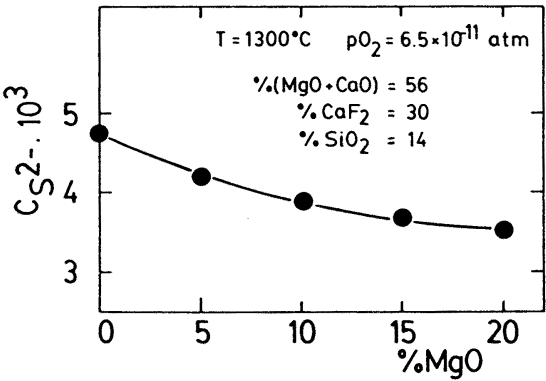

Fig.l Influence of MgO on sulphide capacity of $\mathrm{CaO}-\mathrm{CaF}_{2}-\mathrm{SiO}_{2}$ flux

$(\% \mathrm{CaO}+\mathrm{MgO}=56)$

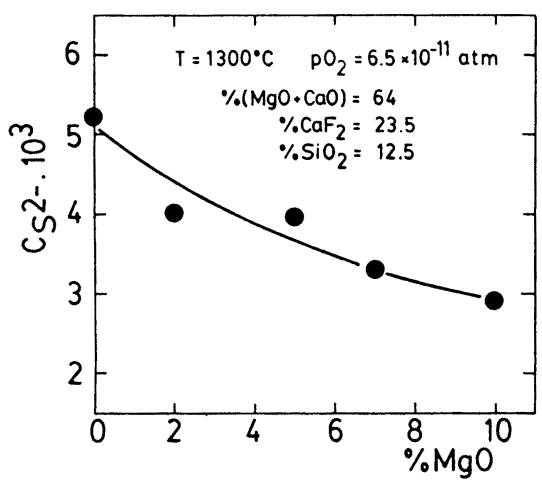

Fig.2 Effect of $\mathrm{MgO}$ on sulphide capacity of $\mathrm{CaO}-\mathrm{CaF}_{2}-\mathrm{SiO}_{2}$ flux $(\% \mathrm{CaO}+\% \mathrm{MgO}=64)$

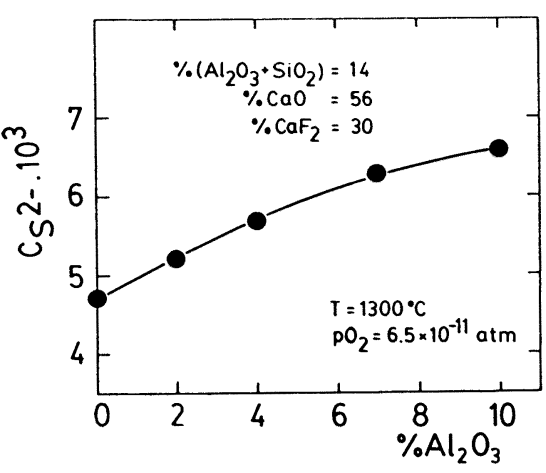

Fig. 3 Influence of $\mathrm{Al}_{2} \mathrm{O}_{3}$ on sulphide capacity of $\mathrm{CaO}-\mathrm{CaF}_{2}-\mathrm{SiO}_{2}$ flux 
(294) C a O - S i O 2 - F e O 系スラダ中への C a Oの溶解に及ぼす超音波の奻果

$$
\begin{aligned}
& \text { 大阪大学工学部 } O \text { 喜多善史 } \\
& \text { 大学院五島章好（現松下留易㜀） } \\
& \text { 工学部森田善一郎 }
\end{aligned}
$$

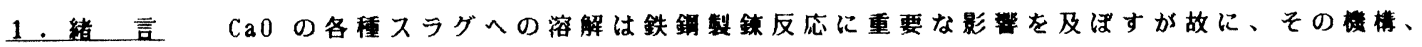
速度に関する研究は従来数多く行われてきた。ところて、著者らは以前に安息香酸の水溶液への楁解 に際して超音波を照射し若干の溶解促進効果を見出した代。そこで本研究においては、制スラクの 基本系である $\mathrm{Ca} 0-\mathrm{Si}_{2} \mathrm{Z}_{2}-\mathrm{Fe} 0$ 系スラグへの $\mathrm{Ca} 0$ の溶解過程に超音波を迶用し、その效果について 実駼的に梌討した。

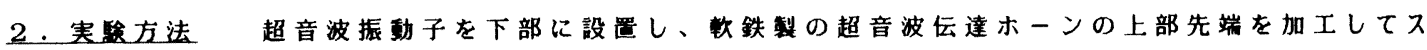
ラグ試料客解るつほとして用いた。测定に際しては先ず予借溶した Ca 0 - Si $02-F e 0$ 系スラグ(

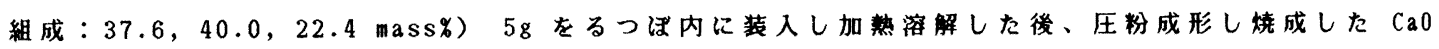
試料をスラグ内に約 $2 \mathrm{~mm}$ 浸演し同時に超音波照射を䦕始した。所定時間保持し溶解させた後、るつ 活を $\mathrm{Ca} 0$ 試料と共に妒内下部に引き下げ、アルコンガスを吹き付け急冷凝固させた。准固試料につい てスラグ中の $\mathrm{Ca} 0$ 渞度を $\mathrm{KMnO}_{4}$ 滴定法により求め、 $\mathrm{Ca} 0$ とスラグとの界面を中心に断面を EPMAおよ

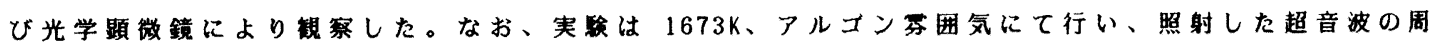
波数は $25 \mathrm{kHz}$ 、高周波出力は $0 \sim 100$ Wであった。

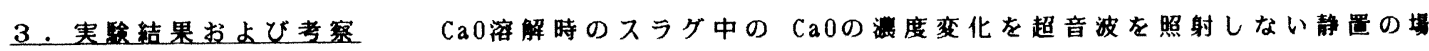
合および超音波 (100W)照射の場合について各々Fig.1（a）および（b）に示した。算度は数個の異な る溶解陚料についての平均値として求め、そのばらつきの籍囲とともに示した。静置の場合にはCa0

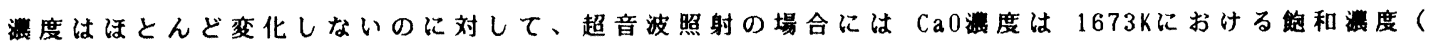
43.0 \%)に向かって增加の傾向を示し、超音波による溶解促進効果を表している。本法のように、楁

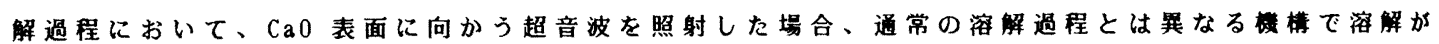
進行すると考えられるが、ここでは従来の解析結果と比较するため、通常の液侧拡散律速に基づく見 かけの物筫移動係数kを求め、Fig.2 に示した。k㹥 $50 \mathrm{~W}$ 以上の超音波照射時において出力の增加 とともに大きくなり、溶解促進効果が認められた。Ca0のスラグへの楁解機棒との関連において超音 波の効果を定量的に論じるにはさらに詳細な検討加必要である。 （1）喜多, 狛谷, 森田：日本金属学会諳演概要 (1987.4), p 317
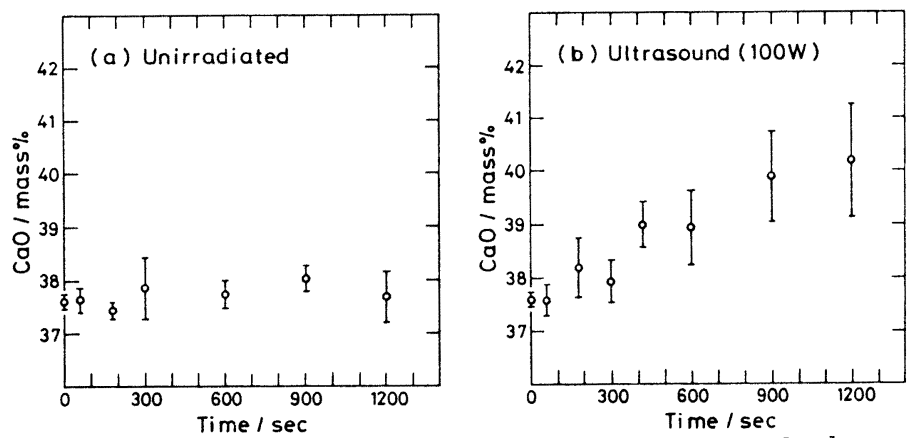

Fig. 1 Change of $\mathrm{CaO}$ concentration in $\mathrm{CaO}-\mathrm{SiO}_{2}-\mathrm{FeO}$ slag during dissolution of CaO. (a) Unirradiated (b) Irradiated with ultrasound (output:100W)

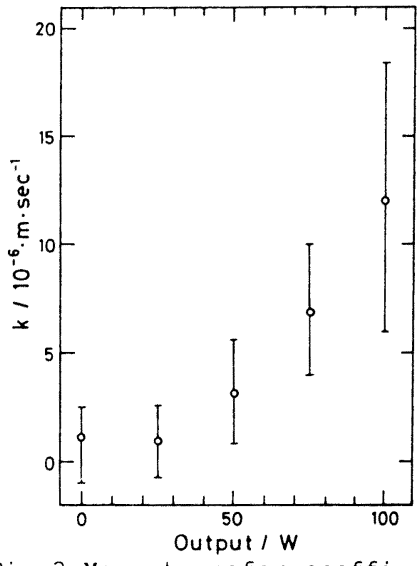

Fig. 2 Mass transfer coefficient $k$ versus output of ultrasonic generator. 
'87-S 1031

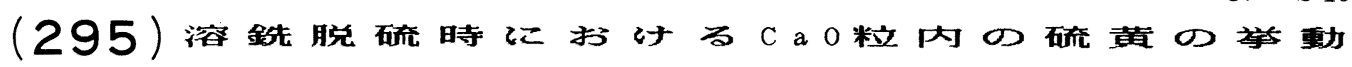

\begin{tabular}{|c|c|c|c|c|}
\hline $\begin{array}{l}\text { 大阪大学 } \\
\text { 大阪大学 } \\
\text { 大阪大学 }\end{array}$ & $\begin{array}{l}\text { 土学部 } \\
\text { 学院 } \\
\text { 工学部 }\end{array}$ & 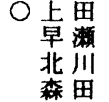 & $\begin{array}{l}\text { 㴖 } \\
\text { 雅之（現 } \\
\text { 逸 朗 } \\
\text { 善一郎 }\end{array}$ & 川崎繁鉄新) \\
\hline
\end{tabular}

[粕言] 涴鉎脱硫時における Ca0系フラックスの挙動解析や、その速度論的考察を行うた めには、固体 $\mathrm{Ca} 0$ 内の硫黄の移䖝速度、および溶銑脱硫時に溶銑成分と平䚘する $\mathrm{Ca} 0$ 粒界面での硫黄灌 度を知ることが重要であると考えられる。しかし従来、これらに関する実测值の報告例はない。

そこで著者らは、楁銑中を浮上する $\mathrm{Ca} 0$ 一粒子をモデルとした $\mathrm{Ca} 0$ 压粉体を用い、 $\mathrm{Ca} 0$ 粒内の硫黄の

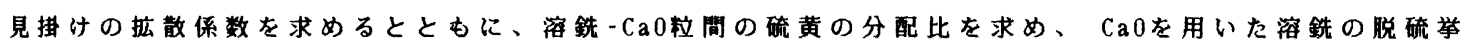
轩の検討を行った。

[実験方法]

1)拡散モデル実期

溶銑脱酼時において溶鉎中の

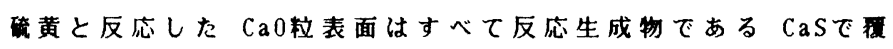
われていると仮定し、CaS層を压着させたCa 0 压粉体を溶銑温

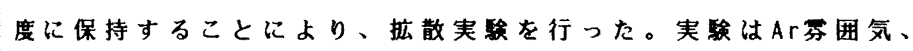
$1673 \mathrm{~K} に$ 保持された炉内に压粉体試料を所定時間挿入すること により行った。その後試料を急冷しEPMA分析によって断面の硫 黄の漕度分布を测定することにより、Ca0粒内の硫黄の見揕け の㹡散係数を求めた。

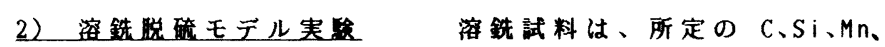
S溜度になるよう溶製した電解鉄を用いた。脱硫実鵌は高周波

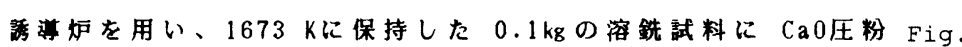
体を14400s（4hr)浸漬させ、その後 $\mathrm{Ca} 0$ 圧粉体を溶鉄より引き

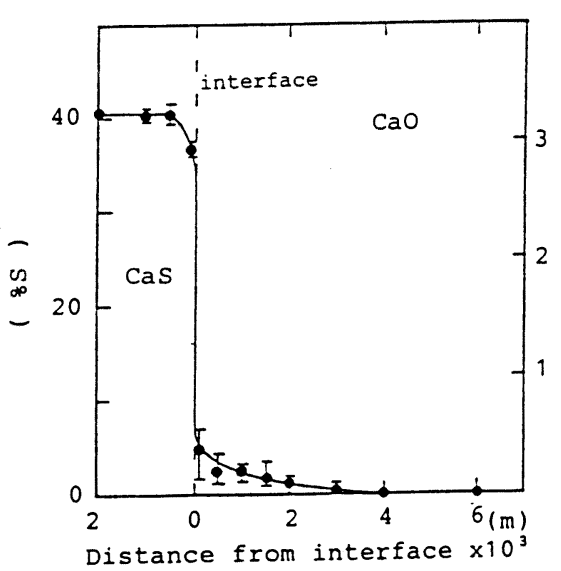
上げ急冷するとともに、石英管にて楁銑を速やかに吸引採取し、 それぞれをEPMA、化学分析により各成分䪰度を決定した。 [実雅結果] 拡散実結果の一例として、 $172,800 \mathrm{~s}(48 \mathrm{hr})$ 保持後のCa 0 単味压粉体試料内の硫

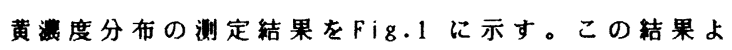
り界面での硫黄の見津けの拡散係数を求めると、 $1 \times 10^{-13}\left(\mathrm{~m}^{2} / \mathrm{s}\right)$ となった。また同梯の方法により Ca0-5 mo1\% $\mathrm{CaF}_{2}$ および $\mathrm{Ca} 0-10$ mo1\% $\mathrm{CaF}_{2}$ フラックス 内の硫黄の見措けの拡散係数を求めると、それぞれ $5 \times 10^{-12}\left(\mathrm{~m}^{2} / \mathrm{s}\right)$ と $1 \times 10^{-11}\left(\mathrm{~m}^{2} / \mathrm{s}\right)$ の值を得た。

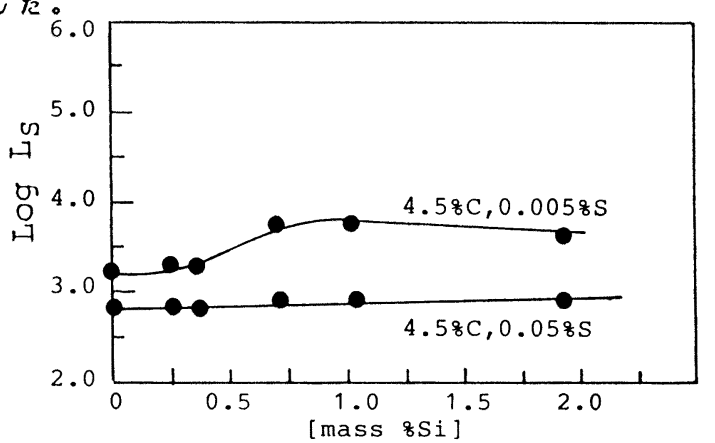

脱酼実結果の一例として硫黄の分配比(Ls)にFig.2 Relation between log Ls and [mass8si].

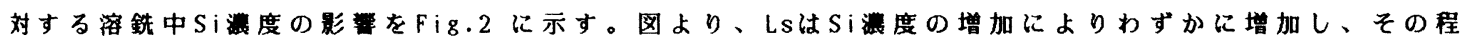

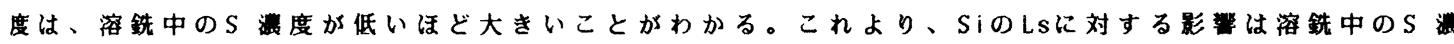
度によって左右されることがわかった。したがって低硫黄銑の場合、Siの存在は眖硫に有利であるが、 高硫黄銑においてはSiの影管は小さいと推定される。 


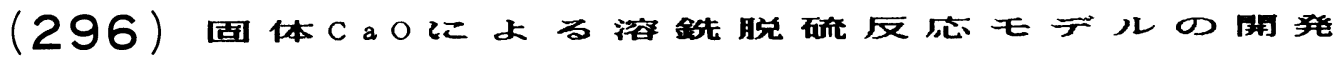

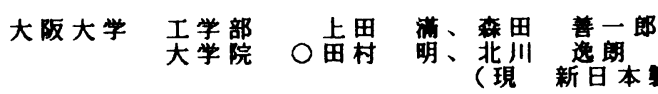

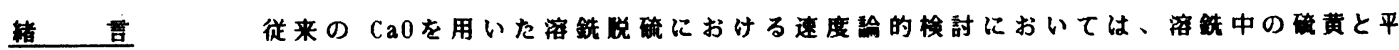

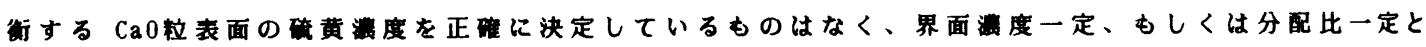

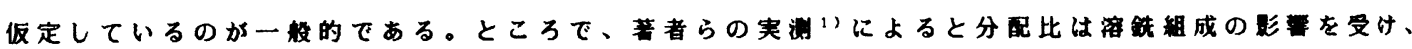

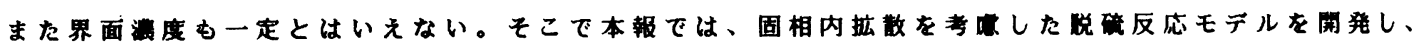

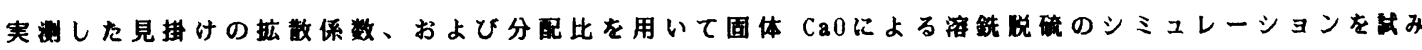

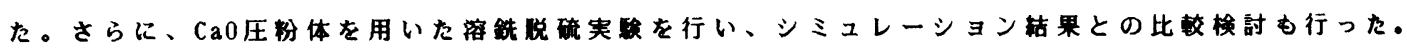

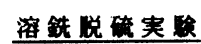

炭車的和鉄およびこれにSiあるいはMnを添加したものを淄鉄試料として用い

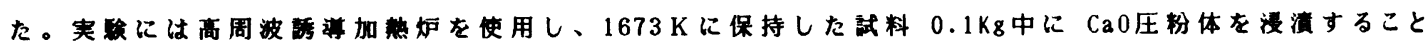

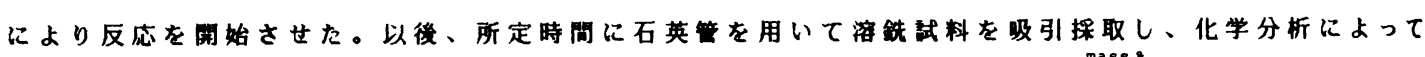
磁黄潧度を決定した。

反応モテルの道用固相内搪散を考礼し、 かつ多成分の物筫移助をむ考想した本モテルは、 以下のような仮定に基ついている。

1.界面での化学反度速度は速く、平衙加成立。 2.界面の平衡酸ホテンシャルは各成分に共通。

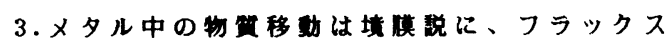
中では非定常厸散のFickの法則に従う。

4.メタル中の物移就係数およびフラックス中 の拡散係数は全成分で等しい。 mass

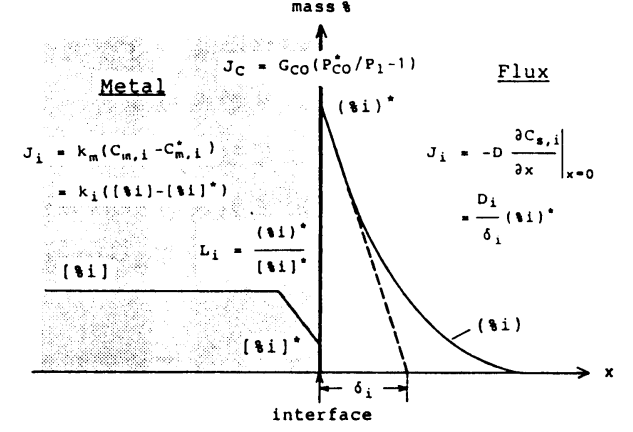

Fig.1 Schematic diagram of concentration profile considered in kinetic model.

5. 反応はカッフリング反応で、昰気的中性条件を清たしなから進行する。

Fig.1に、本モテルにおける考え方の略略を示す。海鉄成分として、Fe、C、S、Si、Mn、0を考元、気的中 性条件を满たすという仮定から、これらの物算移流束阙には次式加成立する。

$$
J_{F}+J_{c}-J_{s}+2 J_{s i}+J_{M n}-J_{0}=0
$$

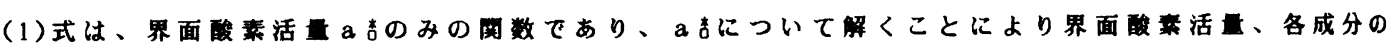

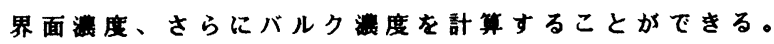

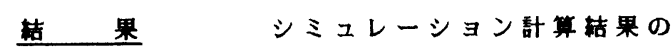

一例として、Si初渞度を変化させたときの客鉄中

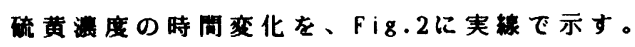

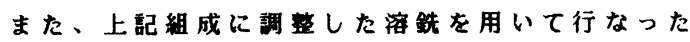
帨硫実結果むあわせて示した。いずれの塄合む、 本モデルによるシミュレーション結果は実酸植を よく再現していることがわかる。

さらに、物算移的係数、反応界面稹を变化させ

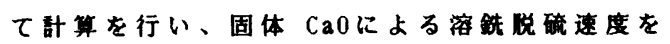
支眍する因子について梌时を行った。

（参考文献）1）上田万：本涳大会発表予定

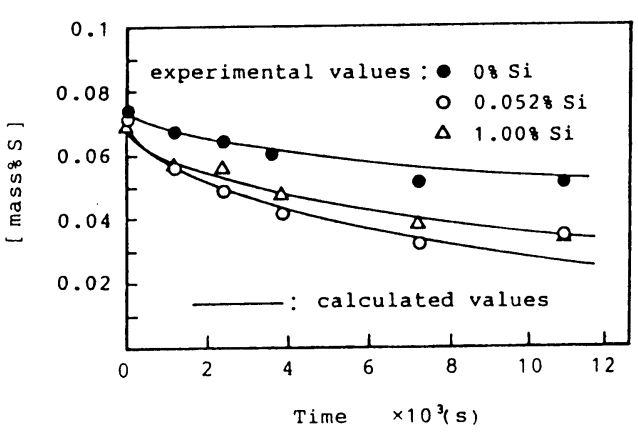

Fig.2 Simulation of desulphurization. 
' $87-\mathrm{S} 1033$

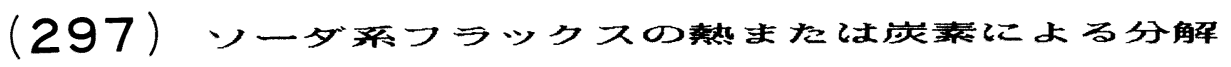

反心速度および溶鉄との反心

鉄錭短大 $\bigcirc$ 国定京治岩井应哉

\section{1. 绪 言}

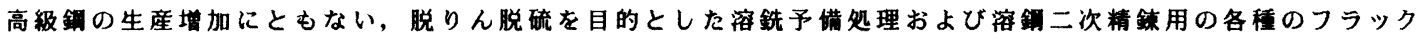
スが研究䦕発されているが,これらのフラックスの脱りん脱硫以外の冶金特性は不明なものが多い。本研究では, ソータ灰 ( $\left.\mathrm{Na}_{2} \mathrm{C}_{3}\right)$ および $\mathrm{Na}_{2} 0-\mathrm{Si}_{2}$ 系フラックスについて熟および炭素（固体炭素, 溶鉄中炭素）による分 解反応を取り上げ，速度論的解析を行った。また，これらのフラックスと溶鉄との反応にっいて調べた。

\section{2. 実駼方法}

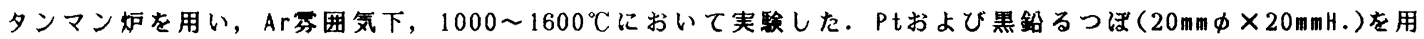
い,フラックス（ $3,5 \mathrm{~g})$ の重量変化をロードセルで検出した。溶鉄中炭素との反応の場合は, Fe-C合金 $10 \mathrm{~g}$ を

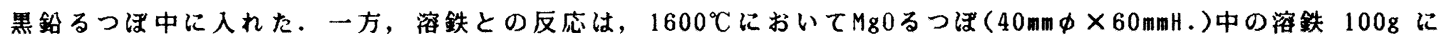
$\mathrm{Na} 20-\mathrm{SiO}_{02}$ フラックス $20 \mathrm{~g}$ を添加し, 得られたスラグ組成と等度から解析した。

\section{3. 実験結果および考察}

(1)熱分解反応： $\mathrm{Na}_{2} \mathrm{CO}_{3}$ および $\mathrm{Na}_{2} \mathrm{O}-\mathrm{SiO}_{2} \mathrm{flux}_{(\mathrm{ua}} \mathrm{O} / \mathrm{SiO}_{2}$ (モ ル比) $=B=2,1.5,1)$ 熱分解による減量の様子をFig.1に示す. これらのフラックスの分解反応（減量）速度 $w\left[\mathrm{~kg} / \mathrm{m}^{2} \cdot \mathrm{s}\right]$ を求 め, この対数值と $1 / \mathrm{T}$ 関係を $\mathrm{Fig} .2$ に示す. なお, $\mathrm{Na}_{2} 0 / \mathrm{SiO}_{2}=$

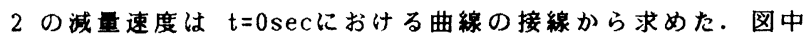
の破線は, 中村ら”の求めた $\mathrm{Na}_{2} \mathrm{C}_{3}$ の結果であり, 本結果は これとよく一致している. 本結果は，(1)，(2)式で表せる.

なお，B=1の Na20-SiO2fluxはほとんど減量が起こらなかった。 $\mathrm{Na}_{2} \mathrm{C}_{3}: w=6.05 \times 10^{3} \exp (-57300 / \mathrm{RT})\left[\mathrm{kg} / \mathrm{m}^{2} . \mathrm{s}\right] \ldots \ldots$ (1) $\mathrm{Na}_{2} 0-\mathrm{SiO}_{2}(\mathrm{~B}=2): w=6.80 \times 10^{3} \exp (-51500 / \mathrm{RT})\left[\mathrm{kg} / \mathrm{m}^{2} \cdot \mathrm{s}\right]-(2)$

(2)炭素による分解反底：黒鉛るつぼを用いて, $\mathrm{Na}_{2} \mathrm{CO}_{3}(1)+$ $2 \mathrm{C}(\mathrm{s}) \rightarrow 2 \mathrm{Na}(\mathrm{g})+3 \mathrm{CO}(\mathrm{g}), \mathrm{Na}_{2} \mathrm{O}($ in $f \mid u x)+\mathrm{C}(\mathrm{s}) \rightarrow \mathrm{CO}(\mathrm{g})$ の反応飞 よる $\mathrm{Na}_{2} \mathrm{CO}_{3}, \mathrm{Na}_{2} \mathrm{O}-\mathrm{SiO}_{2} \mathrm{flu}$ 化の反応速度 $\mathrm{r}\left[\mathrm{mol} / \mathrm{m}^{2}\right.$.s $]$ を求めた。 この結果をFig.3（実線）および(3),(4)式に示す.

$\mathrm{Na}_{2} \mathrm{CO}_{3}: r=1.30 \times 10^{10} \exp (-74300 / \mathrm{RT})\left[\mathrm{molNa} \mathrm{CO}_{3} / \mathrm{m}^{2} . \mathrm{s}\right]-(3)$ $\mathrm{Na}_{2} 0-\mathrm{SiO}_{2}(B=1): \mathrm{r}=1.26 \times 10^{4} \exp (-49500 / \mathrm{RT})\left[\mathrm{mol} \mathrm{Na} 20 / \mathrm{m}^{2} \cdot \mathrm{s}\right](4)$

一方, 溶鉄中炭素 $(\underline{C})$ と $B=1$ の $\mathrm{Na}_{2} 0-\mathrm{SiO}_{2}$ fluxの反応速度は, Fig.3 中に破線で示すように, 温度依存性は小さかった。

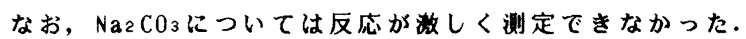

(3)溶鉄との反応： $\mathrm{Na}_{2} 0-\mathrm{SiO}_{2}$ fluxの $\mathrm{Na}_{2} \mathrm{O} / \mathrm{SiO} \mathrm{S}_{2}$ 比（B)を 1 から 2 まで変えてフラックス中のNa20 䇱度を增すと, 生成されたス

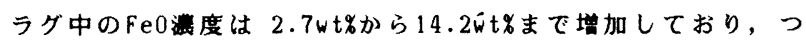
きの反応が生じていることが磼かめられた.

$$
\mathrm{Na}_{2} \mathrm{O}(\mathrm{free} \text { in } \mathrm{f} \mid \mathrm{ux})+\mathrm{Fe}(1) \rightarrow 2 \mathrm{Na}(g)+\mathrm{Fe} 0(\mathrm{~s} \mid \mathrm{ag})
$$

〈参考文献〉1）中村ら；鉄と鉷，66(1980),p.2023

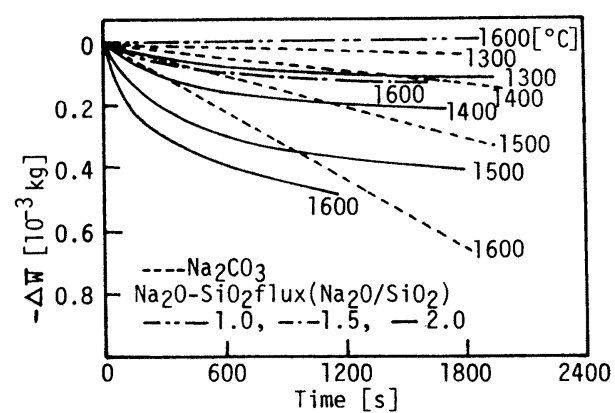

Fig.1. Weight loss behaviors of $\mathrm{Na}_{2} \mathrm{CO}_{3}$ and $\mathrm{Na}_{2} \mathrm{O}-\mathrm{SiO}_{2}$ fluxes.

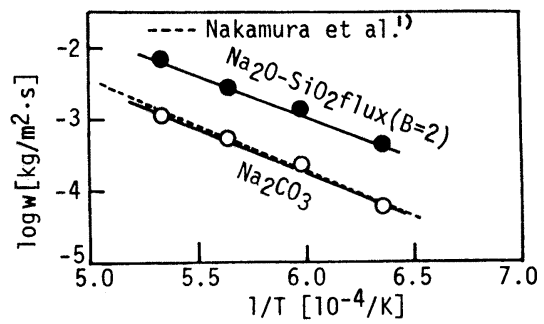

Fig.2. Relation between $\log w$ and $1 / T$.

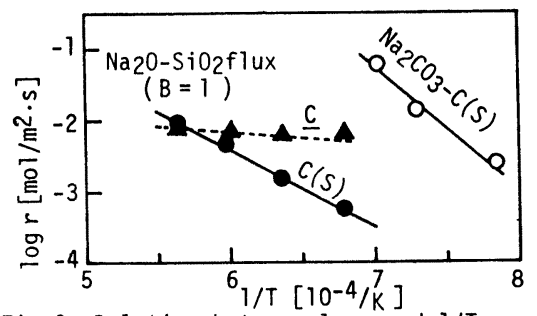

Fig.3. Relation between logr and $1 / T$. 
（298） $\quad \mathrm{Na}_{2} \mathrm{O}-\mathrm{CaO}-\mathrm{S} \mathrm{i}_{2}$ 乐フラツクスによる溶鉄の

\section{同時脱 り人脱硫}

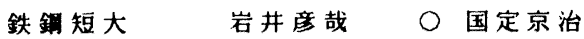

\section{1. 緒 言}

高級鐵の生産增加にともない，合理的に銿中のりんお よび硫黄湿度をごく低いレベルまで低下させるブロセス が検討されている. 本研究は, $\mathrm{Na}_{2} 0-\mathrm{Si} 02$ 系フラックス による脱りん脱硫に関する研究の一環として, Na20-Ca0Si 02 系フラックスによる溶鉄の同時脱りん脱硫実験を行 い, 脱りん脱硫に及ほす $\mathrm{Ca} 0$ の影整について調查した。 2. 実鈋方 法

高周波溶解妒を用い, Ar 等囲気下, $1600^{\circ} \mathrm{C}$ で実呀した。 内径 $70 \mathrm{~mm}$ 高さ $160 \mathrm{~mm}$ のマグネシアるつほ中の溶融鉄合金試 料 $(0.02 \sim 0.12 \mathrm{wt} \% \mathrm{P}, 0.006 \sim 0.15 \mathrm{wt} \% \mathrm{~S}) 1.2 \mathrm{kgR} \mathrm{Na} 20(34$ $\sim 54 w \mathrm{t} \%)-\mathrm{Ca} 0(13 \sim 33 w \mathrm{t} \%)-\mathrm{Si} 02(33 w \mathrm{t} \%)$ フラックス $0.1 \mathrm{~kg}$ $(0.01 \mathrm{~kg} \times 10$ 個)を実験初期の $300 \mathrm{sec}$ 間に添加し, 脱りん 脱硫を行った。

\section{3. 実殹結果および考察}

フラックスの $\mathrm{Na}_{2} 0 / \mathrm{CaO}$ 重量比が $34 / 33 ， 54 / 13$ と異な る $\mathrm{Na}_{2} 0-\mathrm{CaO}-\mathrm{SiO}_{2}$ 系フラックス（ $\mathrm{SiO}_{2}$ 量は $33 \mathrm{wt} \%$ 一定）を 用いた場合の $\underline{P}, \underline{S}$ 湍度の経時変化をFig. 1 に示す。 この比が高いフラックスの場合には良好な脱りん脱硫同時 反応が起こっている.

同時脱りん脱硫に及ぼすフラックスの $\mathrm{Na} 20 / \mathrm{Ca} 0$ 比の影 幚を Fig. 2 に示す.ここで, $\mathrm{Na}_{2} 0 / \mathrm{CaO}$ 比は $2 \mathrm{Na}_{2} 0 . \mathrm{Si} 0$ を $2 \mathrm{CaO} . \mathrm{SiO} 2$ で置換することにより調整した。フラックス 中の $\mathrm{Ca} 0$ 量が增すと，脱りん率はわずかに低下する程度で 著しい変化を示さないが，脱硫率は急湤に低下しており， 本系のフラックスによって効事よく同時脱りん脱硫を行う ためには，この比を高く設定する必要があることが明かで ある。

一方，得られたりんおよび硫黄の分配について検討した 結果をそれぞ Figs．3，4に示す．本結果におけるりん 分配比およびSulfide Capacity Cs は, Naz0(- $\mathrm{Ca} 0)$ 系フラ ックスによる単独の脱りんおよび脱硫結果 ${ }^{1}{ }^{2}$ )と比较して 低い值を示した。

\section{〈参考文献〉}

1) K.Kunisada et a|.: Trans.|S|J,27,(1987),p.332

2) H. Iwai et a|.: Trans.|S|J,27,(1987),B-97

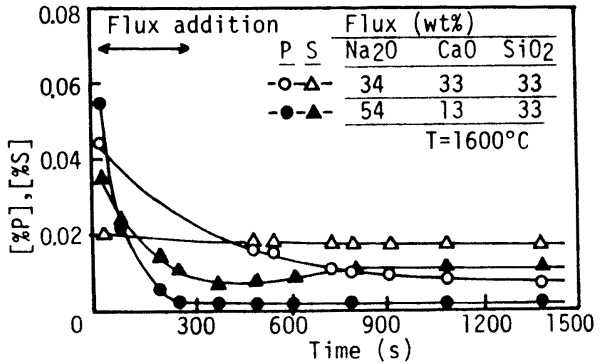

Fig.1. Variations of $\underline{P}$ and $\underline{S}$ with time.

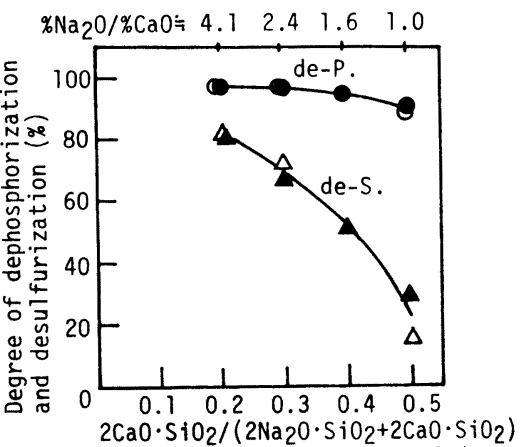

Fig. 2 Effect of $\mathrm{CaO}$ on the degree of dephosphorization and desulfurization.

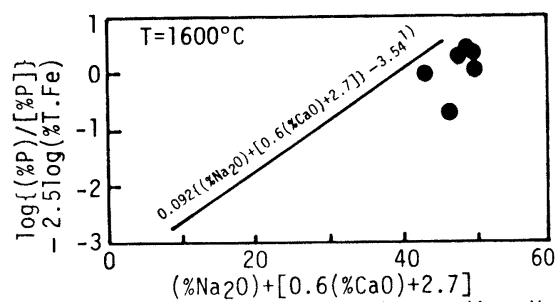

Fig.3. Relation between phosphorus distribution ratio and $\left(\% \mathrm{Na}_{2} \mathrm{O}\right)+[0.6(\% \mathrm{CaO})+2.7]$

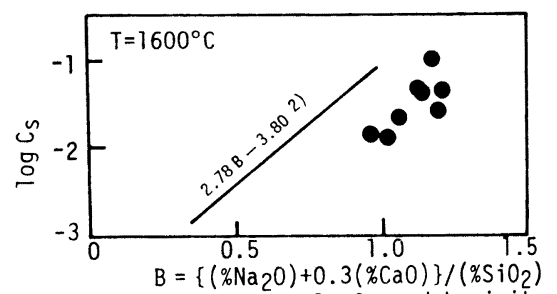

Fig.4. Relation between $\log _{S}$ and basicity. 
名古屋大学大学院 ○大谷美智浩 潘 偉

名古屋大学工学部佐野正道 平沢政広 森 一美

1. 腥 言 Fe0 を含むスラグによる高炭素濃度溶鉄の脱りんにおいては、スラグーメタル界面にお いて脱炭反応によるC0気泡の生成を伴うため、界面酸素ポテンシャルがその影響を受け、非常に複雑で ある。そのため、この反応系の速度論的研究はあまり行われていない。1'本研究では、高炭素濃度溶鉄 中及び $\mathrm{Fe} 0$ を含む $\mathrm{Li}_{2} 0-\mathrm{Ca} 0-\mathrm{SiO}_{2}$ 系スラグ中のりん濃度を種々变化させて実験を行い、メ夕ル中及び スラグ中のりん濃度があまり変化しない実験条件下におけるりん分配比とスラグ中Fe 0 濃度の関係を調 ヘ、高炭素濃度溶鉄の脱りん反応を速度論的に解明するための基礎的資料を得ることを目的とした。 2. 実 験 SiC 抵抗炉を用い、 $1300^{\circ} \mathrm{C} 、 A r$ 雾囲気下でアルミナるつば（内径 $40 \mathrm{~mm}$ 、高さ $250 \mathrm{~mm}$ ）中 に所定P 濃度のFe-C-P合金及び $\mathrm{Li}_{2} \mathrm{O}-\mathrm{CaO}-\mathrm{SiO}_{2}$ 系スラグ $\left(\mathrm{Li}_{2} \mathrm{O}\right.$ $\left.20.5 \% 、 \mathrm{CaO} 38.4 \% 、 \mathrm{SiO}_{2} 41.1 \%\right)$ を溶解後、りん酸カルシウム と Feo を添加して実験を開始した。メタル、スラグ質量は各々 $300 \mathrm{~g}, 35 \sim 39 \mathrm{~g}$ 、各成分の初濃度として、 $[\% \mathrm{C}]_{0}=\sim 4.4,[\% \mathrm{P}]_{0}=$ $0.002 \sim 0.083 、(\% \mathrm{P})_{0}=0.52 \sim 1.39 、(\% \mathrm{Fe} 0)_{0}=10 \sim 20.5$ と変化さ せた。実験中メタル・スラグ浴はアルミ十擋拌棒により回転数200 $r p m$ で擋拌した。メタル、スラグ試料を適宜採取し、メタル中P， C、スラグ中 $\mathrm{P}, \mathrm{Fe} 0$ 濃度の経時変化を求めた。また、C 0 反応によ るスラグフォーミング高さ剈を测定した。

3. 実験結果と考察 Fig.1にメタル、スラグ中りん濃度の時 間変化が比較的小さい実験における各反応成分濃度及びスラグフ オーミング高さの経時変化を示す。この実験ではメタル、スラグ 中りん濃度と界面りん濃度の差は非常に小さいと考えられ、平衡 に近い状態を保ちつつ、 $\mathrm{Fe} 0$ 濃度の減少とともに復りんが若干進 行する。図より脱炭反応によってメタル中炭素濃度及びスラグ中 $\mathrm{Fe} 0$ 濃度はかなり減少する事がわかる。静止スラク層厚さ $1 \mathrm{~cm} に$ 対してフォーミングによりスラグ層厚さは7〜9 cmに増加した。

Fig. 2に、種々の実験条件下におけるりん分配比 $L_{P}=(\% P) /[\% P]$ とスラグ中 $\mathrm{Fe} 0$ 濃度の関係を示す。初期の $\mathrm{L}_{\mathrm{p}}$ が非常に大きい時に は、時間の経過とともにFe0 濃度が減少し、復りんする。一方、 初期の $L_{\mathrm{p}}$ が小さいときにはFe0 濃度が減少しても $\mathrm{L}_{\mathrm{p}}$ が增加し、脱 クんが進行する。Fig. 1 に示した実験の初期のL ることがわかる。Fig. 2において点線で曲んだ部分はりん反応が 準平衡的に推移していると考えられる場合の $\mathrm{L}_{\mathrm{p}}$ と FeO 濃度の関係 を示す。

以上の実験結果に基づいて高炭素濃度溶鉄の脱りん、界面酸素 ポテンシャルについて熱力学的考察を加える。

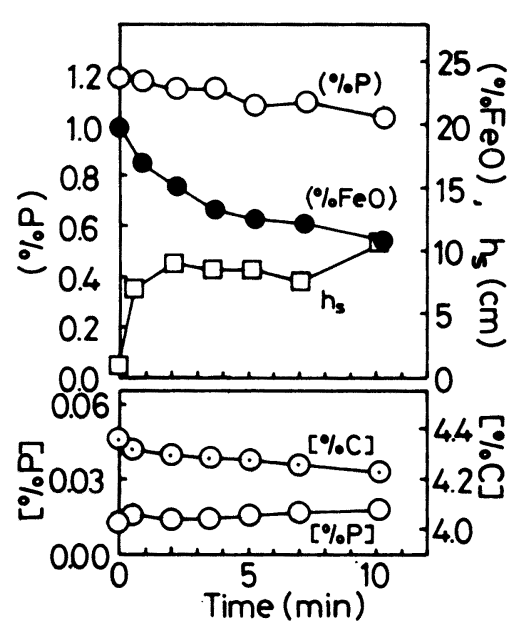

Fig. 1 changes in metal- and slagcompositions and the slag foaming hight with time

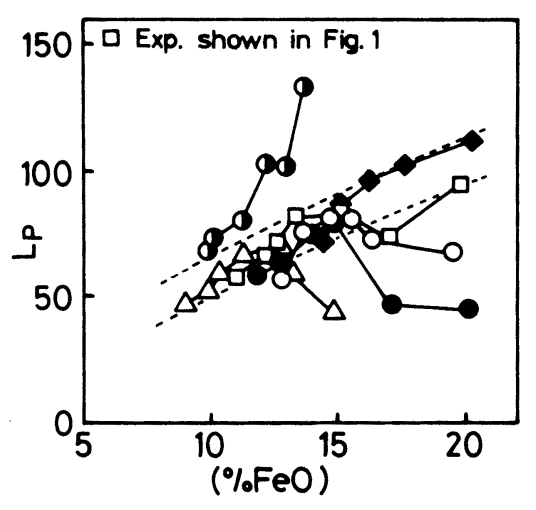

Fig. $2 L_{p} v s . \quad(\% \mathrm{Fe} 0)$ 文献 1)Ohguchi et al.: Ironmaking Steelmaking, 11(1984)p. 202 
（300）酸化マンガンを含むフランクスによる溶敛の脱りん速底

\section{1. 緹言}

九州大学大学院

九州大学工部
○前田満

筷崎信也森克已

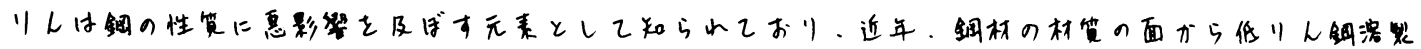
挍街を確立することが要求されている。

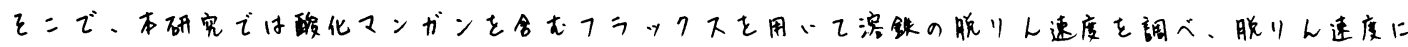

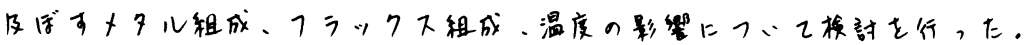

2. 实䢁方法

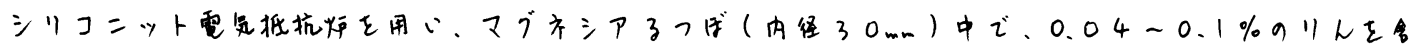

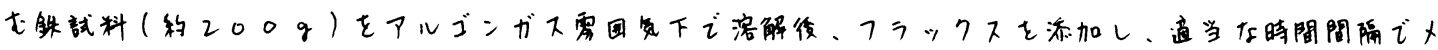

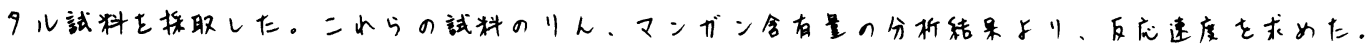

棌加したフラックスは、 $\mathrm{CaO}-\mathrm{CaF}_{2}-\mathrm{Al}_{2} \mathrm{O}_{3}$ 系に酸化就とし

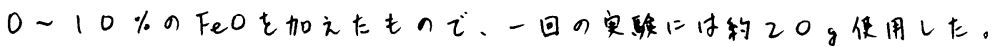

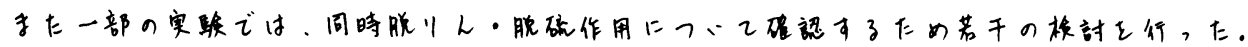

\section{3. 实騅转果}

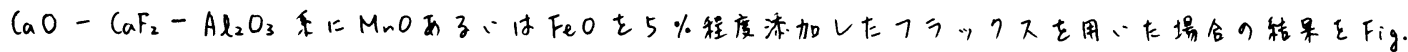

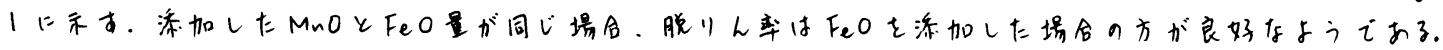

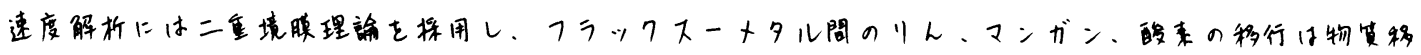

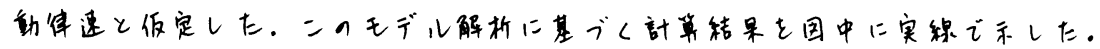

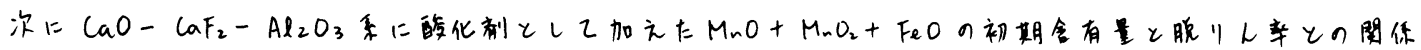

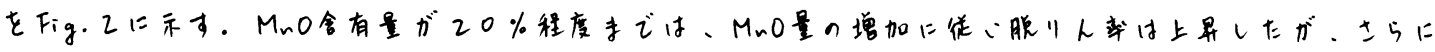

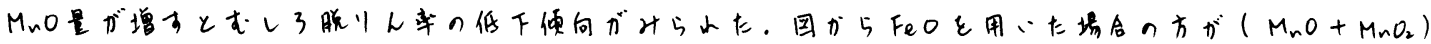

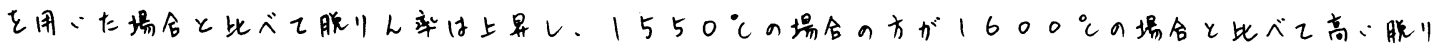

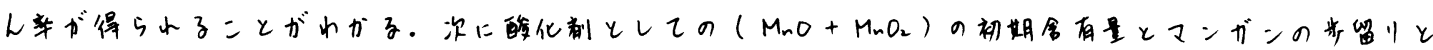

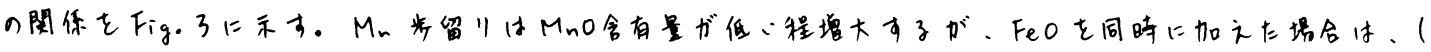
$\left.\mathrm{Mn}_{n} \mathrm{O}+\mathrm{M}_{n} \mathrm{O}_{2}\right)$ 单独の䭪合と比艺药の步留りは低下した。

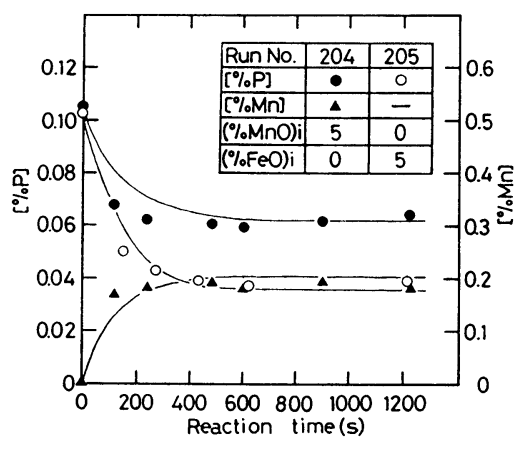

Fig.l Effect of Kind of oxidant on the Fig. 2 The relutionship between the dephosphorization of molten metal. $\left(50 \mathrm{CaO}-35 \mathrm{CaF}_{2}-10 \mathrm{Al}_{2} \mathrm{O}_{3}\right)$

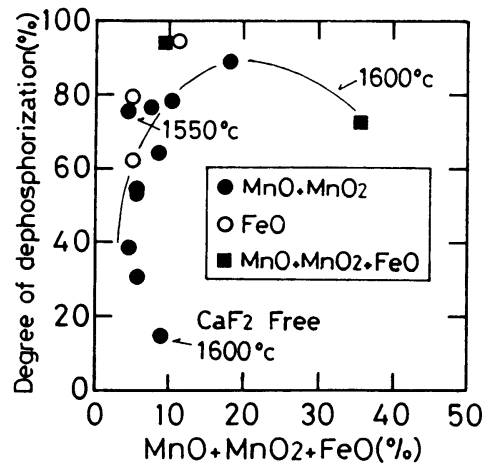
degree of dephosphorization and the initial content of oxidant.

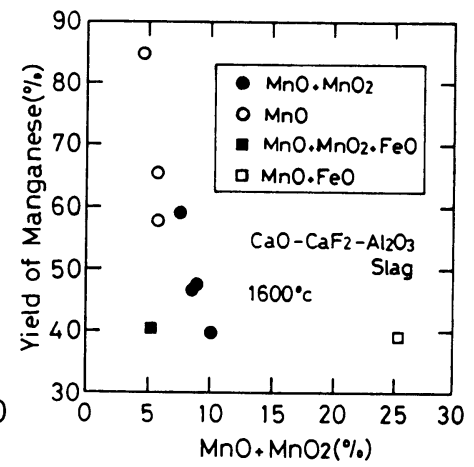

Fig. 3 The relationship between the yield of manganese and initial content of manganese oxide. 